\author{
UNIVERSIDADE DE SÃO PAULO \\ FACULDADE DE FILOSOFIA, LETRAS E CIÊNCIAS HUMANAS \\ DEPARTAMENTO DE FILOSOFIA \\ PROGRAMA DE PÓS-GRADUAÇÃO EM FILOSOFIA
}

Pedro Moreira Graça

O Muro de Fora: Matrizes e desenvolvimentos da pintura e escritura mural paulistana 


\author{
UNIVERSIDADE DE SÃO PAULO \\ FACULDADE DE FILOSOFIA, LETRAS E CIÊNCIAS HUMANAS \\ DEPARTAMENTO DE FILOSOFIA \\ PROGRAMA DE PÓS-GRADUAÇÃO EM FILOSOFIA
}

\title{
O Muro de Fora: Matrizes e desenvolvimentos da pintura e escritura mural paulistana
}

\begin{abstract}
PEDRO MOREIRA GRAÇA
Dissertação apresentada ao Programa de Pós-Graduação em Filosofia do Departamento de Filosofia da Faculdade de Filosofia, Letras e Ciências Humanas da Universidade de São Paulo, para a obtenção do título de Mestre em Filosofia.
\end{abstract}

Orientador: Prof. Dr. Leon Kossovitch

\section{São Paulo}

2017 
Aos meus pais: Sílvia e Isidro, pelo exemplo moral e apoio irrestrito. 
GRAÇA, P. M. O Muro de Fora: Matrizes e desenvolvimentos da pintura e escritura mural paulistana. Dissertação apresentada ao Programa de Pós-Graduação em Filosofia do Departamento de Filosofia da Faculdade de Filosofia, Letras e Ciências Humanas da Universidade de São Paulo, para a obtenção do título de Mestre em Filosofia.

Aprovado em:

Banca Examinadora:

Prof. Dr. Instituição:

Julgamento:

Assinatura:

Prof. Dr.

Instituição:

Julgamento:

Assinatura:

Prof. Dr.

Instituição:

Julgamento:

Assinatura: 


\section{RESUMO}

GRAÇA, P. M. O Muro de Fora: Matrizes e Desenvolvimentos da Pintura e Escritura Mural Paulistana. Dissertação (Mestrado). Faculdade de Filosofia, Letras e Ciências Humanas, Universidade de São Paulo, 2017.

A multiplicidade das pinturas e escrituras murais na cidade de São Paulo desde os anos 1970 até os dias de hoje não evidencia uma ordem ou hierarquias que permitam separar uma assinatura rabiscada com um giz de cera em um muro de uma pintura de várias cores com tinta spray, pichação enquanto mero vandalismo do graffiti enquanto pintura mural elaborada. $O$ que $\mathrm{o}$ presente trabalho busca mostrar é que cada um dos grandes grupos que compõe as diversas vertentes de pintura e escritura mural praticadas na cidade de São Paulo tem suas próprias matrizes, exemplos e muitas vezes regras estritas de procedimento e valoração interna. A busca por uma separação entre grandes grupos se dá na primeira parte da dissertação, ao sugerir uma história em ordem cronológica dos maiores grupos que se estabeleceram durante o final da década de 1970 e toda a década de 1980, traçando referências e pontos de contato desses grupos com outras práticas análogas no resto do mundo. A segunda parte do trabalho busca estabelecer alguns conceitos que podem ajudar a entender o desenvolvimento de alguns desses grupos e indivíduos. Em seguida o trabalho de alguns praticantes será analisado a fim de propor uma quebra com a linhagem formadora inicial desses mesmos.

Palavras-chave: Estética; Arte; Graffiti; Pichação; Arte Urbana 


\begin{abstract}
GRAÇA, P. M. The Outside Wall: Origins and Development of São Paulo's Mural Painting and Writing. Dissertação (Mestrado). Faculdade de Filosofia, Letras e Ciências Humanas, Universidade de São Paulo, 2017.

The multiplicity of mural paintings and writings practiced in the city of São Paulo, starting in the 1970's until today, could elude a certain order or hierarchies that could allow the distinction between a scribble made with crayon on a wall or a painting made with various spray paint colors, between tagging (often called pichação in Brazil) and graffiti (usually the name given to more elaborate mural paintings). What this work tries to achieve is to show that every major group that forms the different strands of mural painting and writing practiced in the city of São Paulo has its own roots, visual examples, and oftentimes strict rules of proceeding and internal valuation. The search for the separation of these groups will be presented in the first part of the dissertation, which suggests a chronological story of the main groups that were established during the end of the 1970's and throughout the 1980's in São Paulo, tracing the main references and points of contact between these groups and its analogue practices around the world. The second part is concerned with presenting certain concepts that try to help and understand the development of some of those groups and individuals. Following, the work of certain particular individuals will be analysed in order to propose a certain break from the formative lineage of these practitioners.
\end{abstract}

Keywords: Aesthetics, Art, Graffiti, Pichação, Street Art. 


\section{Sumário}

Introdução

$1 \quad$ O surgimento dos grupos paulistanos 10

$\begin{array}{lll}1.1 & \text { As gerações setenta } & 10\end{array}$

$\begin{array}{lll}1.1 .1 & \text { Pichação poética } & 10\end{array}$

$\begin{array}{lll}1.1 .2 & \text { O graffiti paulistano primeiro } & 16\end{array}$

$\begin{array}{lll}1.1 .3 & \text { A mão livre } & 22\end{array}$

$1.2 \quad$ graffiti de matriz nova-iorquina 25

1.2.1 Os elementos de um graffiti nova-iorquino 29

1.2.2 Graffiti no japão em $2016 \quad 31$

1.2.3 A novidade brasileira 33

$\begin{array}{lll}1.3 & \text { O Pixo } & 35\end{array}$

1.3.1 Pichação paulistana 35

1.3.2 Pichação x Pixo 38

$\begin{array}{lll}\text { 1.3.3 Os pioneiros do Pixo } & 39\end{array}$

1.3.4 Pixo x Xarpi 43

$2 \quad$ A dinâmica nos grupos paulistanos 45

$2.1 \quad$ Agonismo e destruição $\quad 45$

2.1.1 O suporte móvel 48

2.1.2 Destruição 50

2.1.3 Whip e a cidade limpa 52

2.1.4 Transgressão, valor e destruição 57

$\begin{array}{lll}2.2 & & 60\end{array}$

$\begin{array}{lll}2.2 .1 & \text { Salmos: letra e personagem } & 61\end{array}$

2.2.2 O procedimento do flop 65

$\begin{array}{lll}2.2 .3 & \text { Nunca } & 69\end{array}$

$\begin{array}{lll}2.2 .4 & \text { A xilogravura em spray } & 71\end{array}$

$\begin{array}{lll}2.2 .5 & \text { Os gêmeos } & 73\end{array}$

$\begin{array}{lll}2.2 .6 & \text { Kobra } & 75\end{array}$

$\begin{array}{ll}\text { Conclusão } & 77\end{array}$

$\begin{array}{ll}\text { Bibliografia } & 79\end{array}$

$\begin{array}{ll}\text { Anexos } & 80\end{array}$ 


\section{Introdução}

Descendo a rua São Joaquim, a partir da estação de metrô do mesmo nome, na contramão dos carros que sobem no sentido da rua Vergueiro, é possível ver todo tipo de pichações nos muros dos prédios da região. Assinaturas estilizadas feitas com caneta marcadora de ponta chanfrada, grandes letreiros arredondados feitos em duas cores de spray e rabiscos ininteligíveis feitos às pressas com um giz de cera encaram de frente a Grande Loja Maçônica do Estado de São Paulo e cobrem os tapumes do ainda por inaugurar Museu Manabu Mabe. Pintando as superfícies com todas as cores que um spray, caneta ou giz de cera podem marcar. Este é o material de mais fácil acesso para a iniciação no mundo do pixo ${ }^{1}$ e do graffiti.

A proximidade da escola estadual Presidente Roosevelt pode ajudar na interpretação dos muros da rua cobertos dessa humilde forma de inscrição ilegal. Um moleque enche o bolso de giz e sai para a rua, achando uma superfície áspera o bastante para aceitar o sedimento colorido da parafina, pega um giz da cor que mais contraste com o suporte escolhido, olha para os dois lados e em poucos segundos vai embora, como se nada tivesse acontecido. O muro agora guarda seu apelido e, por mais que quem passe na rua não consiga ler o que está escrito, ele e os seus sabem. O graffiti praticado na cidade de São Paulo desde o final da década de 1970 até hoje quase sempre estará preso a esta dicotomia, entre uma produção voltada para os seus próprios praticantes e uma pintura que visa à aceitação do público geral.

Esta pesquisa tem dois objetivos principais; estudar os principais grupos que fazem parte do que foi e do que ainda é pintado nos muros da cidade de São Paulo e apresentar alguns conceitos que tentam enriquecer o entendimento de como esses grupos se desenvolveram a partir de suas matrizes. Este segundo objetivo vai abordar alguns exemplos de artistas que tiveram a sua formação não em uma instituição formal de artes, mas na rica e por vezes limitadora tradição do graffiti

\footnotetext{
${ }^{1}$ A grafia "Pixo" em lugar da correta "Pichação", será definida no decorrer da dissertação.
} 
praticado no Brasil. A pretensão não é explicar absolutamente todos os tipos de pinturas, escrituras e outros tipos de marcas deixadas (anonimamente ou não) nas paredes públicas da cidade de São Paulo, mas identificar quais foram os principais grupos que deram as bases para as práticas mais reconhecidas.

A primeira parte desta pesquisa busca contar cronologicamente a história dos principais grupos que a partir dos anos 1970 marcaram os muros da cidade com pinturas e escrituras -muitas vezes enigmáticas. Como se verá, o critério que separa esses primeiros grupos dos posteriores, iniciados por volta de meados dos anos 1980, se dá principalmente pela introdução do estilo americano de graffiti. Com base em entrevistas, conversas, referências bibliográficas e análises visuais, ficará ao critério do leitor da pesquisa que motivos apresentados para a separação entre os grupos se justificam. Porém, é importante lembrar que, de maneira geral, os próprios praticantes enxergam estas separações.

A segunda parte desta pesquisa apresenta alguns conceitos-chave que buscam entender as dinâmicas do graffiti paulistano. Apresentando os conceitos de agonismo e destruição como importantes forças formadoras da técnica e regras de procedimento do "Graffiti de matriz nova-iorquina" e da "Pichação paulistana", será apresentada uma chave para o desenvolvimento técnico que ordena a produção local. A partir dessas conceituações define-se um segundo movimento, chamado individuação, que busca identificar no exemplo de alguns grafiteiros o processo pelo qual muitos destes se afastaram dos, por vezes limitadores, exemplos e regras de procedimento da pintura do "Graffiti internacional". Esta direção para um trabalho autoral, começada nos anos 1990, é o movimento que projeta a pintura mural como praticada no Brasil para o resto do mundo. 


\section{0 surgimento dos grupos paulistanos}

\subsection{As gerações setenta}

\subsubsection{Pichação Poética}

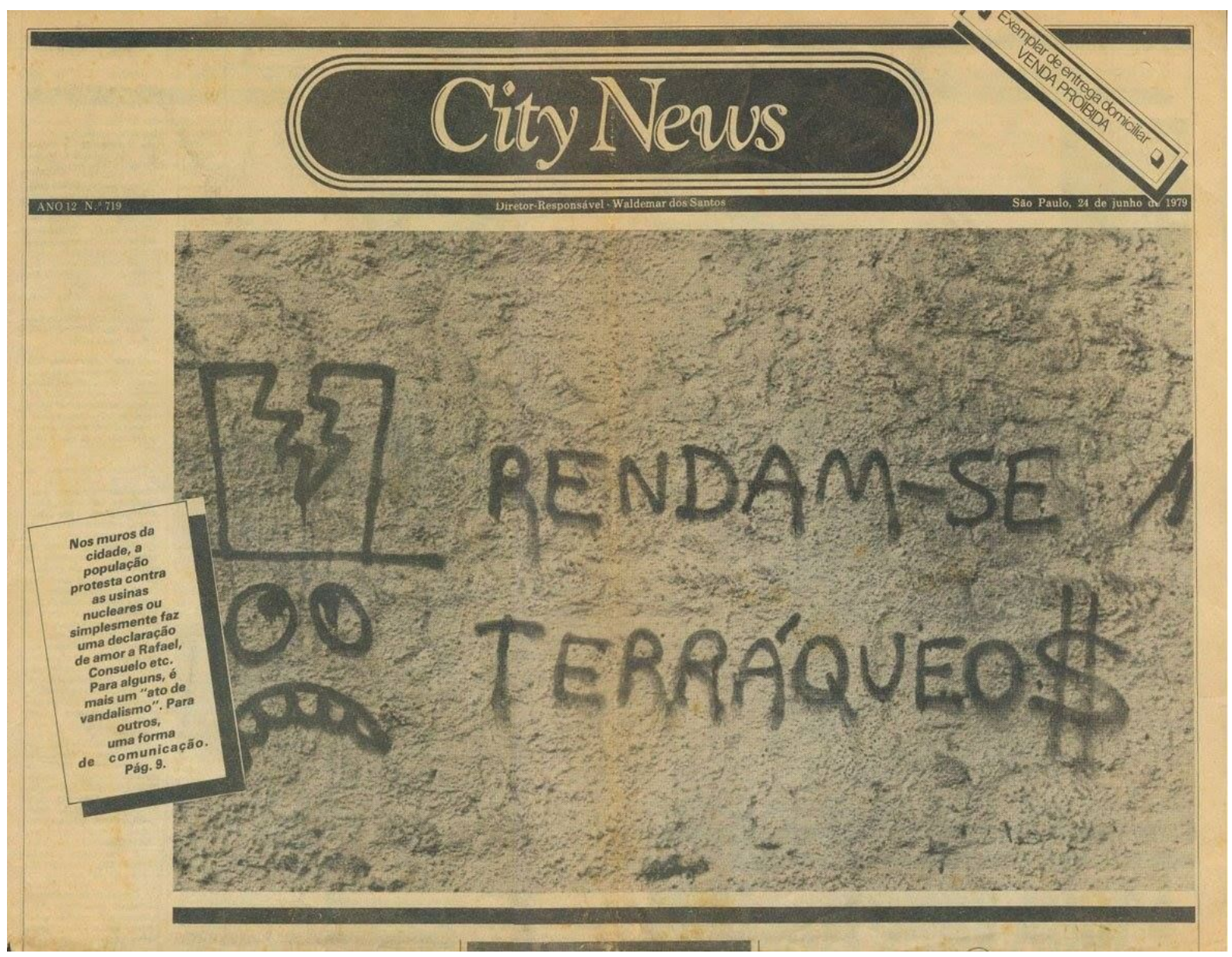

Fig 1. Capa do Jornal City News de 24 de Junho de 1979.

“Celacanto provoca maremoto não quer dizer absolutamente nada além do que está escrito, não tem nenhum outro sentido, como muitos tentaram explicar". Lemos na matéria publicada em 20/07/1978 no Jornal do Brasil que revela a identidade do até então anônimo pichador que escrevia paredes, pedras e muros com essa enigmática frase desde 1977 no Rio de Janeiro. Em contraste com as pichações políticas que tomavam as ruas do final da década anterior, nos anos setenta começaram a aparecer inscrições que não pareciam ter um sentido tão 
direto quanto a pichação "ABAIXO A DITADURA" indicava. Não que o próprio ato de escrever ilegalmente em um muro voltado para o espaço público não fosse por si uma afronta às instituições, mas o mistério de seu objetivo atiçou a imaginação de quem prestava atenção nessas pichações.

"Elas gravam um burburinho, de que eram pichações contra a ditadura. Não sabíamos quem as fazia; pareciam códigos secretos, quer dizer, a gente sabia que o celacanto era citação do National kid. ${ }^{2}$ Então eram códigos antiditatoriais pop". ${ }^{3}$

Diz a fala de Alex Antunes, um dos integrantes do grupo que atacava os muros de São Paulo com a pichação RENDAM-SE TERRÁQUEO\$, durante o ano de 1979 e começo de 1980, quando questionado sobre o impacto que as primeiras pichações que ele viu causou e que, além de CELACANTO PROVOCA MAREMOTO incluía outra misteriosa frase, CÃO FILA KM 26 (em algumas fontes referido como KM 22).

"No Brasil, além das frases de protesto, surgiram outras bem-humoradas e enigmáticas, como por exemplo: CELACANTO PROVOCA MAREMOTO, referente ao monstro pré-histórico do seriado japonês National Kid, e CÃO FILA KM 22, que dizia respeito a um criador da raça de cães...." ${ }^{4}$ Indica Celso Gitahy em seu livro O que é Graffiti?. ${ }^{5}$

Estas duas pichações, o CELACANTO no Rio de Janeiro e o CÃO FILA em São Paulo, embora vindas de lugares distintos - um estudante de física e um criador de cães- apresentaram, cada qual ao seu modo, uma possibilidade nova até então não presente nos muros da cidade de São Paulo. A escrita mural que não apresenta uma mensagem clara, que não se parece sequer com uma assinatura. $O$ que se seguiu na cidade de São Paulo foi uma proliferação de frases sem sentido aparente; TE AMEI, HOJE USO AGENDA - HENDRIX, MANDRAKE, MANDRIX - GONHA MÓ BREU - MARIA CLARA, QUERO A GEMA - VEJO UM VULTO NA JANELA ${ }^{6}$ -

\footnotetext{
${ }^{2}$ Seriado Japonês de super-herói que fez muito sucesso durante a década de 1960 no Brasil.

${ }^{3}$ Alex Antunes em entrevista para esta pesquisa.

${ }^{4}$ Idem.

${ }^{5}$ GITAHY, Celso. O que é Graffiti. São Paulo: Brasiliense, 1999, $3^{a}$ reimpressão 2012. Pg. 21.

${ }^{6}$ Esta pichação servia como propaganda para uma peça de teatro, segundo Alex Antunes em entrevista para esta pesquisa, mas encaixava bem dentro do conjunto das outras pichações para um observador comum.
} 
RENDAM-SE TERRÁQUEO\$ - XÔ URUBU - É DIFÍCIL - AH, BEIJE-ME - Entre diversas outras, centralizadas especialmente entre a zona oeste da cidade de São Paulo e os arredores da Cidade Universitária de São Paulo, onde estudava grande parte dos pichadores dessa prática, que ficou conhecida como "Pichação poética" ou, segundo Cristina Fonseca em seu livro A Poesia do Acaso, "Sprayações".

Quando perguntado sobre a validade do termo "Pichações poéticas" para designar a ação das pichações que se fazia em São Paulo ao final da década de 1970, Alex Antunes responde:

"Num sentido amplo de 'poético', faz. Não porque fôssemos leitores de poesia. Creio que nós quatro, apesar de dois de nós arriscarmos uns versinhos, achávamos poesia um treco em geral bastante pedante. Éramos mais chegados em letras de música. Por exemplo, não faria sentido puxar uma relação com a poesia neoconcretista (cito isso porque você disse que há quem o faça). ${ }^{7}$ Mas o poético entra aí no sentido da poética contracultural, do slogan desconstrutivo, disparador de insights. Acho que isso estava sincronizado com a nossa apropriação dos muros, que em si mesma era um tipo de ruído, de provocação não-programática, de 'ocupação psíquica"'. ${ }^{8}$

A época mais intensa das pichações poéticas teve curta duração, como o próprio Alex Antunes diz quando conta da atividade do grupo que fazia parte, o RENDAM-SE TERRÁQUEO\$:

“Celso 'Minho K' Pucci, Renato Cosentino, Paulo Zocchi e eu. Éramos quatro, a lotação total de nosso único carro, uma belina do pai do Zocchi. Basicamente o Zocchi era o motorista e nós outros três nos alternávamos na vigilância e na pichação. Nunca fomos pegos. Nossa área de intervenção mais frequente era entre as imediações do aeroporto de congonhas, onde morávamos três de nós, e as imediações da usp, onde estudávamos e morava o quarto. Que eu saiba, as imediações da usp eram então o mais frequente local de pichações da cidade". ${ }^{9}$

A novidade e diferença das "Pichações poéticas" para com as ondas posteriores de pichações e graffiti na cidade de São Paulo, mais do que sua curta duração ou pouca cobertura de espaço da cidade, é o que ressalta essa prática das outras. A proximidade de época e possivelmente co-autoria de membros de um

\footnotetext{
${ }^{7}$ Grande parte do esforço aparente do livro "Poesia do Acaso (na transversal da cidade) de Cristina Fonseca aponta para esta relação.

${ }^{8}$ Alex Antunes em entrevista para esta pesquisa.

${ }^{9}$ Alex Antunes em entrevista para esta pesquisa.
} 
grupo assim como na primeira onda de graffiti na cidade de São Paulo -anteriores à introdução do estilo americano de graffiti em São Paulo e da proliferação da "Pichação paulistana" (também conhecida como "Pixo"), tende a identificar as duas práticas, as "Pichações poéticas" e o graffiti paulistano da primeira onda. Sobre essa possível identificação unificadora, Alex Antunes diz:

"Acho que tem uma convergência mais com o pixo ${ }^{10}$, nesse sentido de apropriação radical, ruidosa, não-decorativa do muro. E menos com o graffiti da geração estêncil que é imediatamente posterior à nossa, porque essa já tem uma consciência de street art, que nós não tínhamos. Sei que começamos antes do pessoal do estêncil porque certamente teríamos pensado em usar essa técnica, se soubéssemos dela. Num momento posterior, pensávamos na nossa música pós-punk de universitários em relação com o punk periférico raivoso. Não seria descabido dizer que temos uma relação similar com o pixo, apesar da não-simultaneidade. $O$ fato de termos brigado por estabelecer uma autoria pro "rendam-se" quando da polêmica da casa das rosas ${ }^{11}$, em 2002, reforça um pouco essa relação. É como se alguém que não é o buiu ${ }^{12}$ do pixo viesse dizer que é o buiu. O engraçado é que, na época, uma agência de publicidade criou um outdoor com a frase 'rendam-se terráqueos' (sem o cifrão no s final) pra vender uma massa de bolo, mas aí não tínhamos como reclamar". ${ }^{13}$

Segundo esta identificação da "Pichação poética" dos RENDAM-SE TERRÁQUEO\$ enquanto distinta dos graffiti posteriores, não seriam apenas relevantes as diferenças visuais do objeto escrito ou pintado no muro, mas também enquanto assinaturas enigmáticas anônimas, que não tinham necessariamente em um estilo de figurar a sua característica individualizante, além da própria mensagem (enigmática) da frase e sua repetição nos muros.

Existe um caminho teórico, uma trilha causal, que interpreta em termos gerais a matriz dos graffiti e pichações dos anos 1970 (e além) no Brasil a partir das pichações do Maio de 68 na França, passando -nesta ordem- pelos graffiti americanos da década de 1960 e 1970 em Nova lorque até desaguar em terras brasileiras. Grande parte do esforço de Cristina Fonseca em seu livro Poesia do Acaso (na transversal da Cidade) publicado em 1985, indica este caminho:

\footnotetext{
${ }^{10}$ A "Pichação paulistana" será tratada posteriormente no texto, inclusive o uso do termo "Pixo" ao invés de "Pichação" grafia estabelecida como correta na norma culta do português brasileiro.

${ }^{11}$ Houve uma polêmica sobre a exposição de 2002 na casa das rosas intitulada "RENDAM-SE TERRÁQUEOS" na qual Alberto Marscicano diz ser autor da frase "Rendam-se Terráqueos", como vê-se na matéria no Estado de São Paulo de 4 de março de 2002.

${ }^{12}$ Nome informal para menino que mora no morro.

${ }^{13}$ Alex Antunes em entrevista para esta pesquisa.
} 
"OS GRAFITES de MAIO de 68 restringiram-se ao redor e nos muros internos da SORBONNE, mas sua repercussão foi intensa. acabaram por influenciar, entre outras coisas, as inscrições dos METRÔS de NY em 1972 e mesmo as pichações brasileiras de 1979/1982". ${ }^{14}$

Perguntado sobre essa possível relação entre o Maio de 68 na França com a "Pichação poética", Alex Antunes diz:

"Pra mim faz sentido. Note, no final da década de 1970, na usp, havia uma contracultura em permanência, era um equivalente a 1971 na Europa e nos EUA. Na ECA havia um festival chamado Woodsteca e, apesar de ser uma brincadeira, não era uma brincadeira mordaz. Eu mesmo tinha um certo desespero em pensar que não teria a chance de viver um 1968; mal sabia que teríamos nosso próprio momento em meados dos 80 . Acho que o caráter de slogan provocador é herdeiro da época da contracultura clássica, sim; um 'HENDRIX MANDRAKE MANDRIX' praticamente afirma isso". ${ }^{15}$

Porém, se existe identificação da "Pichação Poética" com o Maio de 68 (ao menos, confirmadamente, por parte de um integrante dos RENDAM-SE TERRÁQUEO\$), seria feliz essa trilha causal entre o maio de 68 francês e as manifestações paulistanas do final da década de 1970? Talvez não com tanta clareza quanto a levantada por Cristina Fonseca quando diz: "que tivemos influência de MAIO de 68 na frança não há dúvida. das pichações dos METRÔS de NY também" ${ }^{16}$ As "Pichações poéticas" não parecem ter ligação matricial imediata nem com os graffiti americanos da década de 1970 nem com as pichações de maio de 68. As "Pichações poéticas" não tinham uma mensagem clara e abertamente política como as do Maio de 68. A identificação com o graffiti produzido em Nova lorque durante a década de 1970 também não parece tão interessante, além da diferença de estilo, os graffiti nova iorquinos geralmente se davam na forma de letreiros que compunham o nome do próprio praticante, acompanhado ou não -depois de certo desenvolvimento- de elementos figurativos e decorativos auxiliares (como será descrito no próximo capítulo). A "Pichação poética" embora muitas vezes pudesse apresentar elementos além da própria escrita, como a figura que acompanha o RENDAM-SE TERRÁQUEOS e a boca carnuda de Hudnilson Jr. em

\footnotetext{
${ }^{14}$ FONSECA, Cristina. Pg. 19.

${ }^{15}$ Alex Antunes em entrevista para esta pesquisa.

${ }^{16}$ FONSECA, Cristina. A Poesia do acaso, Pág. 72.
} 
sua pichação $A H, B E I J E-M E$, não tem as mesmas referências que os elementos figurativos que começaram a acompanhar os letreiros americanos. Em seguida e/ou concomitantemente com as "Pichações poéticas", começou a aparecer outro tipo de pintura mural na cidade de São Paulo, onde a figuração começa a se mostrar mais importante do que a palavra escrita. 


\subsubsection{O graffiti paulistano primeiro}

"Vinte e duas horas e vinte e sete minutos do dia 9 de março de 1979.

Um homem magro, cabeludo, trajando sobretudo escuro, atravessa a avenida Ipiranga empunhando nas mãos trêmulas uma lata de spray vermelho-fogo. Seu olhar atento avista um muro bem pintado de branco. Observa à sua volta e, supondo-se sozinho, tão rápido quanto o pensamento, surge naquele muro "Ah Ah Beije-me" ao lado de uma enorme boca aberta, carnuda, exposta, lembrando uma puta. Ao tampar a lata para deixar o local, olhando para os lados, leva um grande susto, pois, quase do nada, um homem pequeno e extremamente rápido já havia graffitado ao lado da bocarra uma intrigante botinha preta, de cano alto e salto agulha.

Quando o segundo dobrava sua máscara ${ }^{17}$ (molde vazado sobre o qual se aplica a tinta spray) é que percebeu a presença do primeiro. Entreolharam-se e falaram quase ao mesmo tempo: "Ah, então é você?" Nesse momento, acontece o que, num futuro próximo, viria a ser uma das mais fecundas identificações de propostas artísticas, uma sólida amizade entre dois dos mais apaixonantes artistas contemporâneos que esta cidade já produziu."

O encontro de Hudnilson Jr (escritor da frase "Ah Beije-me" e pintor da boca vermelha) e Alex Vallauri (pintor da botinha preta) mostra um pouco da mudança de foco que iria se acentuar durante os próximos anos no que cobriria os muros de São Paulo. Alex Vallauri posteriormente seria amplamente reconhecido como um dos precursores do graffiti paulistano -tendo a lei municipal número 13.903 de 4 de novembro de 2004, marcando o dia 27 de março como o dia municipal do graffiti, em memória do seu falecimento em 27 de março de 1987. Como indicado no livro Estética Marginal: Volume \#2, as botinhas de Vallauri parecem apresentar uma novidade nos muros da cidade.

“Em 1978 aparecem em São Paulo as botas pretas, bico fino, cano e salto alto pixadas nos muros, uma novidade para os habitantes da cidade, que até então conheciam somente as pichações poéticas e nada de desenhos com máscaras". ${ }^{19}$

Diferente do que ocorreu em Nova lorque, que teve o desenvolvimento inicial de seu graffiti a partir de letreiros e em seguida das figuras que os acompanhavam, o graffiti que viria a ser praticado ao final da década de 1970 e começo da década

\footnotetext{
17 O nome 'máscara' costuma ser usado com o mesmo sentido de 'estêncil', que foi o termo escolhido para esta pesquisa.

${ }^{18}$ GITAHY, Celso. $O$ que é Graffiti. São Paulo: Brasiliense, 1999, $3^{\text {a }}$ reimpressão 2012.Págs. 51 52.

${ }^{19}$ SZACHER, Allan (org.). Estética Marginal Volume 2. São Paulo, Zupi Editora, 2012. Pág. 35.
} 
de 1980 em São Paulo, anterior à introdução do "Estilo americano" (que se deu por volta de 1985 como ficará claro no próximo capítulo) era quase que inteiramente composto por figuras. O livro Estética Marginal: Volume \#2 apresenta um bom panorama de muitas das figuras de maior proeminência na época; Alex Vallauri, Carlos Matuck, Waldemar Zaidler, John Howard ${ }^{20}$, Rui Amaral, Maurício Villaça, o grupo Tupinãodá (que inclui: Zé Carratü, Alberto Lima, Carlos Delfino, Ciro Cozzolino, Jaime Prades), Celso Gitahy (artista e também autor do livro O que é Graffiti? usado como referência nesta pesquisa ), Julio Barreto... O que eles tinham como qualidade unificadora, além da maior preocupação com a variedade visual do que a "Pichação poética", era o fato de focarem na figura, além de não se identificarem com a produção americana de graffiti que viria a tomar o mundo de assalto em meados da década de 1980.

Alex Vallauri começou suas pinturas murais com pequenos estênceis, inicialmente figurando botas, luvas e a característica figura de um acrobata tirada do pintor francês Georges Seurat. Carlos Matuck, artista que durante o final da década de 1970 e começo de 1980 pintou junto com Alex Vallauri e Waldemar Zaidler (também conhecido como Gordo) os muros de São Paulo, descreve como era o feitio das máscaras que Alex Vallauri usava no começo de suas incursões ilegais pelas ruas de São Paulo:

"Cartão, sempre. Duplex. Porque o Vallauri começou usando capa de disco, como é famoso, como ele tinha um monte de LP 45 antigos na casa dele, provavelmente por causa do pai e da mãe. Eram feitos num cartão bem durinho, bem bom, inclusive determinava o tamanho do que ele fazia, porque ele pegava uma capa de LP 45 , que é um negócio quadradinho assim -e abria, e esse retângulo deu o tamanho daquele acrobata, deu o tamanho da pantera, deu o tamanho de vários trabalhos; da luva, da bota, todos são enquadráveis numa capa de disco dupla. Todos, perfeitamente, do tamanho certinho da capa". ${ }^{21}$

Antes de Alex Vallauri não parecia ser tão comum no Brasil, para a pintura mural, o uso da técnica do estêncil (máscara recortada em algum material rígido o bastante para sustentar sua própria estrutura e resistir ao jato de tinta do spray, na

\footnotetext{
${ }^{20}$ John Haward é um artista nascido nos Estados Unidos que começou a pintar nas ruas de São

Paulo, não trazendo portanto a prática do graffiti americano consigo.

${ }^{21}$ Entrevista dom Carlos Matuck, presente no anexo deste trabalho.
} 
qual as áreas vazadas permitem a passagem da tinta para atingir a superfície visada). A técnica possibilita uma ação rápida, ideal para a pintura ilegal, e depende mais de um pré preparo do que da habilidade manual durante o ato da pintura do graffiti. Este último traço explica em parte porque a geração seguinte, do graffiti americano como introduzido no Brasil, irá inicialmente recusar esta técnica.

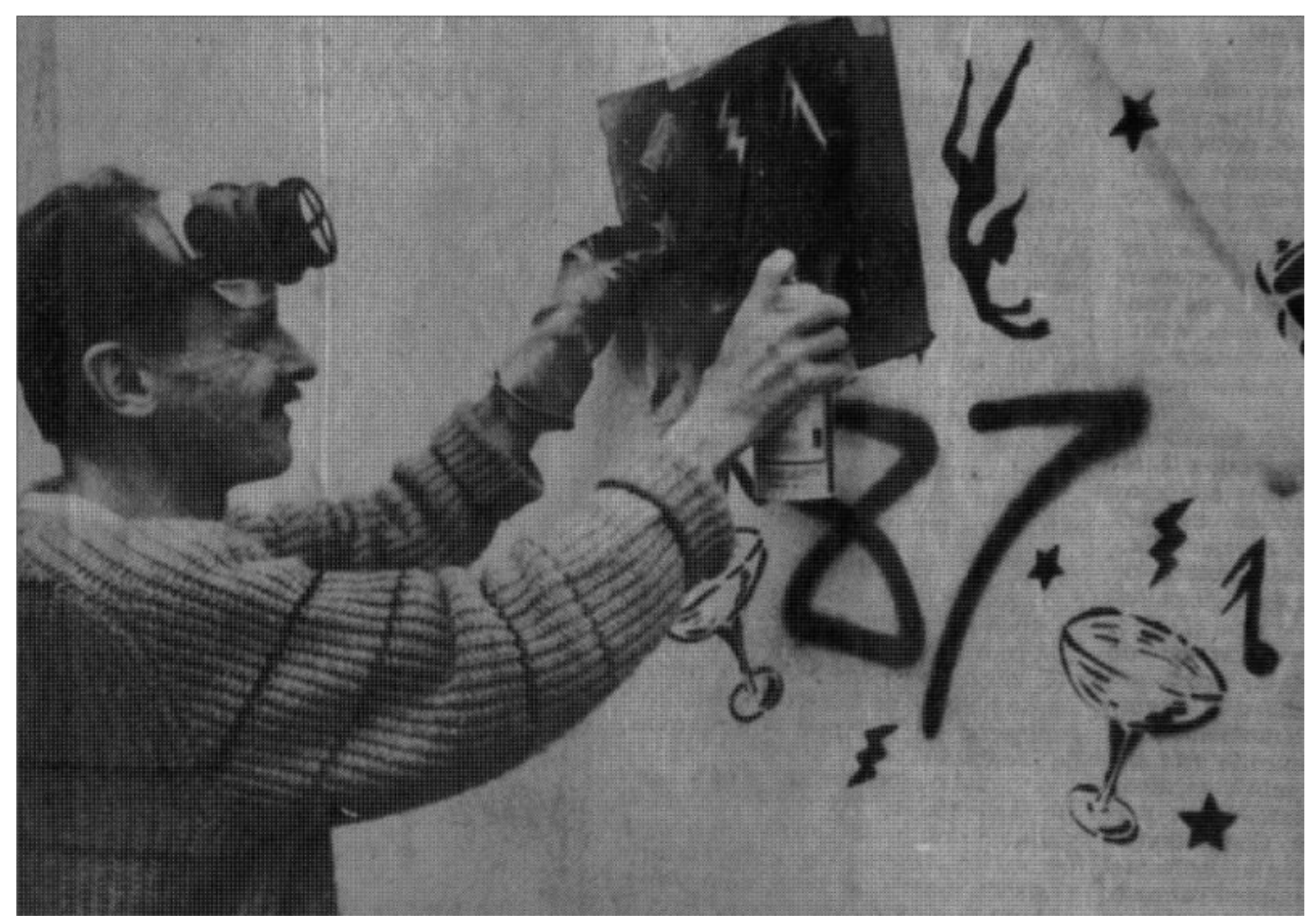

Fig. 2 Alex Vallauri usando uma máscara de estêncil, à direita a figura do acrobata, tirada de uma pintura de Georges Seurat. 


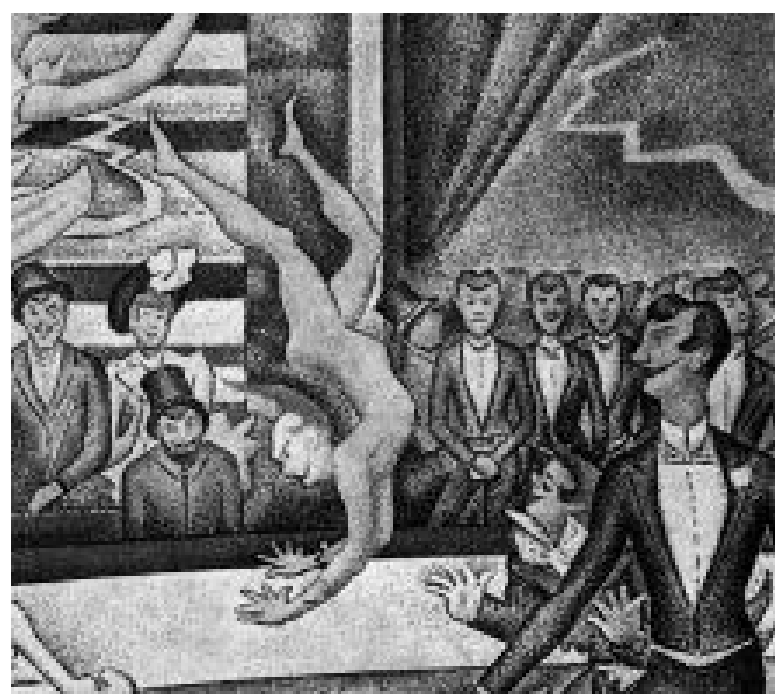

Fig.3 Detalhe da pintura "O Circo" de George Seurat mostrando a figura do acrobata usada por Alex Vallauri em seu estêncil.

O uso da figura de Seurat no trabalho de graffiti de Alex Vallauri, pode nos ajudar a levantar uma questão interessante sobre como esta pesquisa observa as diferentes práticas que trata. Há um jeito de analisar trabalhos como o de Alex Vallauri que passa por um caminho coerente e claro, que leva em conta sua educação formal -seu curso de bacharelado em artes plásticas na universidade Faap de 1968 a $1971^{22}$ - traçando uma linha direta e causal entre seu trabalho anterior de gravura até seus graffiti, como a sugestão apresentada, para citar uma ocorrência, em Estética Marginal: Volume \#2:

"Logo que chegou ao Brasil, depois de ter morado na Argentina com a família, Alex Vallauri se estabeleceu em Santos. Alí, registrou em desenho personagens que habitavam o porto, como marinheiros, prostitutas e estivadores. Lá, teve contato com o professor Hansen Bahia e estudou xilogravura com Augusto Barros, onde explorou essas imagens, que foram mais tarde adaptadas e reelaboradas em outras técnicas. Todo esse contato com o universo underground refletiu nos seus estênceis, como a botinha preta e a luvinha sexy"23

Este caminho risca a linha -Alex Vallauri gravador, Alex Vallauri grafiteiro, deixando clara a noção de um processo causal entre o Alex Vallauri de uma educação formal em técnicas reconhecidas (gravura) e o Alex Vallauri que viria a se tornar icônico em seu trabalho pop, o Alex Vallauri do graffiti.

\footnotetext{
${ }^{22}$ SPINELLI, João J. Alex Vallauri Graffiti. Pg. 36.

${ }^{23}$ Estética Marginal: Volume \#2, Pág. 35.
} 
Em conversa para esta pesquisa, Carlos Matuck deixa bem claras as principais referências para os primeiros trabalhos de Alex Vallauri, e dos seus próprios, para seus estênceis:

"Foram três coisas que aconteceram mais ou menos ao mesmo tempo na minha cabeça, esses passeios [suas andanças pelo centro da cidade de São Paulo] a descoberta dos carimbos escolares e conhecer o Vallauri. Eu já conhecia, mas eu não conhecia o trabalho dele. Eu conhecia ele porque ele era amigo do Arthur e do Rubens [dois de seus irmãos], então eu já encontrava ele por acaso em vários lugares, já nos falávamos. Quando ele começou a fazer graffiti eu já sabia que ele fazia graffiti. Quando eu fiquei amigo dele, quando começamos a conversar mais e falar de carimbos, eu descobri que ele tinha uma coleção de carimbos e conhecia um lugar fantástico chamado Carimbos Dulcemira"24.

As figuras da botinha e da luva vieram dessa pulsão colecionista alimentada pela descoberta do acervo de carimbos da fábrica Dulcemira. Contando sobre o começo do seu trabalho de graffiti, Carlos Matuck fala:

"O Vallauri já fazia a botinha, a luvinha, tudo separado. Ele carimbava né? Era umas coisas como os carimbos Dulcemira, como história em quadrinhos, a panterinha da selva, o acrobatinha que ele tirou do Seurat. Então a gente começou a fazer sessão de carimbo, ficávamos lá o dia inteiro vendo os carimbos, carimbando, compondo, vendo qual era legal com o outro".

Muitas mais das figuras que foram reconhecidas enquanto 'valaurianas' vieram dessa fonte 'dulcemiriana', como quando por exemplo os três, Zaidler, Vallauri e Matuck, fizeram a banda que consistia em três figuras humanas tocando instrumentos musicais. Um trompetista, um sanfoneiro e um guitarrista (sequência essa de acordo com o exemplo visual abaixo, já que as máscaras de estêncil podem ser facilmente espelhadas).

"ele [Zaidler] fez aquela guitarra e eu tinha acabado de trazer dos Estados Unidos um carimbinho de sanfona e aí eu fiz uma sanfonona na escala da guitarra... Aí a gente fez um trompete juntos, também do Dulcemira, ou de um carimbo americano agora eu não lembro, mas fizemos juntos lá no meu atelier, mas eu lembro a gente fazia isso, desenhava juntos. la desenhando, tal, cortava, então a gente fez um trio. $\mathrm{E}$ o Vallauri deu aquele nome maravilhoso O Trio Los Panteras, que em tudo ele botava aquelas panteras dele. E ele colocava as pinupinhas cantando juntos e virou o Trio Los Panteras y Las três Panteretas".

\footnotetext{
${ }^{24}$ Entrevista de Carlos Matuck para esta pesquisa.
} 
Esse exemplo de como funcionou a criação do trio nos mostra que grande parte do impulso da criação das figuras vinha do próprio carimbo, que depois era ampliado para a escala do estêncil e composto em cenas com figuras e pintura em spray a mão livre.

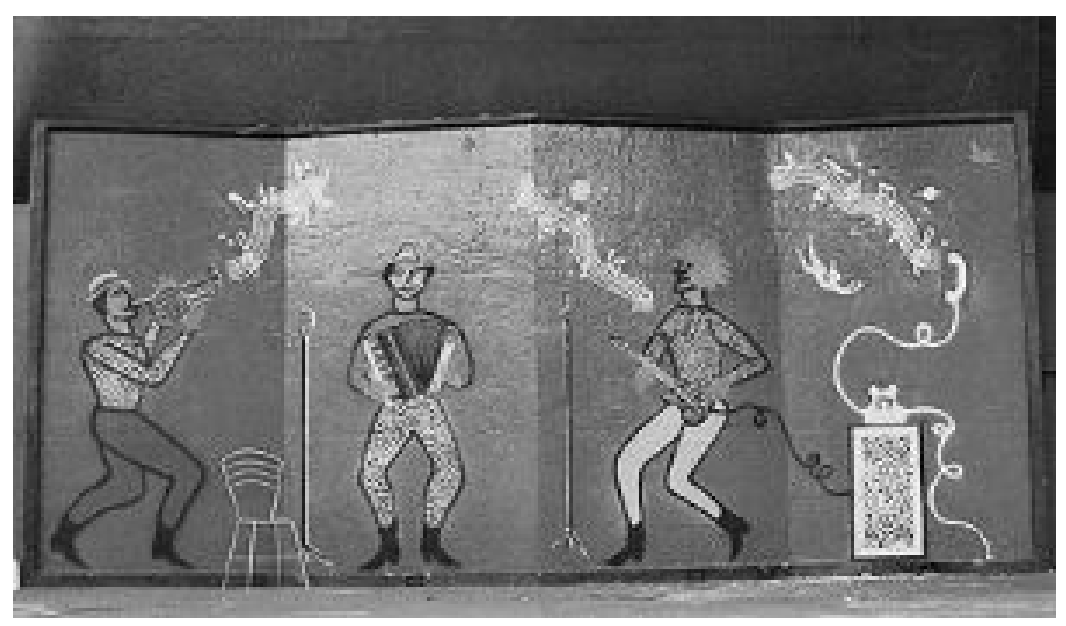

Fig. 4. O “Trio Los Panteras", pintura coletiva de Matuck, Zaidler e Vallauri.

Mas embora tenha sido um importante símbolo do graffiti, a vertente do estêncil não era a única prática de graffiti feita na época. Como bem coloca Celso Gitahy (que desde o início de seu trabalho de graffiti usa a técnica do estêncil) em seu $O$ que é Graffiti?. Gitahy chama atenção para uma divisão formal e técnica criada para separar e identificar o graffiti produzido durante a década de 1980 e além, em São Paulo:

"Como resultado da produção desses artistas neste capítulo (e outros não citados), foram criados, três estilos:

-O estilo das máscaras - escola vallauriana;

-O estilo americano - ligado ao movimento hip-hop;

-O estilo à mão livre - escola Keith Haring." 25 .

${ }^{25}$ GITAHY, Celso. O que é Graffiti? Pág. 72. 
Keith Haring foi importante para o que viria a ser posteriormente chamado de "Street art" ou no uso comum do termo em português brasileiro "Arte urbana"26. 0 autor inglês Cedar Lewisohn em seu Street Art: The graffiti revolution apresenta uma clara distinção entre o que ele designa por "Graffiti", "Graffiti Writing" e "Street art":

"Por 'graffiti' é geralmente entendido que significamos qualquer forma de aplicação não oficial e não autorizada de um meio em uma superfície... 'Graffiti Writing', que é separado do graffiti, é o movimento proximamente associado à cultura hip hop (embora seja anterior à ela), cuja principal preocupação é o 'tag' ou assinatura do autor... 'Street art' é um subgênero do graffiti writing e deve muito ao seu predecessor. Apesar de haver muita troca entre os gêneros, eles são distintos e separados por suas próprias qualidades". ${ }^{27}$

Através dessas definições, a identificação da produção brasileira com o primeiro termo apresentado por Cedar -"Graffiti" poderia ser análoga ao que chamamos genericamente de "Pichação", o segundo termo "Graffiti writing" claramente identificando o "Graffiti americano"; o terceiro termo só teria um análogo em português brasileiro a partir da década de 2000, quando os termos "Street art" e "Arte urbana" começam a identificar o mesmo tipo de produção descrita pelo autor. Cedar Lewisohn encaixa o trabalho de Keith Haring e Jean-Michel Basquiat, outro artista que além de seu trabalho de atelier, também teve reconhecida a produção da pintura mural durante a década de 1970 e 1980 em Nova lorque:

\footnotetext{
${ }^{26}$ Este termo começou a ser usado mais amplamente a partir da década de 2000 no Brasil. Embora o termo será analisado mais pormenorizadamente no decorrer da pesquisa, ao menos a separação conceitual entre os termos "Arte urbana" e "Graffiti" já começa a ser interessante neste momento da década de 1980 no que concerne a produção da primeira onda de "Graffiti" paulistano.

${ }^{27}$ No original em Inglês "By 'graffiti', it is generally understood that we mean any form of unofficial, unsanctioned application of a medium onto a surface... 'Graffiti writing;', which is separate from graffiti, is the movement most closely associated with hip hop culture (though it predates it), whose central concern is the 'tag' or signature of the author... 'Street art' is a sub-genre of graffiti writing and owes much to its predecessor. Though there is a good deal of crossover between the genres, they are distinct and separate in their own right." LEWISOHN, Cedar. Street Art: The Graffiti Revolution. Pág. 15.
} 
"Em 1981, The Washington Project For The Arts montou uma exposição chamada Street Art, que incluía John Fekner, Fab 5, Freddy, and Lee ${ }^{28}$. Apesar de outras exposições como New York New Wave terem levado estes artistas a museus, é justo dizer que durante os anos 1980 artistas trabalhando puramente no ambiente urbano eram geralmente ignorados pelo estabelecimento do mundo das artes. Apenas artistas dessa cena que começaram a trabalhar dentro do sistema de galerias eram reconhecidos.

Por esse motivo, muitos artistas muito talentosos permaneceram pouco conhecidos. Figuras mais celebradas como Keith Haring, Kenny Scharf e Jean-Michel Basquiat surgiram ligeiramente depois de tipos como Fekner e Holzen, mas todos estavam presentes na lendária exposição Times Square Show. Haring e Basquiat podem claramente ser definidos como pioneiros do street-art, em oposição aos pioneiros do graffiti-writing". ${ }^{29}$

E qual seria a importância dessas figuras tidas como pioneiros do que viria a ser chamado de "Street art" ou "Arte urbana" na produção de pintura mural dos anos 1980 em São Paulo? Celso Gitahy identifica a produção do que chama de "Estilo à mão livre" diretamente com Keith Haring, que veio a São Paulo junto com Kenny Scharf ${ }^{30}$ para a $17^{\mathrm{a}}$ Bienal de São Paulo em 1983. ${ }^{31}$

Em entrevista para o livro Estética Marginal \#2, Rui Amaral, artista e grafiteiro que tem ampla produção mural desde a década de $1980^{32}$, e que participou como monitor desta edição da bienal de São Paulo e saiu para pintar na rua com Keith Haring, ressalta o afastamento de sua obra da de Keith Harring:

"Quando eu estava com 20 anos olhando a cidade como artista, eu percebi uma nova produção de arte e percebi que era uma mídia nova que tava rolando no

\footnotetext{
${ }^{28}$ Reconhecidos artistas dentro do circuito do "Graffiti americano".

${ }^{29}$ LEWISOHN, Cedar. Street Art: The Graffiti Revolution. Pág. 93. Original em inglês: "In 1981, The Washington Project For The Arts held an exhibition entitled Street Art, which included John Fekner, Fab 5, Freddy, and Lee. Although other exhibitions such as New York New Wave brought these artists into museums, it is fair to say that during the 1980s, artists working purely in the urban setting were generally ignored by the art-world establishment. Only the artists from this scene who started to work within the gallery system were acknowledged.

For this reason, many very talented artists from this period remain little known. More celebrated figures such as Keith Haring, Kenny Scharf and Jean-Michel Basquiat emerged slight later than the likes of Fekner and Holzen, but all featured in the legendary 1980 Times Square Show. Haring and Basquiat can clearly be defined as street-art pioneers, as opposed to graffiti-writing pioneers".

${ }^{30}$ Kenny Scharf, também citado por Cedar Lewisohn na passagem acima, era representado pela mesma galeria que Keith Haring e possuía um trabalho de pintura mural e em objetos que assim como Keith Haring não se encaixava tão bem dentro dos moldes do "Graffiti nova-iorquino".

31 Catálogo Geral da 17 Bienal de São Paulo, 1983.

32 Seu trabalho pode ser conhecido facilmente pelo mural permanente que mantém no túnel que liga a Avenida Paulista à Avenida Dr. Arnaldo, apresentando figuras coloridas sobre um fundo azul.
} 
mundo. E eu já tinha inserção, brincava com a latinha, gostava de desenhar. Foi meio natural fazer desenho como espaço de manifestação de arte com as pessoas vendo. Na época da monitoria (durante a Bienal de 1983), eu já fazia isso". ${ }^{33}$

Alguns pontos visuais da pintura mural a mão livre podem ser identificados com traços da pintura de Keith Haring, diferentes da pintura mural do "Graffiti internacional" que chegou posteriormente em São Paulo, por volta de 1985. Assim como no trabalho de Keith Haring, de maneira geral o trabalho de artistas como Rui Amaral, Jaime Prades, Ciro Cozzolino, Carlos Delfino, além de grupos como o Tupinãodá e o 3 NÓS 3, apresenta uma pintura mural feita não apenas com spray (importante característica do "Graffiti nova-iorquino"), mas com grossas linhas pintadas com pincel ou rolinho de espuma, mesclando uma pintura linear que traça figuras pop a pinturas abstracionistas em poucas cores. A diferença visual vinda das diferentes técnicas, o uso de estêncil ou mão livre, define o tipo de trabalho que foi desenvolvido por cada artista na época.

É difícil identificar um tema geral ou técnica estanque que defina o trabalho dos grafiteiros do final dos anos 1970 e começo dos anos 1980, dados os múltiplos referenciais de cada artista. Esta variedade pode ser bem observada no livro Estética Marginal Volume \#2, que apresenta imagens de diversos artistas da época que podem ser identificadas grosso modo com as duas "escolas" definidas por Celso Gitahy. Essa profusão de estilos e referências também auxilia a aprofundar a linha que divide esse grupo do seguinte, o do graffiti produzido em São Paulo nos moldes americanos. Podendo ou não ser identificada diretamente com o trabalho de Keith Haring ou Alex Vallauri, a produção do grupo de pintores murais do começo dos anos 1980 em São Paulo se destaca do trabalho posterior de graffiti, pintura clara e imediatamente identificada com a produção da pintura mural nova-iorquina, na tradição do que Cedar Lewisohn designa por "Graffiti writing".

${ }^{33}$ Estética Marginal \#2. Pág. 69. 


\subsection{O Graffiti de Matriz Nova-iorquina}

Mundialmente, o termo graffiti é sinônimo da pintura mural nascida em Filadélfia na década de $1960^{34}$ e desenvolvida na década de 1970 em Nova lorque, onde adquiriu todos os elementos básicos pelos quais seria reconhecida e reproduzida internacionalmente. A pesquisa do artista e fotógrafo Jack Stewart nos apresenta com minúcia o início do desenvolvimento do estilo de pintura nos metrôs de Nova lorque na década de 1970. Sua tese de PhD, foi publicada em seu formato final como o livro Graffiti Kings: New York City Mass Transit Art of The 1970s em 2009, quatro anos após o falecimento do autor por sua esposa Regina Stewart. No que concerne esta pesquisa, não cabe repetir o que foi dito de maneira bem mais pormenorizada e precisa, por quem desde o ano de 1970 e durante toda essa década fotografou, acompanhou e conheceu os praticantes do início do graffiti que viria a ser adotado através do mundo nas décadas seguintes. Vale, no entanto, apontar quando e através de que meios esse conjunto de exemplos visuais, procedimentos e valores, chegou até o Brasil e afetou a produção local de pintura e escrita mural.

Em meados da década de 1980 os muros da cidade de São Paulo, como se viu, não eram tela em branco. A prática do estilo nova-iorquino desde o princípio precisou se propor autônoma em relação aos outros estilos de pintura e escrita mural que já existiam aqui. Tristan Manco, autor inglês estudioso das diversas ramificações da prática do graffiti no mundo, indica com clareza em seu Graffiti Brasil: "Até meados dos anos 1980, a cena brasileira de graffiti era basicamente nascida em casa e dividida em grafite (murais de graffiti) e pichação. Embora algumas influências artísticas tenham vindo de fora, a cultura em si foi de sua própria criação" 35 . Reforçando a separação entre a produção anterior e a introdução do graffiti nova-iorquino no Brasil, o autor continua;

\footnotetext{
${ }^{34}$ Tanto a origem em Filadélfia do graffiti feito por indivíduos que não era associado a gangues, chamados "loners", quanto sua migração para Nova lorque é extremamente detalhada com exemplos fotográficos nos dois primeiros capítulos do livro Graffiti Kings, de Jack Stewart.

35 "Until the mid-1980s the Brazilian graffiti scene was very much home-grown and divided into grafite (graffiti murals) and pichação. While some artistic influences had come from abroad, the culture itself was of its own making." No original em inglês, Pag. 15 Graffiti Brasil.
} 
"À essa mistura, veio acrescentar-se o hip-hop e o estilo de Nova lorque de graffiti. Da mesma forma que a cultura hip-hop se espalhou ao redor do mundo, foram filmes como Beat Street que capturaram a imaginação de muitos futuros breakdancers e artistas de graffiti" ${ }^{36}$.

Esta noção mostrada por Tristan Manco do graffiti de estilo nova-iorquino no Brasil em meados dos anos 1980 com os outros elementos do hip-hop, especialmente via cinema, foi corroborada por uma conversa entre algumas figuras importantes para o começo do graffiti desse estilo no Brasil; Speto, Binho, Tinho e Vitché, acontecendo dia 23 de Outubro de 2015 na Livraria Cultura do Conjunto Nacional, em São Paulo. Na conversa sobre o começo de sua prática nas ruas de São Paulo, Speto expõe quando eles começaram e de onde vieram suas referências:

"...eu acho que eu, você [se referindo a Binho] e o Vitché, devemos ter começado mais ou menos em 1985. Foi quando passou o filme ${ }^{37}$, que eu vi em Santana. 1985 foi bem o final da ditadura militar, tinha aquele sentimento de liberdade. Naquela época, como o Tinho falou do filme, tinha o Ramon que era o personagem [principal] do filme, Beat Street. Como não tinha nem videocassete, aquele filme [visto no cinema] era toda a informação que a gente tinha e nada mais. Nada de técnica de desenho, a gente tinha que lembrar, era quase impossível achar uma foto que tivesse um graffiti, um bomb, qualquer coisa" ${ }^{38}$

\footnotetext{
36 "Into this mix, came hip-hop and the New York style of graffiti. In much the same way that hip-hop culture spread around the world, it was films such as Beat Street that captured the imagination of many soon to be breakdancers and graffiti artists". No original em inglês, Pag. 15 Graffiti Brasil. ${ }^{37}$ Beat Street, filme de 1984, conhecido no Brasil como "A Loucura do Ritmo", responsável por introduzir a cultura do hip-hop do começo dos anos 1980 no Brasil e outras partes do mundo.

${ }^{38}$ Conversa na Livraria Cultura, 23 de Outubro de 2015.
} 


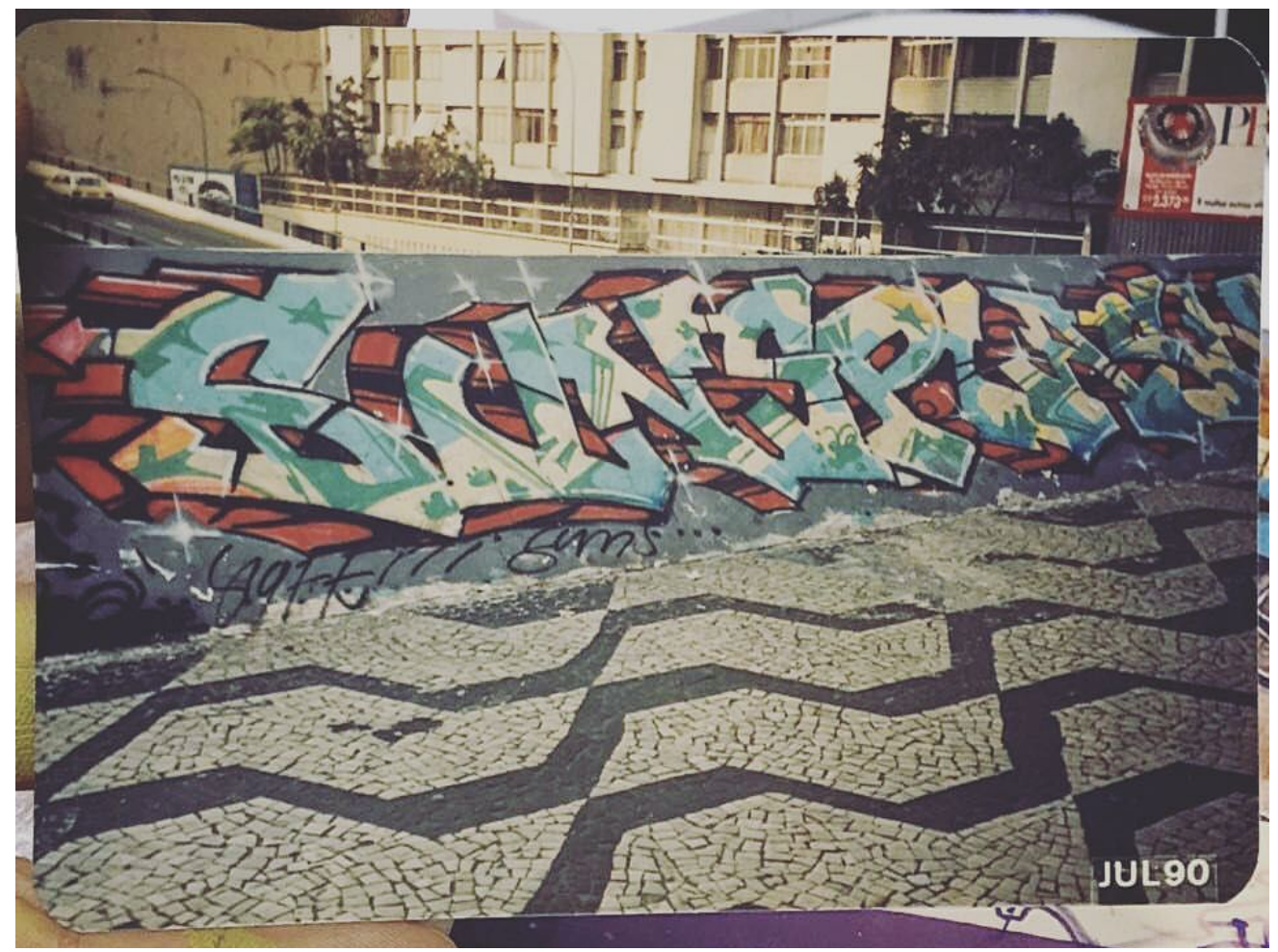

Fig 4. Graffiti feito por Speto em 1990, com todos os elementos do graffiti americano no estilo internacionalmente conhecido como Wild Style.

Outra importante fonte de referência para esse grupo inicial de praticantes do graffiti ao estilo americano em São Paulo, foram dois livros -Subway Art, de Martha Cooper e Henry Chalfant e Spraycan Art de Henry Chalfant e James Prigoff. Os dois livros, publicados respectivamente pela primeira vez nos Estados Unidos em 1984 e 1987, foram de extrema importância para mostrar a cultura hip hop e o "Graffiti americano" para o resto do mundo. Binho descreve o primeiro contato que eles tiveram com os livros:

"Nessa livraria aqui, eu acho que foi nessa ou alguma ao redor. Foi logo que a gente se conheceu e começou a falar sobre graffiti, desenho, a gente não tinha grana pra comprar o livro Subway Art e o Spraycan Art então eu comprei um e ele [se referindo a Speto] comprou o outro e a gente dividia".

Ao que Speto o confirma e precisa melhor a época em que conseguiram ter acesso aos livros:

"Os livros que o Binho falou, que a gente veio aqui correndo comprar, vieram sete anos depois que a gente começou a pintar. Muito tempo se passou só na roubada, sem norte nenhum, mas com muita diversão. Eram os graffiti mais horríveis do planeta". 
Mas se os graffiti que se baseavam no estilo nova-iorquino eram realmente distintos da produção mural paulistana anterior, no que eles consistiam exatamente? 


\subsubsection{Os elementos de um graffiti nova iorquino}

O trabalho de Jack Stewart foca especialmente nos graffiti feitos nos trens do metrô da cidade de Nova lorque no decorrer da década de 1970, inicialmente escritos com canetas marcadoras e spray no interior dos carros. Eram escrituras feitas em uma cor, que normalmente apresentavam o apelido do escritor junto com um número que fazia referência ao seu endereço, como o famoso (TAKI 183, um dos primeiros escritores de graffiti a atacar o metrô de Nova lorque, TAKI sendo o diminutivo de seu nome Dimitraki e 183 o número da rua onde morava). Foi no ano de $1971^{39}$ que os graffiti começaram a sair do interior dos carros do metrô, pois lá fora havia mais espaço para serem trabalhados em maior escala, desenvolvendo assim os elementos pelos quais seriam conhecidos nas décadas seguintes.

Com essa mudança de suporte, a assinatura de nomes em uma cor se desenvolveu em grandes e multicoloridos letreiros acompanhados de figuras, além de letreiros arredondados chamados de bubble letters, graffiti feitos com mais rapidez chamados, throw ups, no Brasil muitas vezes chamados de bombs), avançam até as pinturas mais trabalhadas com várias cores chamadas de master pieces (ou mais correntemente conhecidas pela abreviatura piece). Os termos próprios dos praticantes do graffiti nova-iorquino foram adotados posteriormente em outras regiões dos Estados Unidos e do mundo ampliando a disseminação de uma unidade de termos que estabeleceu uma comunidade global de praticantes para além das barreiras de língua.

Observando os graffiti da década de 1970 fotografados por Jack Stewart, fica claro qual dos elementos veio antes -a letra anterior à figura. No Brasil, ao menos quando se trata dessa linhagem de graffiti, não foi diferente: em conversa para essa pesquisa, o grafiteiro e artista Onesto, iniciado na prática da pintura mural dentro da prática do graffiti nova-iorquino, diz com todas as letras: "Quando eu comecei a fazer graffiti, eu coloquei na minha cabeça que eu tinha que primeiro a aprender a fazer algumas letras decentes para depois ir para o personagem. Por mais que eu já

${ }^{39}$ Graffiti Kings, pág 41. 
desenhasse personagens desde pequeno, acho que letra é o fundamental. Isso que é fazer graffiti." 40

Esse traço, do foco inicial na letra, e não na figura, ajuda a distanciar os graffiti feitos em São Paulo antes da chegada do graffiti nova-iorquino em meados dos anos 1980 em relação ao que era praticado aqui antes, tanto na vertente do estêncil (Vallauri, Matuck, Zaildler) quanto no graffiti a mão livre. Por mais que fossem distintas entre si, nenhuma das práticas desenvolvidas no Brasil anteriormente valorizava a pintura de letreiros, mas de figuras. A "Pichação poética" era baseada na escrita, mas parecia ser mais focada na ideia trazida pela palavra, embora ocasionalmente assessorada de elementos visuais do que no adorno do letreiro em si. A ênfase na pintura figurativa, e posteriormente a abstrata, adotada por muitos grafiteiros criados na tradição do graffiti nova-iorquino começou a mostrar mais força na década de $1990 .{ }^{41}$ Antes desse impulso figurativo, o principal objeto da pintura de graffiti nessa tradição era o letreiro.

\footnotetext{
${ }^{40}$ Entrevista Onesto em anexo.

${ }^{41}$ Os processos de tomada da figura como objeto principal dos grafiteiros que se formaram na tradição nova iorquina e a individuação de seus trabalhos, na direção de uma pintura que se destaca com mais clareza do trabalho de outros praticantes, será melhor trabalhada em outro capítulo dessa pesquisa.
} 


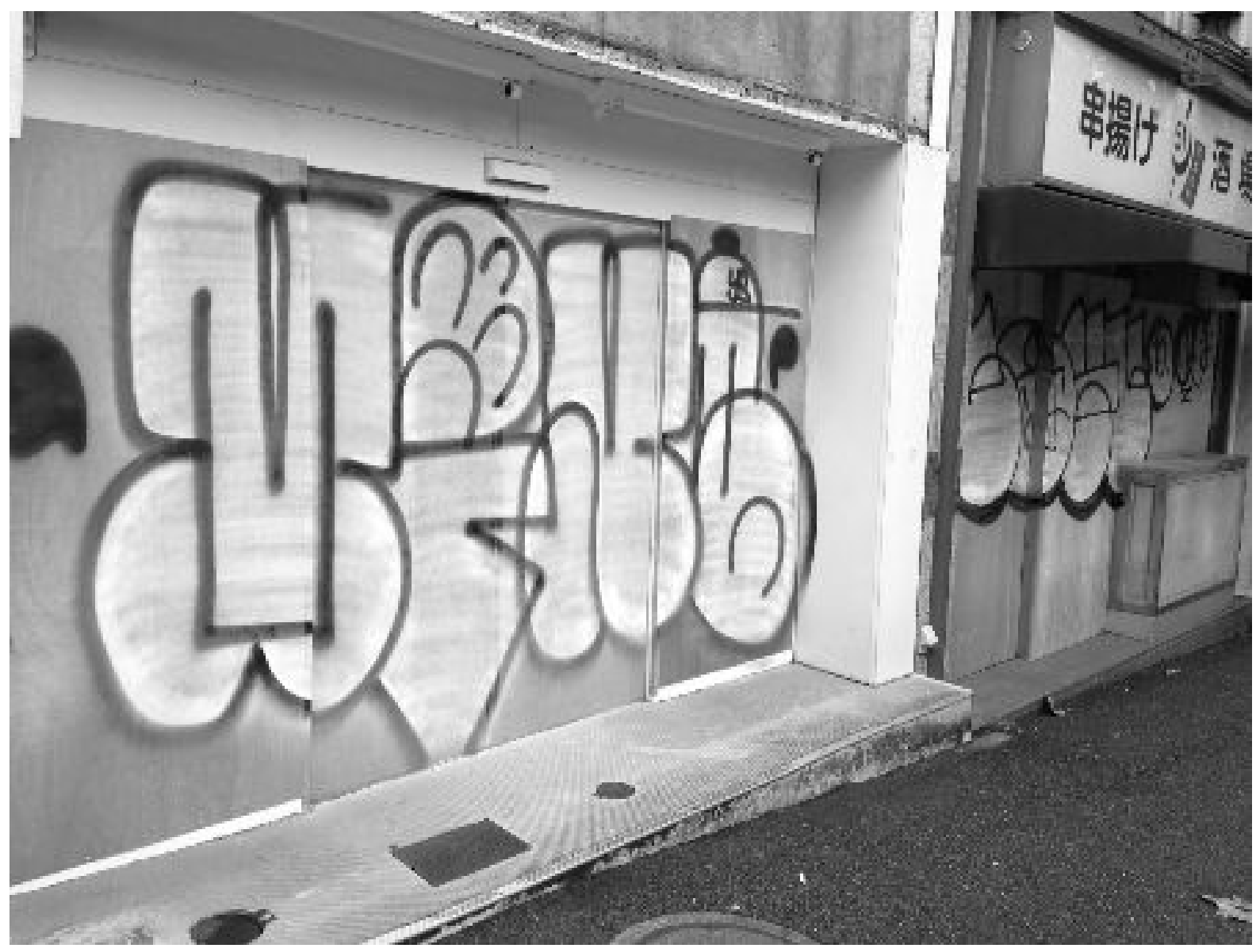

Fig 6. Graffiti fotografado em setembro de 2016 em Tóquio, no distrito de Shibuya.

O graffiti acima poderia ter sido pintado em praticamente qualquer país no mundo, do Chile à Austrália, da África do Sul ao Reino Unido. Qualquer cidade que tenha adotado a prática do "Graffiti americano" seria capaz de produzir esse throw up no estilo bubble letter a partir de meados dos anos 1980. Foi com essa suposição que ao visitar a cidade de Tóquio no Japão eu comecei a observar a produção de graffiti local, tentando verificar se a ideia de que até por lá o graffiti nova-iorquino era praticado nos mesmos moldes que os observados no Brasil. Embora não seja corriqueiro ver um graffiti, ou tag, ou pichação, ou lambe-lambe como em São Paulo, onde raramente você dá a volta em um quarteirão sem enxergar algum tipo de ataque aos muros, em todos bairros que visitei em Tóquio 
com algum tipo de pintura mural não autorizada, ela estava plenamente de acordo com a prática do "Graffiti internacional".

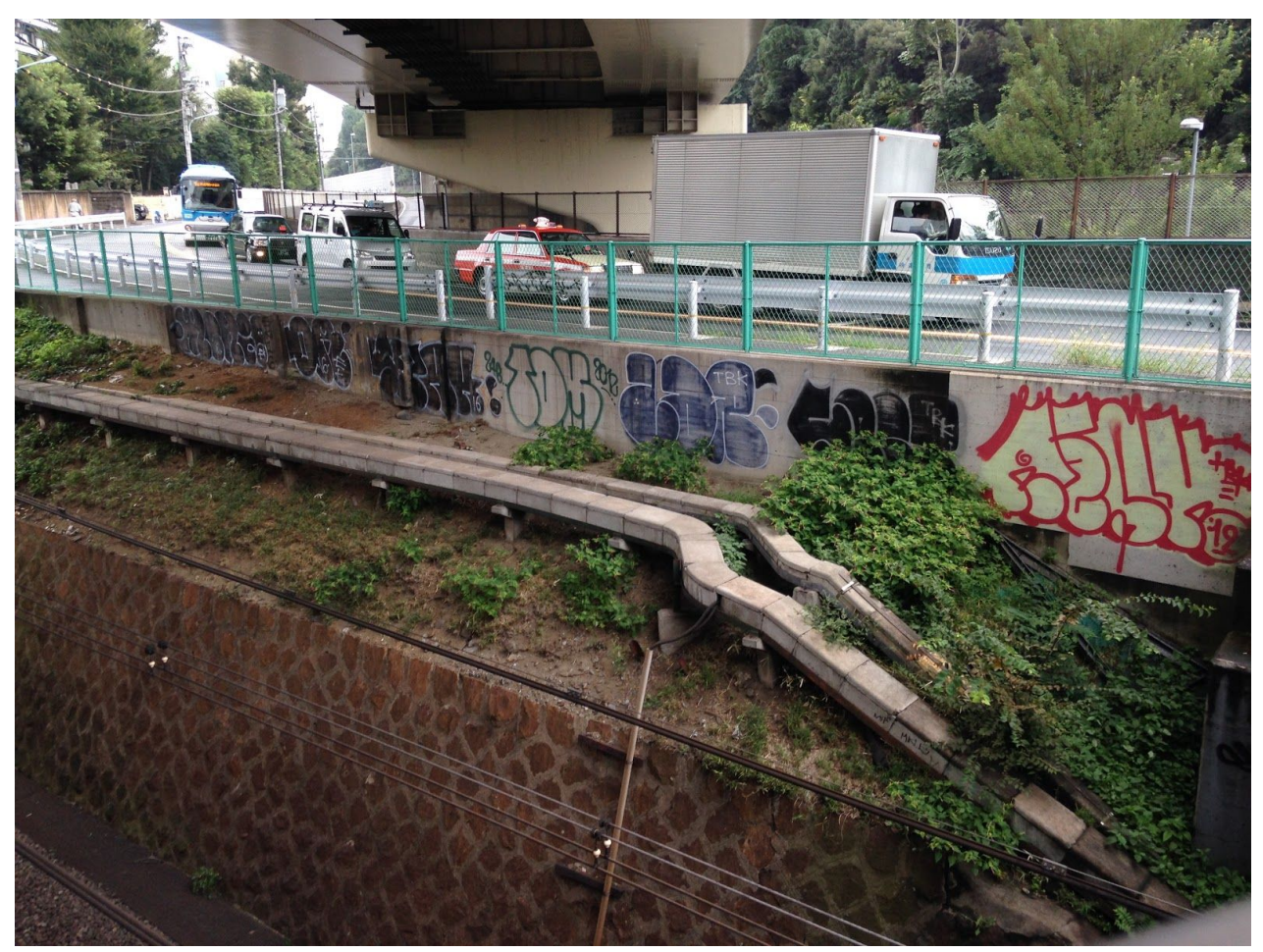

Fig 7. Graffiti no bairro de Shinjuku, Tóquio, ao lado da linha de trem. 


\title{
1.2.3 A Novidade brasileira
}

Os grafiteiros que se formaram na escola do "Graffiti nova-iorquino" são muito mais numerosos do que os das práticas anteriores do graffiti do final de 1970 e começo de 1980. É pela novidade da sua pintura mural desviada a partir do "Graffiti nova-iorquino" que o Brasil passou a ser reconhecido mundialmente como referência para a pintura e escritura mural, como se lê em Tristan Manco:

\begin{abstract}
"O Brasil se gaba de uma cena de graffiti única e particularmente rica, que em anos recentes tem ganhado a reputação internacional de o lugar a ir em busca de inspiração artística. No passado, os artistas de graffiti brasileiros foram influenciados pelas cenas americana -e em menor grau- europeia, mas era difícil obter informação sobre o que estava acontecendo fora do país. Esse isolamento gerou novos estilos e técnicas, e restrições econômicas forçaram os artistas a adaptar e improvisar". ${ }^{42}$
\end{abstract}

Esta reputação internacional do graffiti brasileiro se deu através de nomes como Speto, Os Gêmeos, Herbert, Vitché, Tinho, Onesto, Ciro, Zezão, e muitos e muitos outros artistas que tiveram a sua principal formação e técnica no "Graffiti americano". Cada um deles a partir dessa prática começou a desenvolver uma linha autoral de pintura mural, a que se acrescentou trabalhos paralelos como pintura em suportes tradicionais telas, painéis, escultura, instalação, fotografia, e muitas das técnicas que da produção artística contemporânea. Como esse processo se deu? O início do processo de individuação desses artistas pode ter surgido pelos motivos apontados por Tristan Manco -isolamento do resto do mundo e limitação materialmas essa suposição não responde às questões propostas pela novidade brasileira.

Em outro capítulo, serão levantadas algumas hipóteses sobre os motivos dos processos de desenvolvimento do graffiti brasileiro, com exemplos mais precisos de

\footnotetext{
${ }^{42}$ MANCO, Tristan. Graffiti Brasil, Pág. 7. "Brazil boasts a unique and particularly rich graffiti scene, which in recent years has earned it an international reputation as the place to go for artistic inspiration. In the past Brazilian graffiti artists were influenced by the American -and to a lesser extent- European scenes, but it was difficult to obtain information about what was happening outside the country. This isolation generated new styles and techniques, and economic restrictions forced artists to adapt and improvise".
} 
artistas que traçaram esse caminho do "Graffiti americano" ao trabalho autoral. A este processo chamo de individuação, posto que aos olhos de um público amplo, o graffiti feito nos moldes norte-americanos tem a autoria embaçada pela unicidade estilística dos letreiros e personagens, onde a figura autoral do grafiteiro muitas vezes se perde dentro dos moldes restritivos do "Graffiti internacional".

Apesar de muitos dos grafiteiros que se formaram nos moldes do "Graffiti americano" terem passado por um processo de individuação, e de muitos dos grafiteiros e artistas de gerações posteriores já terem começado a pintar nas ruas pensando em um estilo pessoal, o "Graffiti americano" ainda subsiste de maneira pura em São Paulo nos dias de hoje. A partir dos anos 2000 não apenas o Brasil mas o mundo todo passou por uma transformação na produção de pintura e escritura mural, com a popularização de outras técnicas e estilos além da adoção da ideia de "Street art", produção dirigida para um público amplo. Pois o "Graffiti americano", pela estrita definição de seu estilo e regras internas, pôde continuar existindo de maneira quase inalterada. Entretanto nem só de graffiti os muros de São Paulo foram cobertos em meados e final da década de 1980 em São Paulo. Uma cena paralela que existe muito forte até hoje e também pode ser apontada como responsável pela projeção mundial da pintura e escritura mural paulistana, o "Pixo". 


\subsection{Pixo}

\subsubsection{Pichação paulistana}

"Depois de pichar quase todos os espaços disponíveis ao nível do solo, os pichadores de São Paulo estão buscando novos desafios. Na avenida Brigadeiro Faria Lima, em Pinheiros (zona oeste de São Paulo), vários prédios têm pichações nos últimos andares. No edifício Barão de Rothschild, na av. Faria Lima, 1885, esquina com a av. Rebouças, há pichações na laje, na parede lateral e no $16^{\circ}$ andar, a 60 metros de altura. Para chegar até o telhado, os pichadores tiveram que passar pela casa de máquinas do edifício e pular uma pequena janela que dá para o alto do prédio". ${ }^{43}$

Esta passagem da reportagem não assinada na Folha de São Paulo em 9 de fevereiro de 1990, com a chamada "Laje e topo de prédios são os novos alvos da pichação" mostra como agiam no início dos anos 1990 os pichadores paulistanos. A mundialmente reconhecida "Pichação paulistana" havia acabado de surgir no final da década de $1980^{44}$, mas já apresentava todos os traços que a destaca de outras práticas semelhantes no resto do Brasil e no mundo. François Chastanet, arquiteto e designer francês que se dedica à pesquisa do que ele chama de epigrafia contemporânea, apresenta em seu primeiro livro "Pixação: São Paulo Signature" a novidade da "Pichação paulistana":

"A cena das pixações ${ }^{45}$ é única, já que diferente da maioria dos outros panos de fundo americanos, europeus e até mesmo asiáticos, que eram reproduções, com maior ou menor distorção do estilo de letreiro desenvolvido em Nova lorque, ela desenvolve imagens caligráficas completamente diferentes". ${ }^{46}$

A escrita em topos de prédio descrita pela matéria na Folha de São Paulo também mostra a inovação paulistana ao escrever em suportes supostamente inalcançáveis. Se a pichação paulistana se separa das tradições do "Graffiti

\footnotetext{
${ }^{43}$ Reportagem de 9 de fevereiro de 1990 publicada na Folha de São Paulo.

${ }^{44}$ Como ficará claro especialmente com as datas apresentadas na coleção de "Entrevistas do Caixão" os mais antigos grupos que praticam a típica "Pichação paulistana" começam a surgir entre 1986 e 1989.

${ }^{45}$ As distintas grafias "Pichação" e "Pixação" serão discutidas no decorrer desse capítulo.

${ }^{46}$ CHASTANET, François. Pichação São Paulo Signature, Pág. 237."The pixações scene is unique, since, unlike most other American, European, and even Asiatic backgrounds, where are reproduced, with more or less distortion, the lettering style developed in New York, it develops a totally different calligraphic imagery." no original.
} 
internacional" como Chastanet diz, não é por seu caráter "vândalo", já que muita da energia que impulsionou o desenvolvimento do "Graffiti nova-iorquino" em seus primórdios também partia da adrenalina do risco, do proibido. Mas a "Pichação paulistana" tomou essa energia como um dos seus nortes, como se verá adiante.

Os começos da "Pichação paulistana" são incertos, como aponta Gustavo Lassala em seu livro "Pichação não é Pixação":

"Em meados dos anos 1980 surge em São Paulo a pixação que, aos poucos, foi ocupando os muros e prédios da cidade, com escritos de grupos e nomes, normalmente feitos em tinta spray ou rolo de espuma usado com tinta látex e letras grandes, angulares e bem características que, acredita-se, inspiradas nos logotipos de bandas punk e heavy metal como Ratos de Porão, Kiss, Iron Maiden etc". ${ }^{47}$

Essa indicação matricial das "Pichação paulistana" (também feita por Chastanet) ${ }^{48}$ mais propõe a origem do estilo da letra do que um conjunto de exemplos visuais e regras de procedimento vindos de fora, como visto nos graffiti de matriz nova-iorquina, que mostram não apenas o que fazer, mas como fazê-lo. Chastanet aponta a necessidade da diferença visual da letra da "Pichação paulistana" em relação com outras práticas:

"Certas qualidades plásticas das blackletters parecem ter sido assimiladas subsequentemente com o objetivo de permitir que certos grupos de pixadores se diferenciem, de um ponto de vista estético, das inscrições políticas contra a ditadura e mensagens poéticas que se encontravam nas ruas do começo dos anos 1980". ${ }^{49}$

Referindo-se nessa passagem tanto à pichação de caráter político da década de 1960 quanto à "Pichação poética" de 1970. No final do mesmo parágrafo Chastanet reitera a singularidade da "Pichação paulistana": "Estamos assim lidando

\footnotetext{
${ }^{47}$ LASSALA, Gustavo. Pichação não é Pixação.

${ }^{48}$ CHASTANET. Pág. 237.

${ }^{49}$ CHASTANET. Págs. 237 -238. "Certain plastic qualities of the blackletters seem subsequently to have been assimilated in order to allow certain groups of pixadores to differentiate themselves, from an aesthetic viewpoint, from the political inscriptions against dictatorship and poetic messages to be found in the streets in the early 1980s" no original.
} 
com um fenômeno paralelo, independente, com sua própria história, desconectado da história de Nova lorque e sua influência mundial" ${ }^{50}$

Mesmo não tendo uma matriz tão facilmente identificável quanto o "Graffiti internacional", a "Pichação paulistana" tem uma história própria, contada paralelamente à de outras práticas. A sua particularidade visual frente a outras escrituras e pinturas murais se torna de fácil identificação quando suas características básicas são apontadas, como se verá com os exemplos descritivos e fotográficos: algumas distinções conceituais também indicam a singularidade da "Pichação paulistana" não apenas em seu caráter visual, mas também de feitio, e especialmente quanto aos valores que levam os pichadores paulistanos a arriscar as próprias vidas em sua ousadia nos muros, prédios, viadutos e mais superfícies da cidade que estiverem ao seu alcance.

${ }^{50}$ CHASTANET. Pág. 238. "We are thus dealing with an independent, parallel phenomenon, with its own history, disconnected from the history of New York and its worldwide influence." no original. 


\subsubsection{Pichação x Pixo}

Costumeiramente os praticantes da "Pichação paulistana" se referem à própria ação de pichar como "fazer um pixo". O que Lassala apresenta em seu trabalho, como bem indicado no título de seu livro, é a separação entre a comumente chamada pichação e a presente "Pichação paulistana", no uso dos termos "pichação" e "pixação", respectivamente. Essa distinção na grafia é útil, já que o termo geral "Pichação" pode ser confundido com a definição mais estrita indicada aqui pelo termo "Pichação paulistana": não se confunda a "Pichação" praticada em São Paulo com a "Pichação paulistana"; já a designação "Pixo", que chama atenção por seu desvio ortográfico, é capaz de valorizar a distinção das práticas pelo espanto suscitado no leitor atento à grafia correta.

Vale notar que na língua inglesa, onde se originaram as principais nomenclaturas das técnicas do "Graffiti internacional", não existe uma diferença clara entre os termos "Graffiti” e "Pichação" como utilizados no Brasil. Geralmente, quando se fala "Graffiti" no Brasil, costuma-se pensar em uma pintura mural figurativa feita com várias cores, em contraposição a uma "Pichação" que tenderia à escrita feita em uma cor. Nos Estados Unidos e na Inglaterra o termo "Graffiti" designa claramente qualquer inscrição ou pintura mural, desde uma assinatura rabiscada em um telefone público ao mais complexo piece pintado em um grande muro, acompanhado de uma trabalhada e multicolorida pintura figurativa. $O$ nome "Pichação", por sua vez, delimita as práticas murais que dão mais importância à escritura do que à figura, mas ao nos referirmos especificamente ao tipo de pichação nascida em São Paulo, é mais prático usar o nome dado pelos próprios pichadores -a grafia com "X" em vez de "Ch". 

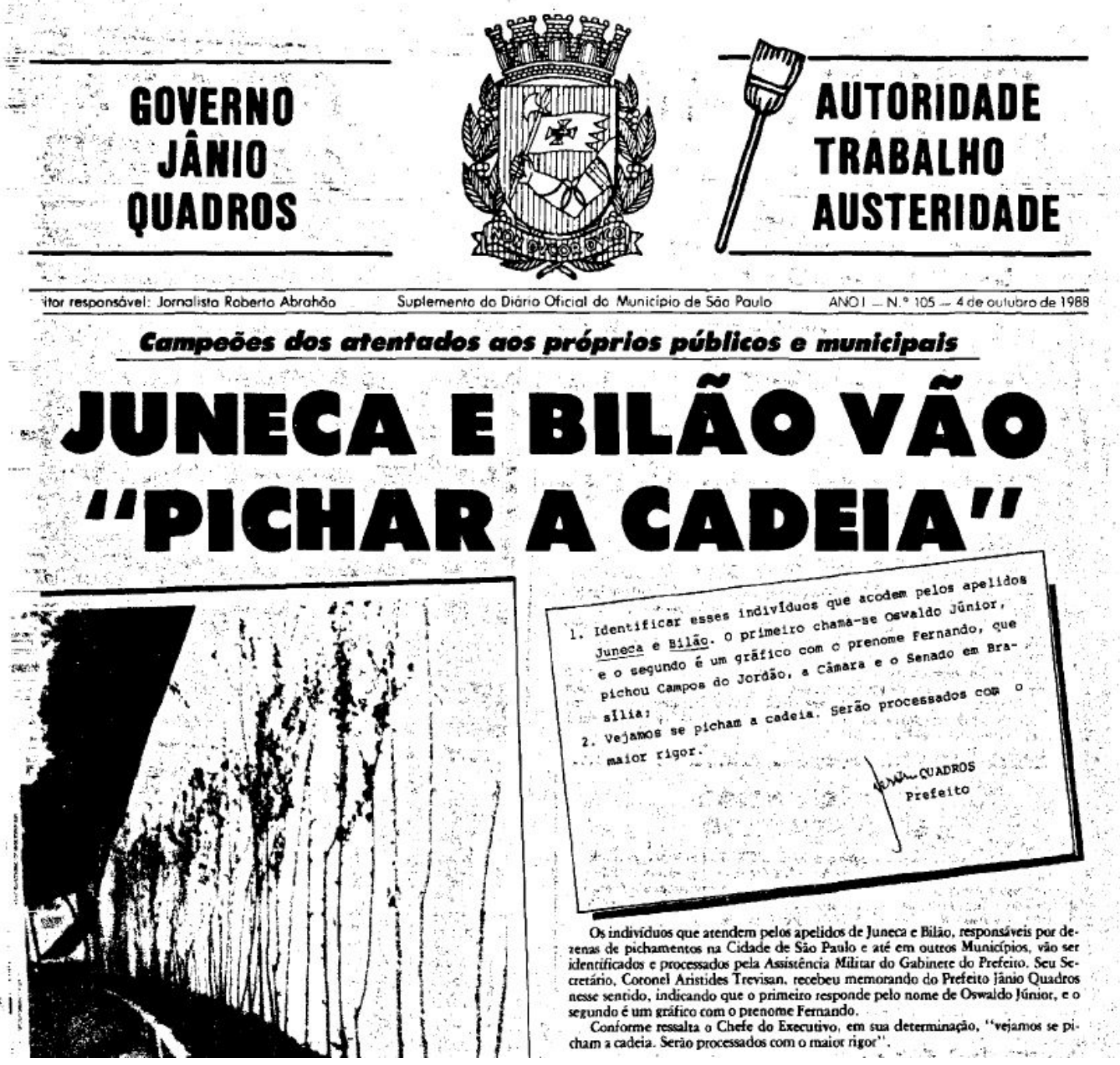

Fig.8: Capa do Diário Oficial de São Paulo de 4 de Outubro de $1988 \mathrm{com}$ memorando do prefeito Jânio Quadros falando sobre os pichadores Juneca e Bilão.

Em 9 de março de 2009, a marca51 de "Pixo" TUMULOS começou a publicar na internet uma série de entrevistas com pichadores pertencentes ao movimento do "Pixo" com o seguinte mote:

\footnotetext{
${ }^{51}$ Marca é o nome dado ao nome inscrito por um grupo de pichadores. Por vezes o grupo que inscreve esta marca é chamado genericamente de "Gangue" esse nome não indica que os participantes de uma gangue participe da alguma atividade ilegal (fora a própria pichação). Ao contrário dos graffiti de gangues de Philadelphia dos anos 1960, gangue é apenas o nome dado a um conjunto de pichadores que picha a mesma marca, o mesmo logotipo (por exemplo SUSTO'S ou SCORPION).
} 
"Esse projeto das entrevistas com os pixadores aqui no nosso site é uma forma de nós mesmos pixadores sabermos a história de outros pixos, contadas pelos próprios caras. Diferente do que acontece em revistas ou fanzines, ou o que seja, aqui será publicado no site o que o entrevistado respondeu, sem acrescentar uma só vírgula. Isso para evitar o que acontece em jornais quando os caras acabam publicando o que 'eles' querem publicar, ok?".

Desde a primeira entrevista com THE RELAMPAGOS até a última, publicada em 5 de fevereiro de 2010, com Djan da gangue CRIPTA, está disponível na internet um extenso catálogo de quarenta e quatro entrevistas com diversos pichadores, predominantemente de São Paulo, que segue um número padrão de perguntas, como; o ano em que o entrevistado começou a pichar, qual o motivo do nome da marca ou apelido de muro do pichador, o que é pichação etc. Para apresentar os entrevistados o entrevistador geralmente se refere a eles: "um dos pixos mais antigos", "um dos pixos mais polêmicos", "um dos mais famosos pixos de São Paulo". Uma das entrevistas apresenta o entrevistado como "Juneca, um dos pioneiros da pixação em SP" ${ }^{52}$

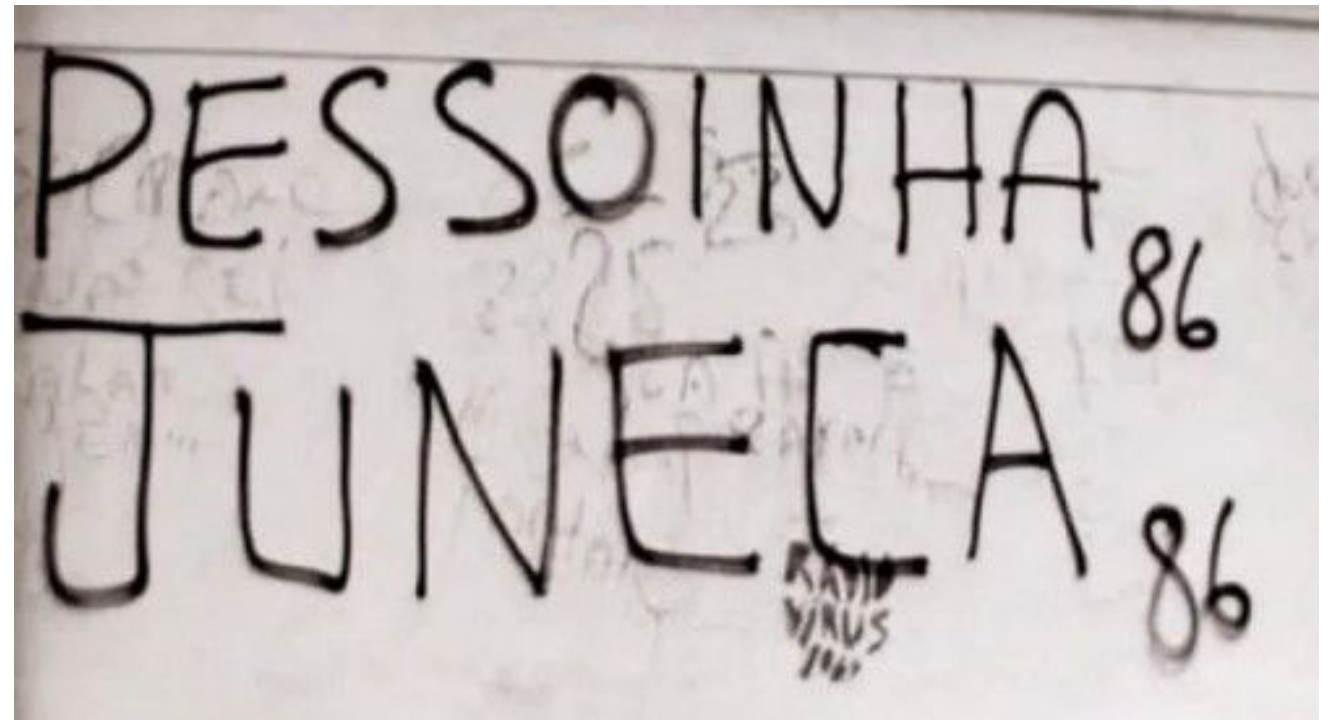

Fig. 9: Pichação de JUNECA e PESSOINHA datada de 1986.

Apesar de Juneca ter começado a pichar depois do início da prática das "Pichações poéticas" dos anos setenta, nem ele nem os "Pixadores" costumam

\footnotetext{
52 Entrevistas do Caixão \#34. Publicada em 25 de setembro de 2009.

http://entrevistastumulos.blogspot.com.br/2009/09/juneca-entrevista.html Acessado em 25 de setembro de 2017.
} 
fazer qualquer referência a elas. Seus ataques aos muros da cidade junto com Pessoinha, seu parceiro de pichação, hoje advogado, surgiram: "No começo dos anos 80 , começou tudo por brincadeira, e foi tomando dimensões aguçando a curiosidade das pessoas por muitos anos." ${ }^{\text {"53 }}$. A pichação de Juneca e Pessoinha ainda não apresentava todos os traços característicos do "Pixo" como o conhecemos hoje, como as letras angulares de difícil leitura para os não iniciados, ocupando desde os muros mais acessíveis até os viadutos que cortam as marginais e topos de prédios. É amplamente reconhecida por ser uma das primeiras pichações dessa vertente. Na entrevista para o site do TUMULOS, Juneca descreve como era a pichação na época em que começou seu trabalho: "Não existia praticamente pixação, somente algumas frases de efeito e o lendário cão fila km. Com certeza, por esta razão, tivemos tanto destaque que dura até hoje.". As frases de efeito a que Juneca se refere podem muito bem ser o que se chama aqui de "Pichação poética", que, diferentemente do tag nova-iorquino e do "Pixo", costumava trazer pequenas frases.

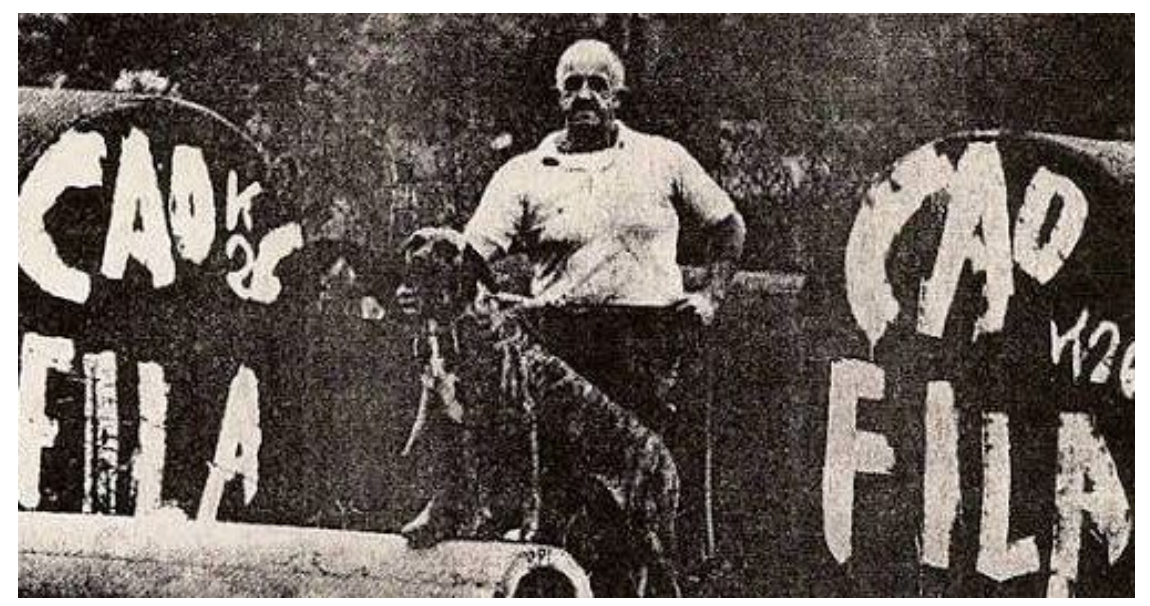

Fig. 10. O "lendário cão fila" de "Tozinho" em fotografia para a revista Veja de 6 de julho de 1977.

Uma reportagem publicada na revista Veja em 6 de Julho de 1977 apresenta a figura por trás do "lendário cão fila" referido por Juneca na entrevista. A entrevista

\footnotetext{
${ }^{53}$ Entrevistas do Caixão \#34.
} 
também ajuda a identificar o que há em comum entre as pichações de Antenor de Lara Campos e as pichações dos "Pixadores"; "Muros, pontes, viadutos, postes, mourões, pedras, barrancos - praticamente não há superfície sólida no país a salvo da rústica, enigmática inscrição 'Cão fila km 26". ${ }^{54}$ A diferença é que Antenor, também conhecido pelo apelido "Tozinho", fazia as inscrições com o propósito de vender os cães da raça Fila brasileiro que ele criava no quilômetro 26 da Estrada do Alvarenga em São Bernardo do Campo. A principal referência de "Tozinho" para sua tática de propaganda era a pintura de muros para a propaganda política: "na verdade, baseei-me nas campanhas eleitorais de Adhemar de Barros. Até hoje ainda se encontra o nome dele pintado em pontes e lugares semelhantes".

${ }^{54}$ Revista Veja, 6 de julho de 1977. 
"CELACANTO PROVOCA MAREMOTO", primeira pichação carioca. Antes disso, houve inscrições de protesto nos muros contra a ditadura, mas expressão como é percebida nos dias atuais, começa na repercussão acontecida a partir dessa e de outras frases surgidas nos muros de Ipanema e Leblon, na Zona Sul do Rio. Seria uma banda de rock, subversivos, extraterrestres ou traficantes?". ${ }^{55}$

O Pixo paulistano não é, evidentemente, o único exemplo de regionalismo na escritura mural brasileira. Com maior ou menor grau de particularidade visual, a pichação praticada em outras grandes cidades tem suas especificidades locais. "Xarpi, inversão da palavra pixar. O vocábulo faz parte da linguagem em código criada nos anos 80 pelos pixadores cariocas a fim de não serem compreendidos por quem não era iniciado nessa prática", ${ }^{56}$ como Indica Dani Dias, a responsável pelos textos do livro Xarpi, que apresenta a pichação carioca: "um olhar mais atento percebe que o pixo carioca, por exemplo, possui tipografia e caligrafia com estilos únicos, diferente da pixação de outra metrópoles, como São Paulo, Paris ou Nova lorque", ${ }^{57}$ qual seria essa diferença de estilo em relação ao Pixo paulistano?

Ao observar as imagens do livro Xarpi, que apresenta ininterruptamente 1368 fotografias de Xarpis, uma diferença de técnica relativamente ao Pixo se torna clara. Nenhuma dessas pichações ao estilo carioca parece ter sido feita com a técnica corrente em São Paulo, a do Pixo de tinta látex e rolo. As marcas do letreiro paulistano, conhecido por suas linhas retas e ângulos agudos, por seu caráter "tipográfico", definido aqui pela separação individualizadora das letras individualmente em oposição à continuidade do caráter "caligráfico" em um letreiro onde elas se seguem por uma ligatura. O Pixo de caráter tipográfico pode ser dimensionado limitado apenas pela grossura do rolo de tinta, suporte e pelo comprimento do extensor que aumenta o alcance dos traços do pichador. O Xarpi, por este seu caráter caligráfico, além de apresentar um estilo cheio de voltas e

\footnotetext{
${ }^{55}$ MARCELO, João. Xarpi: Um Registro Sobre a Pixação no Rio de Janeiro / João Marcelo 1a ed. Rio de Janeiro: Edição do Autor, 2015. Pág. 13.

${ }^{56}$ MARCELO, João. Xarpi: Um Registro Sobre a Pixação no Rio de Janeiro / João Marcelo 1a ed. Rio de Janeiro: Edição do Autor, 2015. Pág. 11.

${ }^{57}$ MARCELO, João. Xarpi: Um Registro Sobre a Pixação no Rio de Janeiro / João Marcelo 1a ed. Rio de Janeiro: Edição do Autor, 2015. Pág. 11.
} 
ligaturas, muitas vezes reminiscente do tag nova-iorquino, está limitado ao comprimento do braço que escreve, quase sempre utilizando o spray ou caneta marcadora, é limitado na grossura pelo bico do spray ou feltro da ponta da caneta. Um icônico ataque do Xarpi mostra as pichações feitas nas 4 faces do topo do relógio da Central do Brasil. ${ }^{58}$ Por seu caráter caligráfico, o ataque de Xarpi preencheu cada um dos nichos da torre com uma pichação individual, posto que se o mesmo ataque tivesse sido feito por um praticante do Pixo, muito provavelmente cada nicho guardaria apenas uma das letras da escritura inteira. Assim, não apenas as diferenças matriciais delimitam o formato e estilo de cada prática, mas elas também são necessariamente definidas pelas técnicas específicas.

${ }^{58}$ Xarpi, Pág 24. 


\section{A dinâmica nos grupos paulistanos}

\subsection{Agonismo e Destruição}

O documentário americano Style Wars de 1983, dirigido por Tony Silver e produzido em colaboração com Henry Chalfant (co-autor dos livros Subway Art e Spraycan Art, anteriormente indicados como importante referência para a produção do "Graffiti nova-iorquino" como praticado no Brasil), apresenta uma visão ampla de como era a cena do graffiti em Nova lorque no começo dos anos 1980. Como o nome do documentário sugere, Style Wars trata sobre como o desenvolvimento do "Graffiti nova-iorquino" se deu através da disputa entre seus praticantes, especialmente através das pinturas feitas no suporte móvel do sistema metroviário da cidade americana. Aos $5 \mathrm{~min} 18 \mathrm{seg}$ do começo do filme, os documentaristas entrevistam o grafiteiro Skeme, na época com apenas 17 anos, e sua mãe Barbara. Ao ser questionado por sua mãe sobre qual seria a validade de se preocupar com grafitar tantas linhas de metrô uma vez que, mesmo assim não era conhecido, Skeme dá uma explicação sucinta:

"É uma questão de conseguir um tag em cada linha e cada divisão. Sabe, chama-se ir all-city [cidade inteira]. As pessoas vêem seus tags no Queens, Uptown, Centro -em todos os lugares... Eu não ligo se ninguém mais está vendo ou no fato de deles conseguirem ler aquilo ou não. É para mim e para os outros escritores de graffiti, nós conseguimos ler. Todas essas pessoas que não escrevem [graffiti], estão excluídas. Eu não ligo pra elas, sabe? Elas não importam para mim. É pra gente". ${ }^{59}$

Este traço, da produção feita visando a um público interno ao próprio grupo, já foi indicado aqui nas distinções apresentadas por Cedar Lewisohn entre "Graffiti writing" e "Street art", sendo o primeiro voltado para a identificação e reconhecimento do próprio grupo e o segundo visando a um público geral. O que uma produção voltada para um público especializado com suas próprias regras de

\footnotetext{
${ }^{59}$ Style Wars "It's a matter of getting a tag on each line and each division. You know, it's called going all-city. People see your tags in Queens, Uptown, Downtown- all over... I don't care about nobody else seeing it, or the fact if they can read it or not. It's for me and other graffiti writers, that we can read it. All these other people who don't write, they're excluded. I don't care about them, you know? They don't matter to me. It's for us".
} 
valoração cria é um grande campo comum, que consegue definir regras específicas que ditam onde há excelência na prática. Um termo usado por François Chastanet em seu Pichação: São Paulo signature remete a essa noção interna; ele chama de "uma aristocracia de escribas vândalos" ao se referir ao Pixo paulistano, e essa noção de aristocracia se produz pelo conjunto interno de valoração da prática, que exclui quem é de fora. Tanto o "Graffiti internacional" quanto o "Pixo" tem um termo próprio para definir o mau praticante, respectivamente, "Toy" e "Bafo". Como quase todos os termos usados no Brasil no âmbito do "Graffiti internacional", o termo "Toy" foi importado de Nova lorque, o termo "Bafo"' do Pixo como a própria prática, é de cunho Paulistano.

O que uma definição estrita de técnica, procedimento, suporte e qualidade cria é um campo comum, onde a valoração de uma pintura é dada de acordo com a obediência a esses preceitos, além do julgamento de cada pintura de acordo com as qualidades norteadoras de cada grupo. Um grande mural de graffiti pintado com dezenas de latas de spray durante uma tarde inteira será valorado de maneira diferente de um "Pixo" feito em 3 minutos no topo de um prédio com rolo e extensor. De maneira geral, um graffiti feito em São Paulo nos moldes americanos é qualificado de acordo com, entre outros valores, sua proeza técnica e variedade nos moldes internos à produção do "Graffiti internacional". Para a disputa entre iguais, onde as regras estabelecidas dão a possibilidade da valoração de seus trabalhos, buscando através da qualidade do próprio trabalho a superação de seus iguais, dou o nome de agonismo. Esta é uma das principais forças motrizes que fez o "Graffiti internacional" se desenvolver, posto que, como podemos ver na voz de Skeme acima, o "Graffiti internacional" não se preocupa necessariamente (ao menos em suas fases iniciais e em sua forma mais purista) com a aceitação do público externo. Pois, não foi a busca por uma aceitação externa que levou o graffiti a se desenvolver técnica e estilisticamente. Além dos termos próprios da pintura, proeza técnica e estilística na produção de um bom letreiro, de um bom personagem, outros valores se acrescentam à produção do graffiti (e da pichação), como a dificuldade da pintura em um suporte proibido. Uma comparação é relevante para se enxergar 
como algumas mudanças de ambiente alteram o resultado de uma produção local de graffiti nos moldes americanos. 


\subsubsection{O Suporte Móvel}

É reconhecido o fato de o "Graffiti nova-iorquino" ter seu desenvolvimento associado à pintura de trens de metrô desde a década de 1970, como o próprio nome de alguns livros que tratam do tema denotam; o livro de Jack Stewart diz claramente seu objeto no subtítulo Graffiti Kings: New York City Mass Transit Art of the 1970s, e o primeiro livro de Martha Cooper e Henry Chalfant sobre o movimento não se chama "Graffiti de Nova lorque" ou algo semelhante, mas apenas Subway Art. O documentário Style Wars nos dá uma boa visão geral de como se dava a disputa entre os grafiteiros que, por pintarem no suporte móvel do metrô, conseguiam acompanhar o que os seus iguais pintavam em uma região distante da cidade, esperando apenas os trens passarem com as novidades pintadas em suas superfícies. A malha metroviária de Nova lorque ajudou em muito a disseminação do graffiti: quando uma novidade era apresentada pintada no exterior de um carro do metrô, ela era desfilada através de toda a extensão de sua linha, para ser observada, copiada, transformada, atacada e desenvolvida. Ao invés de um regionalismo isolado nos bairros (boroughs), a disputa generalizada na região metropolitana de Nova lorque forçou os praticantes a melhorarem seus trabalhos em relação aos de seus iguais. O metrô era a veia pela qual o agonismo corria, fazendo o graffiti se aperfeiçoar.

Observando os trens do metrô de São Paulo, que em sua maior parte ostentam o brilho de sua fuselagem prateada ou as multicoloridas publicidades coladas a seus exteriores, é possível imaginar que esse suporte nunca tenha sido visado pelos praticantes do "Graffiti internacional" daqui, o que todavia, não é verdade. A orientação nos metrôs da cidade de São Paulo é a de não se colocar os carros de metrô vandalizados em circulação, não apenas para se permitir a limpeza que tira todos os traços dos graffiti inscritos em sua superfície externa, mas também para não se incentivar a prática da pintura ilegal. Existe, aliás uma publicação chamada LATEX que mostra exclusivamente registros de graffiti feitos nos trens de metrô de São Paulo. Diferentemente do graffiti dos anos 1970 e 1980 feitos em Nova lorque, que circulavam a cidade inteira fomentando a disseminação e a 
disputa entre os praticantes, os graffiti nos trens de São Paulo são vistos basicamente por dois grupos, os próprios grafiteiros que fazem as pinturas e os funcionários do metrô que as combatem. Uma pintura ilegal que depende da invasão dos pátios onde os trens passam a noite, da evasão dos agentes de segurança do metrô (apelidados de "Urubus" em virtude de seu uniforme preto), do perigo de serem presos e acusados de crime ambiental, além do risco adicional de depois de terminadas as pinturas precisarem gastar ainda mais tempo para registrá-las em fotografia, correndo mais risco ainda de serem pegos. E qual seria o objetivo de passar por todas essas dificuldades se quase ninguém pode reconhecer, ou sequer ver essas pinturas? Assim como Skeme disse acima, o objetivo é o reconhecimento dos iguais, que entendem não apenas o valor da pintura em si, mas todas as barreiras que precisaram ser ultrapassadas para ela ser feita. 


\subsubsection{Destruição}

O mesmo sentimento de disputa nascido em Nova lorque veio para São Paulo, como Onesto declara em sua entrevista para esta pesquisa:

"Sempre acreditei nisso, isso que fazia a coisa ficar divertida, você saía pra rua pra quebrar o cara que tá saindo junto com você, pra quebrar o cara que você viu. Hoje não, todo mundo, 'ai, não vou fazer nada alí.". 60

Essa pulsão por uma melhora em seu próprio trabalho não se manifesta apenas em uma necessidade individual de aprimoramento, mas por uma disputa entre você e os seus. Se um público geral não reconhece e até mesmo criminaliza a empreitada que passa pelo risco de ser pego pela polícia, pelo aperfeiçoamento técnico, pelo custo monetário (especialmente quando se trata da tinta em spray, que nunca foi um material barato), pelo tempo, entre outros custos associados; a aceitação e o reconhecimento do trabalho pelos iguais demonstra-se extremamente importante. Diferentemente de um artista criado nos moldes da educação formal, o grafiteiro aprende através do que ele próprio enxerga enquanto vivente nos muros e nos exemplos práticos de seus colegas, relação que embora a princípio hierarquizada, logo horizontaliza-se quando todos se enxergam como iguais.

Diferente do um artista da educação formal, que muitas vezes tem o norte de seu trabalho nos cânones das artes e artistas 'consagrados' nas listas da história da arte, o grafiteiro tem em seus iguais o metro de seu trabalho, o exemplo frente o qual cotejar seus próprios feitos de técnica, originalidade, autenticidade e respeito. $A$ relação de aperfeiçoamento de um grafiteiro que segue o modelo nova-iorquino, se dá inicialmente com os exemplos auto-referenciais do grupo no padrão "Graffiti internacional", disso se segue a unidade estilística do graffiti praticado no mundo. Porém, a agonística não é a única força que opera na vivacidade dos graffiti de São Paulo, ou no mundo. Em contraste com ela coloca-se outra, a que ignora qualquer

\footnotetext{
${ }^{60}$ Entrevista com Onesto para esta pesquisa.
} 
noção de disputa entre iguais, a que ignora a própria validade das práticas mesmas. A isso chamo de destruição.

A destruição prescinde da equiparação, ela sequer precisa reconhecê-la, pois opera para lá da troca possibilitada pela disputa entre iguais. Ela pode ser uma relação assimétrica de forças, agindo através de apagamentos, censuras, rasuras, deturpações. Não necessitando do campo comum, a destruição se dá entre diferentes grupos e instituições, e não implica o desenvolvimento do graffiti, ou pichação, em direção a uma clara melhora, como pode ser o movimento impulsionado pelo agonismo. Porém, ela é tão ou mais importante do que este para o desenvolvimento do graffiti, e da pichação. 
Em Janeiro de 2007, entrou em vigor na cidade de São Paulo a lei Cidade Limpa. Com a finalidade de diminuir a poluição visual na cidade, a lei proibiu o uso de outdoors em território urbano, limitou o tamanho máximo dos letreiros comerciais e também deu continuidade renovada ao trabalho de apagar os graffiti e pichações dos muros da cidade. Em 3 de julho de 2008, um grande mural que existia na avenida 23 de Maio foi apagado por uma empresa terceirizada pela prefeitura de São Paulo. O mural era formado por imensas pinturas de Nina Pandolfo, Os Gêmeos, Vitché, Herbert Baglione e Nunca. A ação produziu intensa comoção entre admiradores, grafiteiros e artistas, causando até mesmo uma retratação por parte da prefeitura de Gilberto Kassab ${ }^{61}$ que alegava que "os Servidores das empresas terceirizadas responsáveis pelo serviço não tem o conhecimento técnico necessário para diferenciar o que é manifestação artística do que é dano ao patrimônio". ${ }^{62}$

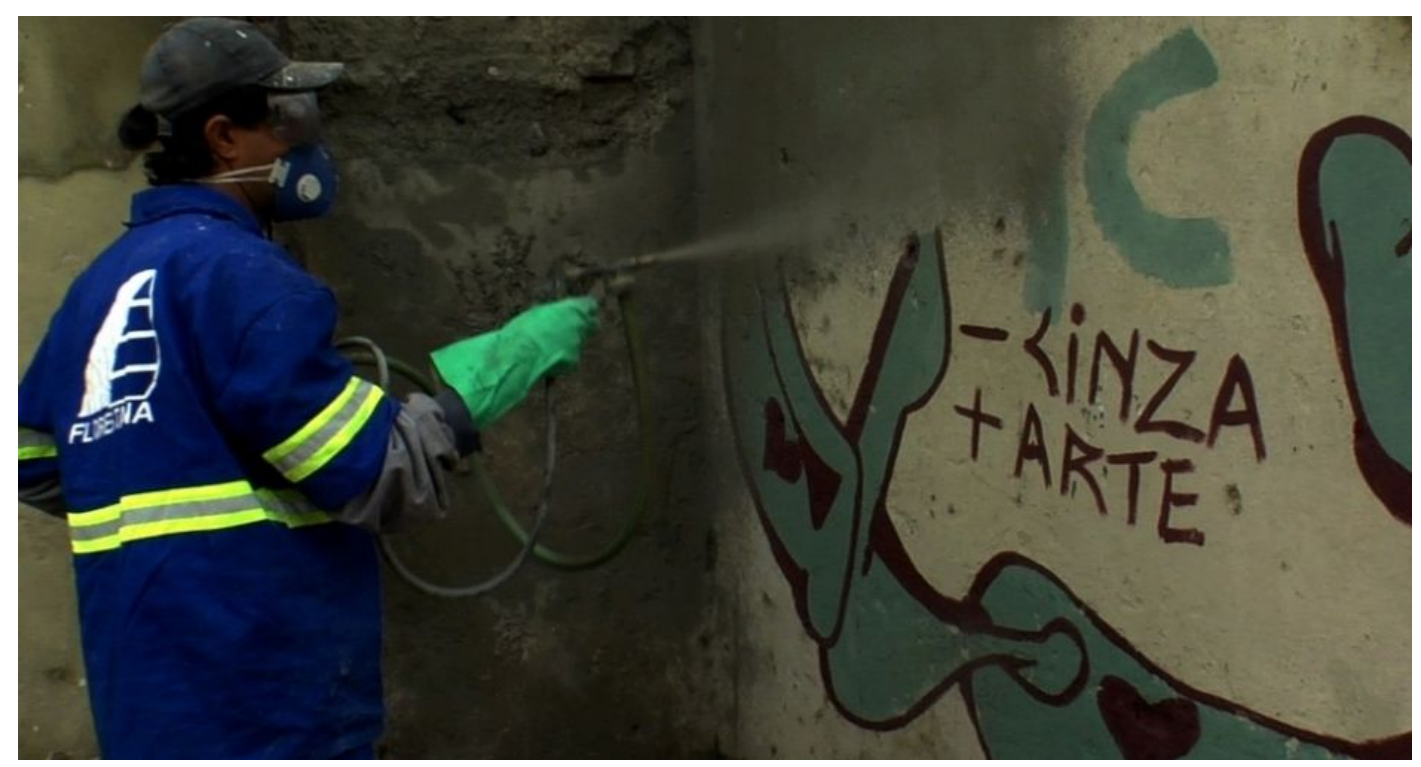

Fig 11. - Imagem do documentário Cidade Cinza mostrando uma equipe terceirizada pintando os muros da cidade.

\footnotetext{
6127 de Julho de 2008, Folha de São Paulo, matéria de Juliana Nadin.

62 Essa declaração é de 2014, feita para matéria de Regiane Teixeira para a Folha de São Paulo, mas o discurso costuma ser o mesmo, desde o começo das ações da Cidade Limpa.
} 
O documentário Cidade Cinza $^{63}$ de 2013, dirigido por Marcelo Mesquita e Guilherme Valiengo, acompanha dois distintos grupos empenhados em pintar os muros da cidade de São Paulo. De um lado Nina, Os Gêmeos e Nunca, que trabalham pintando de novo um mural que havia sido coberto de cinza pelos agentes da Cidade Limpa, e de outro um grupo desses mesmos agentes, enquanto andam com sua Kombi pela cidade apagando muros pichados e grafitados. $\mathrm{O}$ documentário mostra a arbitrariedade da escolha, pelos trabalhadores terceirizados, do que deve ou não ser apagado, em contraste com o crescente reconhecimento internacional de alguns artistas que se formaram a partir do "Graffiti internacional" como praticado em São Paulo. Um exemplo que pode enriquecer a definição dessa relação assimétrica de interferência e força é a ação da Prefeitura de São Paulo sobre um graffiti de Whip.

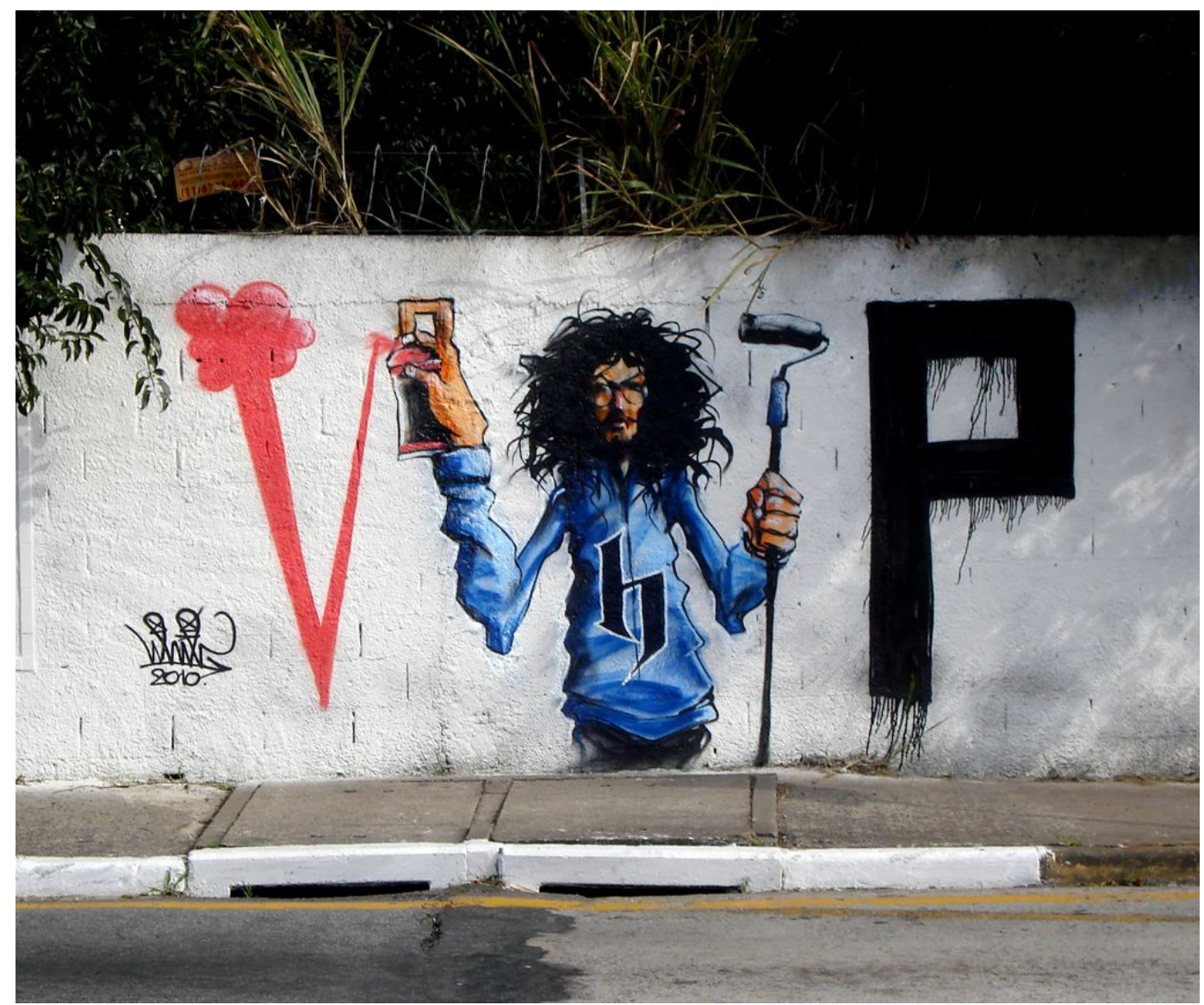

\footnotetext{
${ }^{63}$ Desde o começo das ações da Cidade Limpa o apelido Cidade Cinza tem sido usado, como referência ao tom cinza da tinta que cobre as pichações e graffiti apagados.
} 
Fig. 12 - O autorretrato de Whip que foi alvo da lei Cidade Limpa.

Um exemplo em menor escala da relação de destruição causada pelas ações da Cidade Limpa ocorreu com um graffiti feito pelo grafiteiro e artista Whip, que por volta do ano de 2010, pintava autorretratos variados nos muros da cidade de São Paulo e, ao menos em uma ocasião, Buenos Aires. Não eram meras repetições da mesma figura, em cada pintura o grafiteiro testava novas poses e estilos de figuração, mas um graffiti em especial, pintado na Avenida Doutor Arnaldo (Fig. 4), se destacou não apenas pela composição distinta - nela os elementos pintados compunham a sua assinatura W H I P- mas especialmente pela ação dos pintores da Cidade Limpa, que costumeiramente cobrem o muro onde este autorretrato foi pintado. Vê-se na segunda imagem (Fig. 5) como ficou o graffiti de Whip depois da ação da Cidade Limpa. Com a orientação de apagar as pichações e deixar os graffiti intactos, os pintores da Cidade Limpa apagaram as partes do graffiti que tinha mais "traços de pichação" e deixaram a parte central, figurativa, intacta.

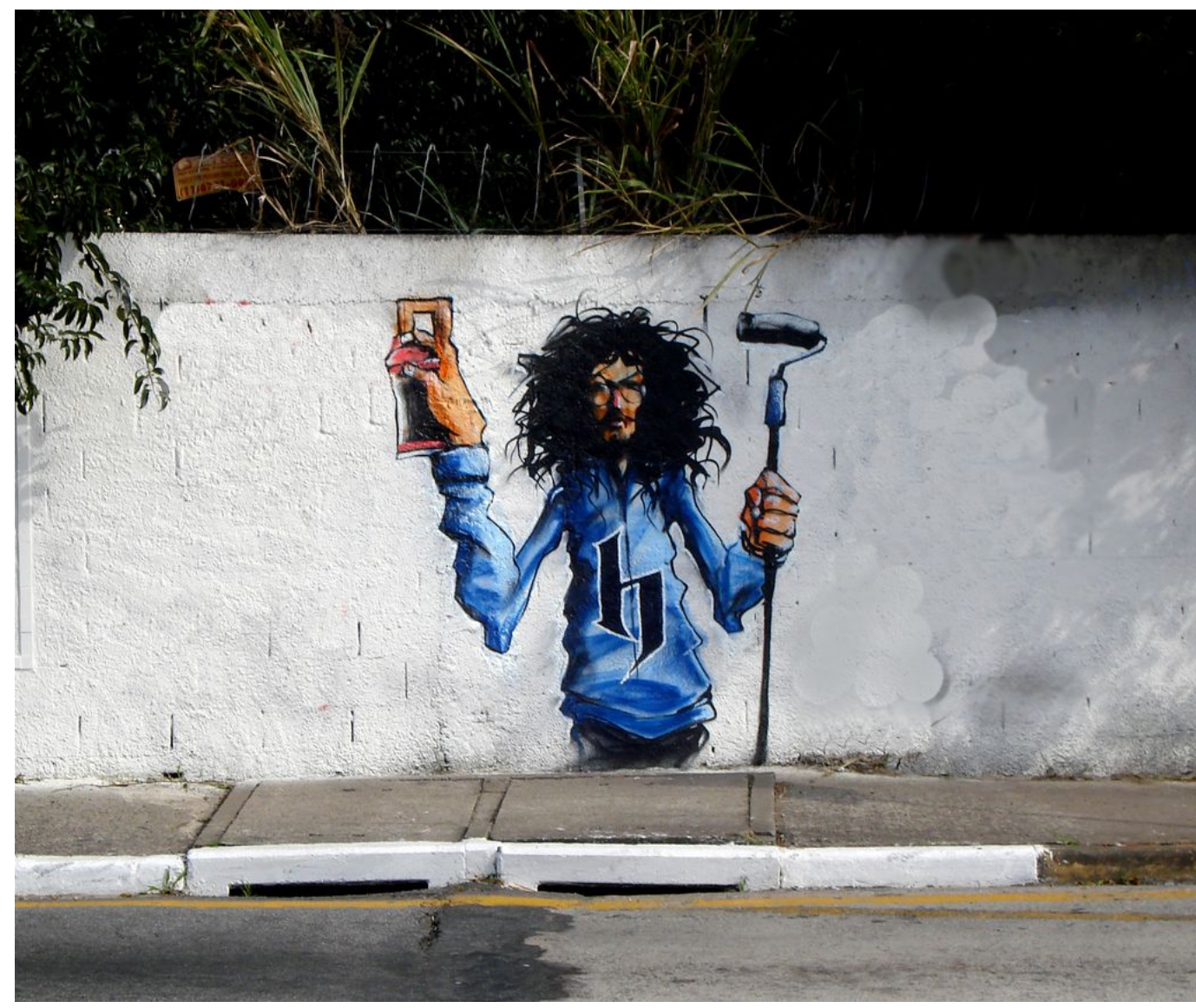


Fig. 13 - Simulação do autorretrato de Whip após a intervenção da Cidade Limpa (não foi possível encontrar uma reprodução fotográfica).

Quando questionados sobre como a lei Cidade Limpa deveria atuar, a maior parte dos grafiteiros e pichadores concorda: "ou apaga tudo, ou não apaga nada", como o grafiteiro e artista Tinho declarou em uma conversa sobre o começo do "Graffiti internacional" em São Paulo. ${ }^{64}$ Alguns dos defensores do graffiti paulistano, enquanto patrimônio artístico e cultural da cidade de São Paulo, defendem que essas pinturas deveriam ser protegidas de intervenções externas e costumeiramente restauradas. Um exemplo dessa abordagem é a pintura de Rui Amaral no túnel que liga a Av. Paulista à Av. Doutor Arnaldo, que já há alguns anos permanece relativamente intocada por intervenções externas, como pichações e outros graffiti. É comum imaginar que apagar as pinturas e escrituras murais é necessariamente ruim para seus praticantes, mas nem sempre isso é assim. Em conversa com Onesto, este apresentou um problema curioso, diferente do colocado na questão do "apagar ou não": "Apagar pichação e deixar graffiti, eu acho zoado, não tem a ver, ou apaga tudo ou não apaga nada". Na mesma chave da declaração de Tinho, mas continua: "Houve uma época, na gestão Erundina [prefeita de São Paulo de 1989 a 1993], que não apagavam nada, não tinha mais espaço pra pintar". A efemeridade da pintura mural não autorizada não é vista apenas como um aspecto negativo, pois a constante luta por espaço no muro e contra as forças que apagam o que foi pintado, junto com a vontade de superar seu igual, são traços que possibilitaram o desenvolvimento do graffiti paulistano.

O que a mutilação da pintura de Whip evidencia é como uma definição externa a uma prática (ou do que ela deveria ser, segundo esta definição) pode suprimir uma parte de um objeto, enquanto ressalta uma outra. Um análogo à prática dos pintores da Cidade Limpa, é a omissão de traços que "não encaixam" em uma reconhecida obra de arte por parte de um estudioso e teórico de história da arte, em uma tentativa de classificar uma pintura em um padrão, fazendo assim o

\footnotetext{
${ }^{64}$ Em dicussão feita na Livraria Cultura do Conjunto Nacional em Novembro de 2015, gravada e transcrita para essa pesquisa.
} 
objeto encaixar-se na teoria ao invés de a mesma, dele partindo, tentar entendê-la como pintura que se apresenta ao mundo. 


\subsubsection{Transgressão, valor e destruição}

O caráter transgressivo dessas práticas é impositivo, opondo-se a pintura e a escritura não autorizadas à vontade do dono do muro, seja ele público ou privado -e esta noção é substancial para a própria definição do que é um graffiti ou uma pichação. Valor importante para uma pichação (que goza de menor aceitação popular do que o graffiti) é a sua permanência, o tempo que um Pixo consegue resistir à inevitável tinta que irá cobrir sua marca no muro que o suporta. Um traço que pode justificar a maior validade da permanência para um Pixo do que para um graffiti é que, diferente do segundo, um Pixo não tem o estilo de sua marca alterado com a passagem dos anos. Um grafiteiro desenvolve e refina a sua técnica através dos anos; dessa forma a pintura de um grafiteiro de anos atrás será possivelmente menos hábil tecnicamente do que uma feita depois. $O$ valor da permanência é substituído por outros no graffiti, pela proeza técnica e pela novidade estilística, acentuando as diferenças nos campos comuns de cada grupo. Mesmo neste, os indivíduos tem especializações e valores próprios, como podemos ver na declaração de Cap (figura central no documentário Style Wars) que funciona como espécie de antagonista no filme: "Especialmente comigo. O objeto é mais. Não o maior ou o mais lindo, mas mais. É tipo um trabalho pequeno em cada carro... é o que conta. Não um carro inteiro a cada 30 que passam. Quando você começa a atropelar ${ }^{65}$ alguém, não dá pra parar. Então eu vou viver". ${ }^{66}$

\footnotetext{
${ }^{65}$ Atropelar é o termo usado tanto por grafiteiros quanto pichadores no Brasil para designar quando alguém pinta ou escreve em cima do trabalho de outro grafiteiro ou pichador.

${ }^{66}$ Style Wars no original em inglês:"Especially with me. The object is more. Not the biggest and the beautifullest, but more. It's like a little piece on every car...is what counts. Not one whole car on every 30 cars that goes by. Once you start going over someone, you can't stop. So, I'm gonna live".
} 


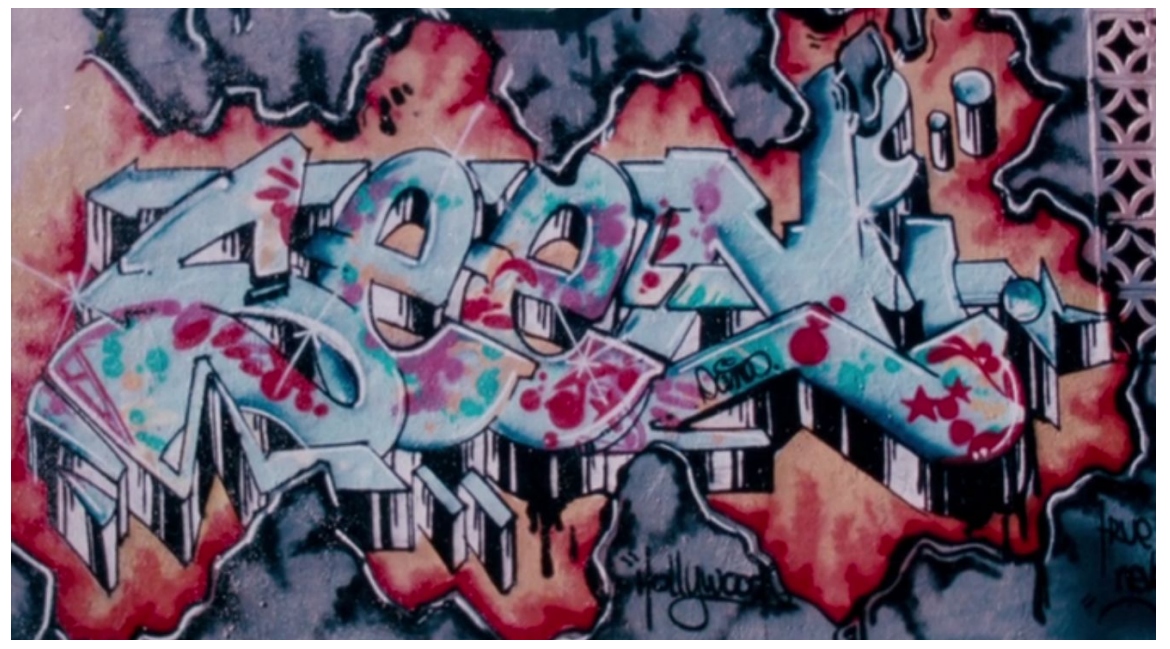

Fig. 14. Detalhe de um mural pintado em 1982 por Seen e o grupo de grafiteiros United Artists em uma tomada do documentário Style Wars.

"Aquela era uma parede linda. Eu realmente gostei dela. Pessoas assim merecem ter tudo que elas fizerem atropelado... pra sempre" ${ }^{67}$.

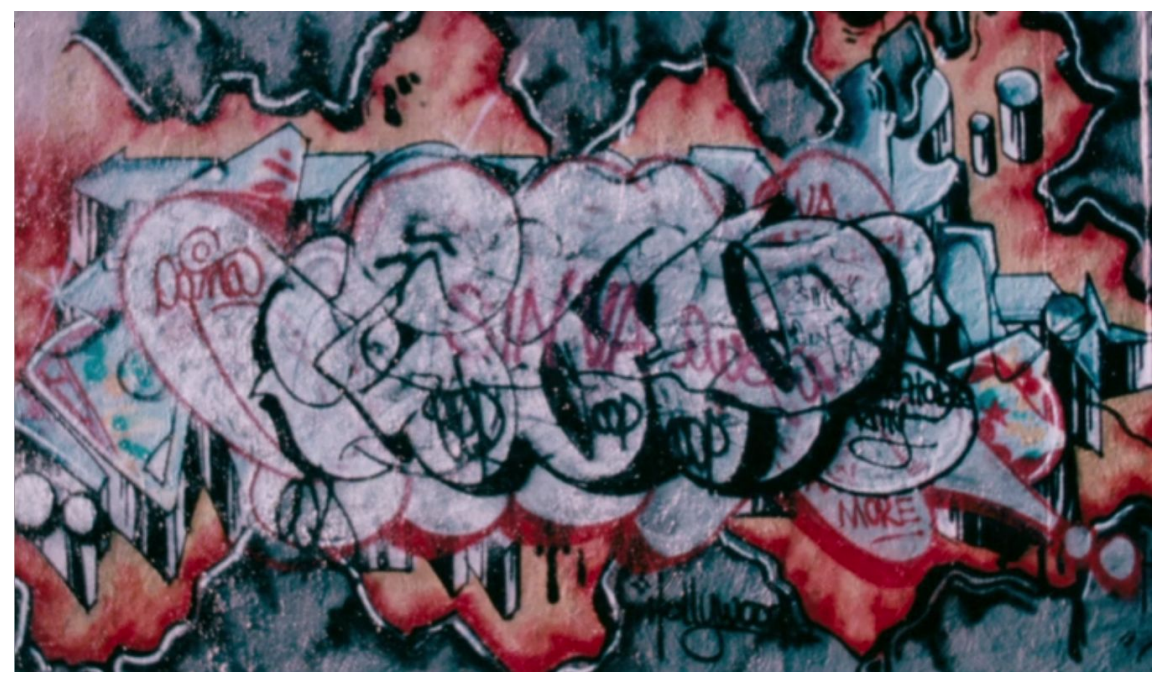

Fig. 15. O mesmo mural da figura acima depois que Cap o atropelou.

Não são apenas os praticantes de uma práticas, como no exemplo acima, que participam da esfera da destruição. Qualquer agente que apague, rasure ou atropele uma pintura ou escritura sem partilhar dos valores atribuídos à ela, é um agente da destruição. As relações de destruição podem ser mais ricas do que o mero apagamento ou censura total, como o nome dado para esta noção pode

${ }^{67}$ Style Wars no original em inglês: "That was a beautiful wall. I really liked that. People like that, they deserve getting everything they got crossed out... forever". 
sugerir. A rasura, censura pontual, deturpação e desfiguração; são todas internas às relações de destruição como essa noção é aqui apresentada. 


\subsection{Individuações}

"E essa mentalidade a gente foi passando pra todo mundo que veio depois da gente, todas as outras gerações até onde a gente teve contato, a gente sempre falava. 'Faz um estilo original, faz uma coisa própria, de preferência com informação do Brasil'. E isso foi o que fez o diferencial para o Brasil estar em uma posição de respeito e destaque, porque a gente quebrou a linhagem dos Estados Unidos. O graffiti em todo o mundo, até descobrirem a gente, era baseado no graffiti americano. O graffiti alemão era baseado no graffiti americano, o francês, inglês, holandês, todo mundo copiava o estilo americano". ${ }^{6}$

A quebra com a linhagem americana apresentada por Tinho, foi um movimento consciente dos grafiteiros paulistanos que vieram da própria matriz americana, mas a forma como cada um dos praticantes quebra com a tradição nova-iorquina é específica. Ao movimento em direção ao trabalho autoral dou o nome de individuação, posto que, partindo de um conjunto de regras de procedimento e exemplos visuais restritos, a busca se dá na direção de um trabalho distinto dos graffiti dos colegas. Um traço desse processo de individuação é a ampliação do campo comum do agonismo. Quanto mais distante das rígidas regras do "Graffiti internacional" tanto mais dificilmente um trabalho será valorado no conjunto dos exemplos visuais internacionais. Sem um metro claro de valoração, o graffiti praticado no Brasil a partir de meados da década de noventa, direcionado em grande parte pelos processos de individuação, recorre a dois movimentos básicos; a busca de referências externas ao "Graffiti internacional", assim como teste dos limites dessa prática.

A observação das diferentes dinâmicas de individuação, além de mostrar a particularidade de cada trabalho como um crescente valor entre muitos dos grafiteiros vindos da tradição do "Graffiti internacional", ajuda a identificar de que traços estão se afastando. Os elementos tradicionais do "Graffiti internacional" -a letra e a figura- são reavaliados e recolocados de maneira especialmente clara em dois exemplos de processos de individuação.

\footnotetext{
${ }^{68}$ Tinho em conversa na Livraria Cultura.
} 


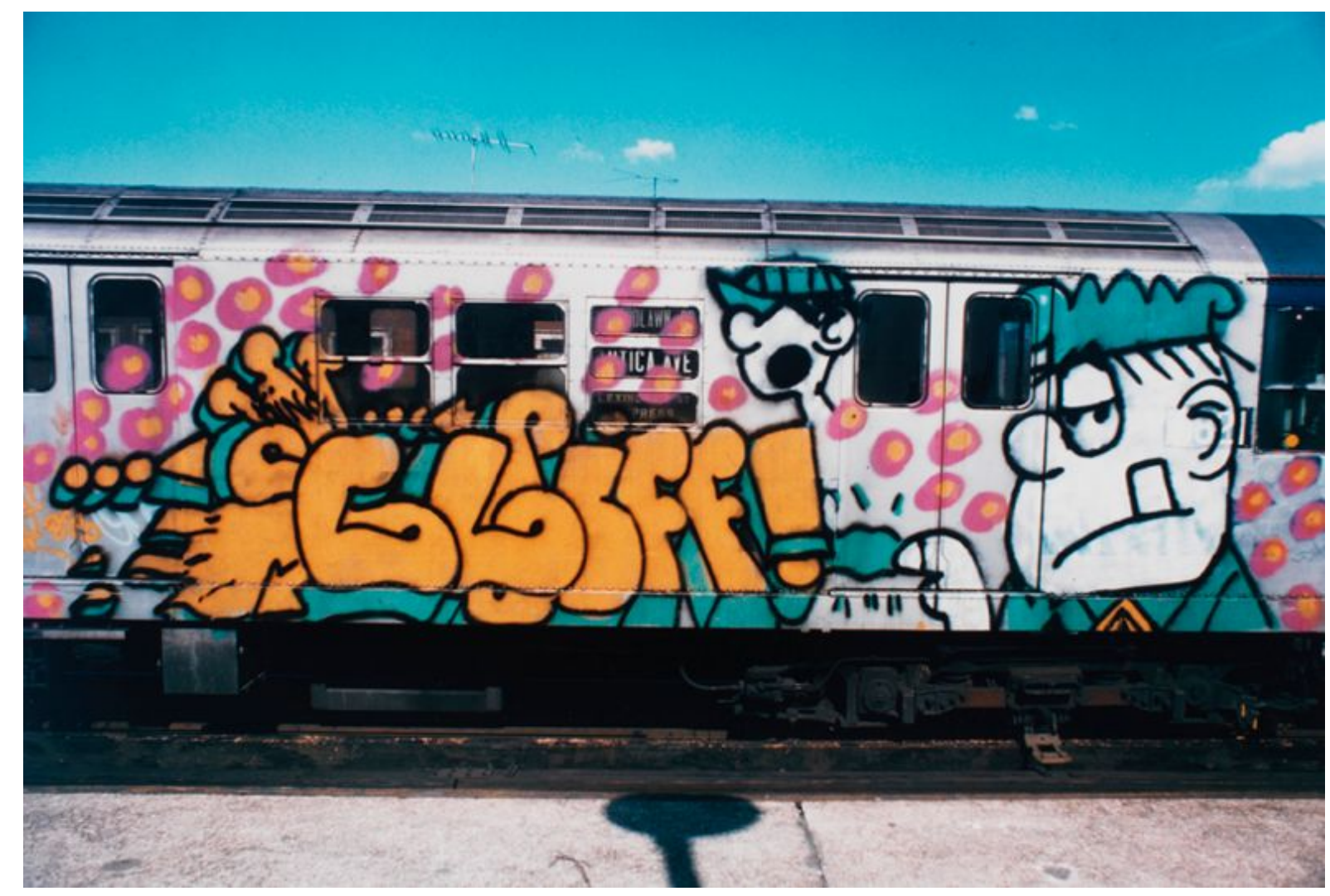

Fig 16. Graffiti feito por Cliff 159 e Peace em 1975, Nova lorque. Foto de Jack Stewart, $1975 .^{69}$

A prática de unir a pintura de letras com a de personagens pode ser traçada até as primeiras fases do "Graffiti nova-iorquino", como se pode ver nos diversos exemplos apresentados em Graffiti Kings. Porém, Jack Stewart dá uma informação mais precisa de quando essa prática começou a ser mais difundida:

"No outono de 1974. Cliff 159, um dos primeiros escritores de graffiti e membro do clube Wanted, começou uma série de 'pieces' apresentando personagens de tirinhas de quadrinhos de jornal. Embora outros escritores já tivessem desenhado personagens de quadrinhos antes, ele geralmente tomava inspiração de histórias em quadrinhos de que eles gostavam. Como as tirinhas de jornal eram voltadas ao público geral, Cliff deve ter mirado em um público mais amplo, como os fãs de Dick Tracy, Blondie e Recruta Zero". ${ }^{70}$

\footnotetext{
${ }^{69}$ STEWART, Jack. Graffiti Kings: New York City Mass Transit Art of the 1970s. Nova lorque, Abrams, 2009. P. 156-157.

${ }^{70}$ STEWART, Jack. Graffiti Kings: New York City Mass Transit Art of the 1970s. Nova lorque, Abrams, 2009. Pág. 154.
} 
O uso de personagens por parte dos praticantes do "Graffiti internacional" é tradicionalmente auxiliar da pintura de letras. A noção do grafiteiro enquanto primariamente pintor de letras é reforçada pelo termo "Graffiti writer" que podemos observar amplamente utilizado por autores como Cedar Lewisohn e Jack Stewart. O termo costuma ser utilizado no Brasil também com a tradução literal "Escritor de Graffiti". Os formatos do "Graffiti internacional" mais amplamente difundidos e reconhecidos durante os anos 1980, como o throw up e o wild style, são, essencialmente, formas de pintar letreiros. O personagem como auxiliar à letra ajuda a chamar os olhos do público geral para os letreiros como aponta Stewart na passagem acima, embora sejam frequentemente apresentados um ao lado do outro, como elementos da mesma pintura, mas distintos entre si. Embora não seja incomum o arranjo de elementos figurativos em grandes murais de graffiti, ou a inserção de pequenas figuras em throw ups ou até mesmo no Pixo, o que o brasileiro Salmos faz é a total fusão do "throw up" com o personagem.

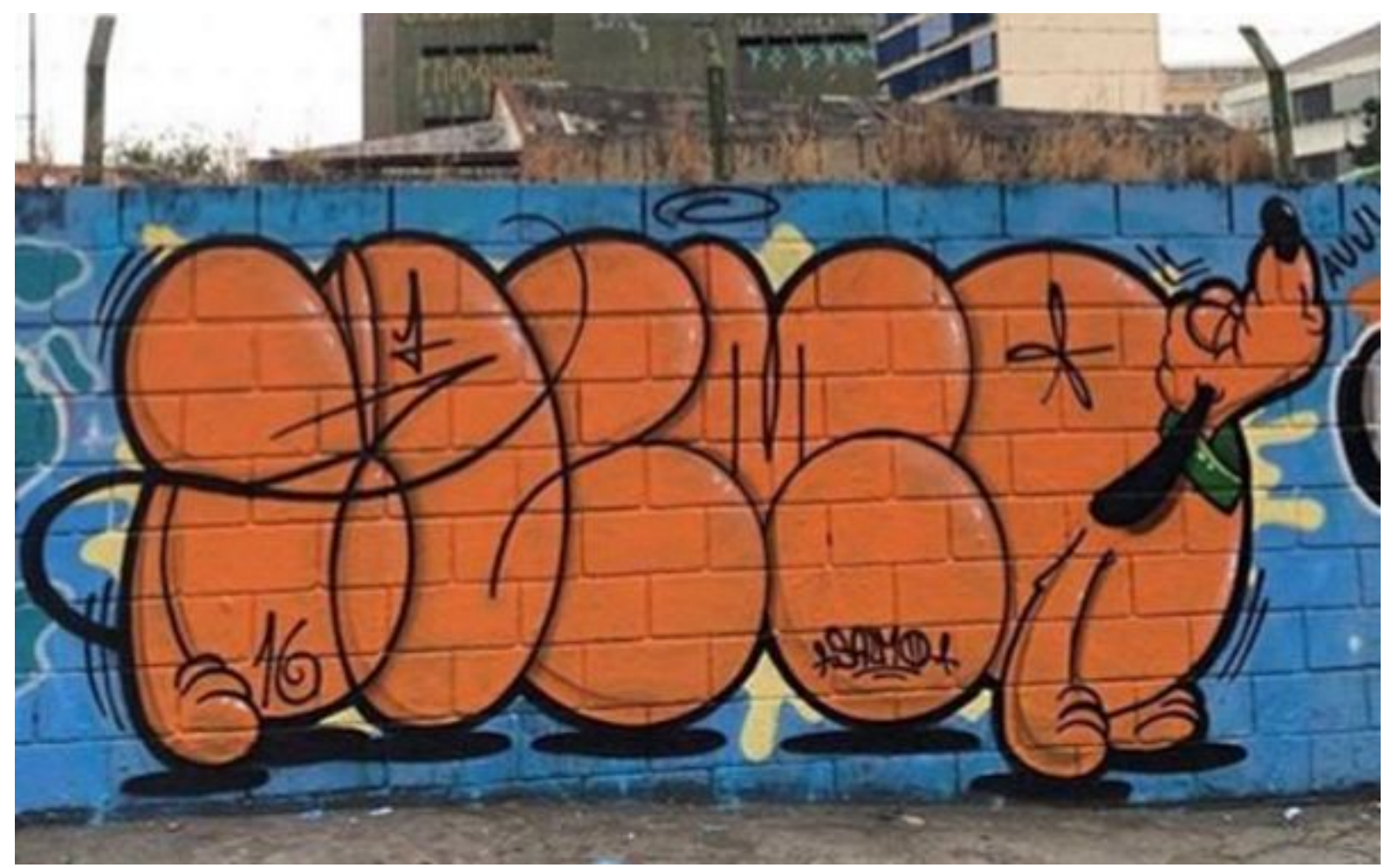

Fig. 17 - Graffiti de Salmos feito em 2016 em São Paulo, mesclando a figura com o formato das letras. Foto de Salmos, 2016. 
No release de imprensa de sua exposição em Nova lorque na galeria de arte Martinez, que aconteceu de 12 de Novembro até Dezembro de 2016, um pouco da trajetória de Salmos no graffiti é apresentada;

"Nascido no Brasil em 1982, SALMOS começou a pintar em 1997 na Zona Leste de São Paulo. Ele se considera um "bomber" ${ }^{11}$. Sendo pobre e desempregado, ele tinha problemas em conseguir materiais para pintar ou até mesmo fazer "pixação", uma das variações de graffiti paulistano (caligrafia essencialmente preta, monocromática composta de linhas retas e ângulos agudos). Como ele explica: 'Fat Caps ${ }^{72}$ eram um luxo. Nós usávamos rolinho e baldes de tinta que pegávamos em construções. A tinta em spray disponível era de uso automotivo, de qualidade muito ruim. Nós usávamos a graxa de sapato Nugget ${ }^{73}$ ao invés de canetas marcadoras. Achávamos paredes de construções abandonadas para pintar. Não tinhamos conhecimento de graffiti de outros lugares'. De 1998 a 2004, ele pintou trens de carga com o apelido ISHI. Em 2003 ele abriu seu próprio estúdio de tatuagem, de onde ele ganha o seu sustento. Em 2006 ele parou de grafitar, e em 2014 ressurgiu como SALMOS". ${ }^{74}$

O caminho de Salmos é parecido com o de muitos grafiteiros criados em São Paulo, mas o graffiti que ele começou a pintar a partir de sua volta às ruas em 2014, apesar de se fundamentar em dois elementos tradicionais do "Graffiti nova-iorquino", o throw up de letra de bolha e o personagem vindo das histórias em quadrinhos e dos desenhos animados, começou a mesclá-los de maneira particular. Na Fig. 2 é possível ver como os graffiti mais recentes de Salmos fundem os dois elementos do "Graffiti nova-iorquino", onde a figura do personagem se une completamente à pintura da letra. Mais elaborados do que um Throw up tradicional, que raramente é pintado com mais de duas ou três cores, ele segue o padrão de uma cor principal de preenchimento e um contorno nítido que demarca a separação das letras. A noção

\footnotetext{
${ }^{71}$ Em São Paulo um "bomber" designa o grafiteiro cujo trabalho principal é o "Throw up", "Bomb" no Brasil costuma ser sinônimo de "Throw up".

72 Fat Cap é o bico de spray que possibilita um traço mais grosso, diferente do que costuma vir nas marcas mais comuns de tinta em spray.

${ }^{73}$ Produto feito para engraxar sapato, muito usado na "Pixação paulistana" pelo fato de ter boa cobertura e já vir com seu próprio aplicador de espuma. Embora não seja necessariamente tinta ele cumpre a função de deixar a marca nas paredes, tapumes e outras superfícies urbanas.

${ }^{74}$ Trecho do texto do comunicado à imprensa da exposição Fractured Fairy Tales, da galeria Martinez, escrito pelo curador Octavio Zaya. No original em inglês: "Born in Brazil in 1982, SALMOS started painting in 1997 in the Zona Leste section of São Paulo. He considers himself a "bomber." Being poor and unemployed, he had trouble getting materials to paint or even to do "pixação," one of São Paulo's variants of graffiti (primarily black, minimal, monochromatic calligraphy composed of straight lines and sharp edges). As he puts it, "Fat Caps were a luxury. We used rollers and bucket paint acquired from construction sites. The spray paint available was used for automobiles and of very bad quality. We used Nugget liquid shoe polish instead of markers. We would find walls to paint on abandoned properties. We had no knowledge of graffiti from outside sources." From 1998 to 2004 , he painted freight trains under the ISHI tag. In 2003, he opened his own tattoo store, from which he makes his living. In 2006, he stopped painting, and, in 2014, he re-emerged as SALMOS".
} 
de uma figura "popular" que atrai a vista do observador não iniciado nas nuances do graffiti, se junta à letra em geral ilegível para o público em geral. $O$ aspecto aglomerado do throw up de letra bolha deforma as figuras, que se desmancham em outras, delimitadas pelo traço contrastante do contorno. As figuras pop de desenhos animados e histórias em quadrinhos são amarradas e deformadas pela pintura do letreiro. 


\subsubsection{O Procedimento do Flop}

Uma das pinturas praticadas pelo artista e grafiteiro Zezão é um objeto muito rico para evidenciar várias especificidades não apenas do seu trabalho, mas também para identificar características do "Graffiti internacional" como feito no Brasil. O procedimento de pintura de um flop, o nome característico dado pelo artista a esse tipo de graffiti, é o procedimento de um throw up como praticado em São Paulo. O que é específico do trabalho de Zezão se revela no objeto pintado, uma abstração; o seu caminho até a abstração, entretanto, não é o de um típico abstracionista formado no crivo da educação formal, ou na utilização das referências da pintura abstrata, pois surge da técnica da pintura de um throw up tipicamente brasileiro.

Um throw up brasileiro é feito de maneira ligeiramente diferente do praticado em Nova lorque. A tinta látex é um material correntemente usado no Brasil para a pintura e escritura mural, técnica que não é amplamente utilizada em outros países, seguidores da direção nova-iorquina, como indicado por Tristan Manco. ${ }^{75} \mathrm{O}$ uso de tinta látex nos suportes da rua não é exclusividade do graffiti, já que a pichação paulistana, em contraste com a feita no Rio de Janeiro, pode e é muitas vezes feita com tinta látex aplicada com rolos.

${ }^{75}$ MANCO, Tristan. Graffiti Brasil. Londres: Thames \& Hudson, 2005.Graffiti Brasil. Pág. 21. 


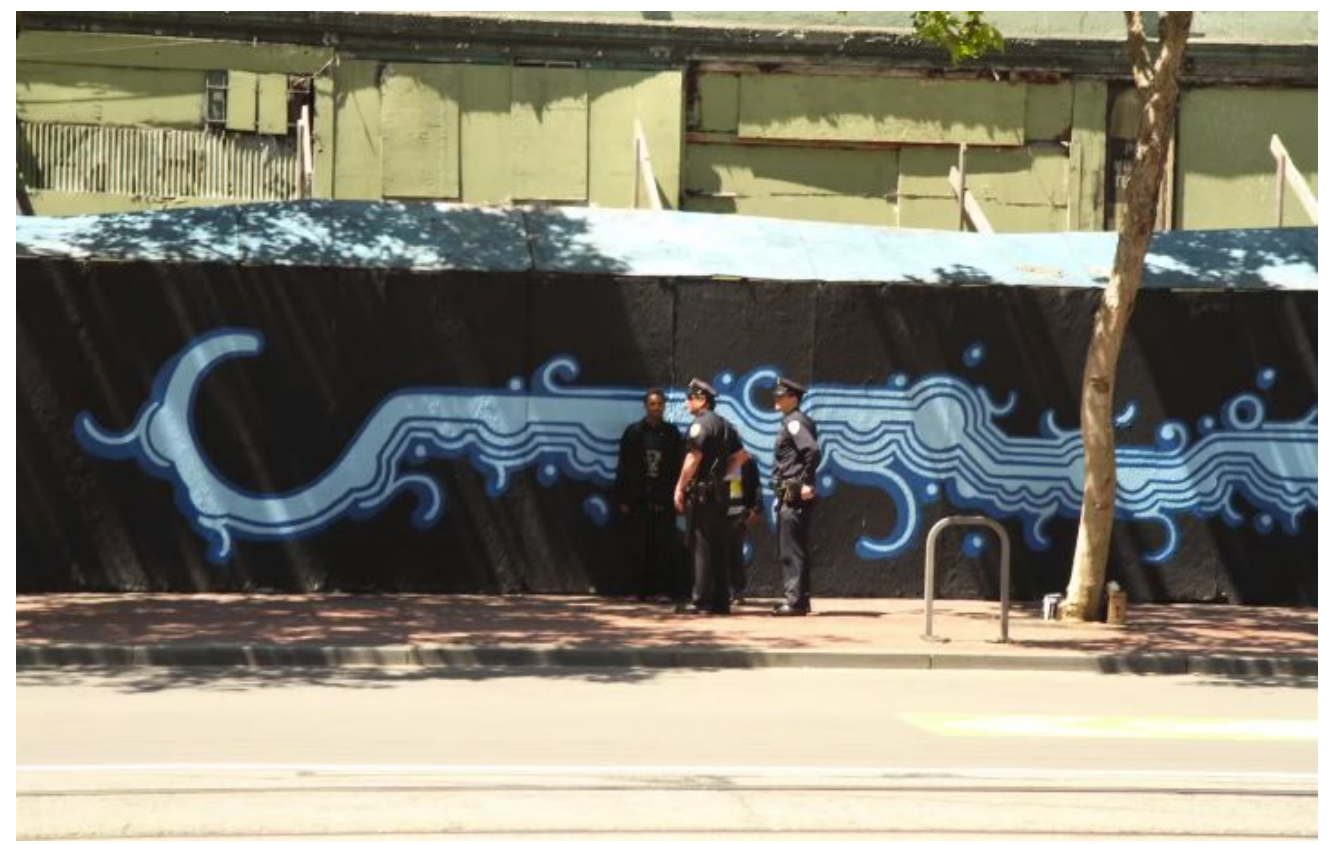

Fig. 18 - Um flop de Zezão acabado.

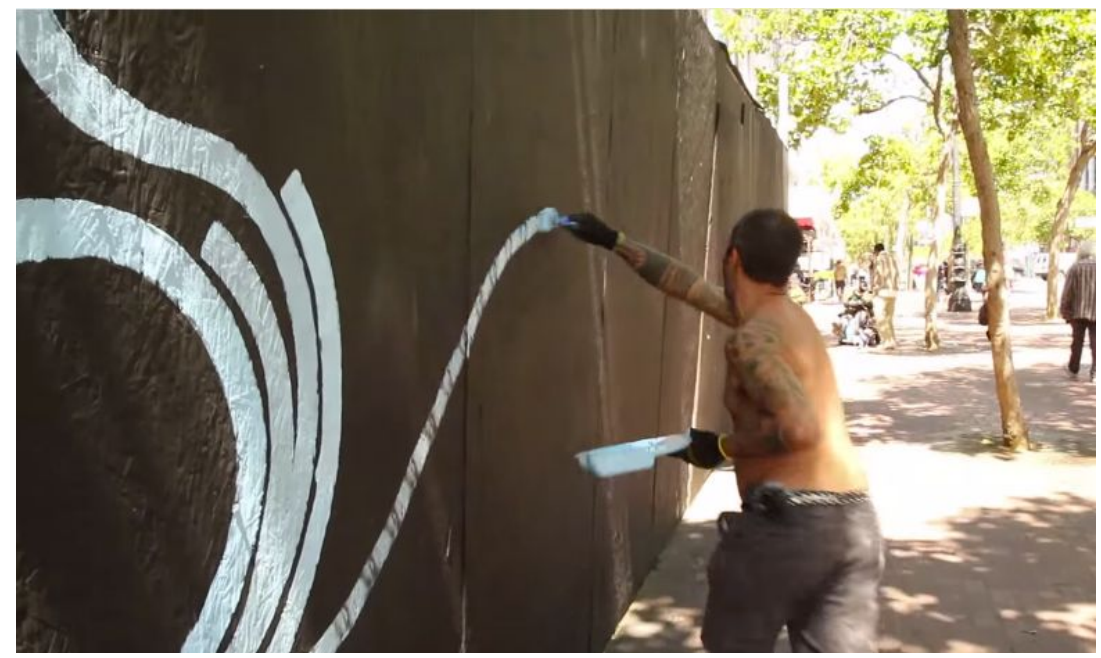

Fig 19 - Zezão usando rolinho de tinta látex para fazer o preenchimento do mesmo flop da Fig. 1

Sendo uma técnica desenvolvida para ser feita rapidamente, diferentemente das peças trabalhadas de graffiti, o throw up não começa com o que os praticantes da matriz nova-iorquina chamam de outline: um esboço feito em cor mais clara, que mostra o esquema geral da pintura antes de ser preenchida e finalizada com outras cores. O throw up como sugere o seu nome -nascido do termo que designa o ato de vomitar- é feito de uma vez, direto na parede. Para muitos grafiteiros seu throw up é 
uma extensão mais complexa e em maior dimensão do tag. Muitos dos grafiteiros, por repetirem o mesmo throw up, assim como no tag, trabalham com a repetição da mesma base, da mesma sequência corporal que traça as letras. Observando-se mais atentamente o trabalho de Salmos vê-se a repetição do mesmo traço em suas pinturas, mesmo nas quais a figura se destaca claramente do letreiro que está dentro dela. Através da repetição, seu procedimento torna-se parte da memória corporal do grafiteiro: ele sabe a sequência que o corpo vai traçar e através da repetição do procedimento, obtém consistência e rapidez. É a partir desse léxico corporal e da técnica da pintura com o rolinho que o flop de Zezão se desenvolveu.

Zezão participava de três grupos distintos: DST é uma abreviação do grupo DESTROY; VICIO era o grupo que ele participava dentro do Pixo; PIF, abreviação de Pichadores Infratores Ferroviários, era um grupo de grafiteiros que, como o nome indica, era dedicado à pintura de trens;. Ao começar a fazer throw ups com os três nomes juntos VICIOPIFDST, Zezão começou a, através da fluidez e traço suscitado pelo rolo de espuma (usado para aplicar o preenchimento do throw up), desenvolver uma pintura de letra solta, cheia de curvas e voltas. O próprio grafiteiro não sabe ao certo quando, mas suas letras ficaram tão contorcidas e difíceis de identificar, que ele abandonou por completo o objetivo de escrever algo legível, começando a aceitar o grafismo puro em seus flops.

A dificuldade de leitura de um graffiti de matriz nova-iorquina sempre foi uma barreira que separava o público geral do público estrito dos praticantes e apreciadores do graffiti. O processo de Zezão mostrou um caminho particular para o abstracionismo, vindo da pintura de letras ao invés da abstração de uma figura, ou da pintura de um não-objeto, como é o caso da abstração das vanguardas russas do início do século XX. O próprio gesto da pintura com o rolo permitiu-lhe chegar a um procedimento abstrato que pôde depois ser aperfeiçoado, até o nascimento do flop. Vale notar que não é apenas o látex do preenchimento que compõe o flop de Zezão e o throw up brasileiro em geral, mas também o contorno em spray como observado no azul mais escuro que contorna os flops. A técnica inicialmente desenvolvida a partir da falta de recursos (o látex sempre foi consideravelmente 
mais barato que o spray) se manteve enquanto procedimento comum no Brasil, até mesmo quando o spray se tornou mais acessível ao praticante. Com Zezão, houve outra prática de pintura abstrata nascida do uso do final das latas de spray, as nuvens psicodélicas. Com a lata acabando, não há mais a pressão necessária para fazer um traço firme: Zezão aproveitava seus últimos sopros para fazer leves borrifos, criando composições esfumaçadas em formatos de nuvens multicores. Quando pinta um mural em conjunto com outros grafiteiros, Zezão costuma utilizar esta técnica, mais amigável em suas transições do que a rigidez do contorno de um flop. 


\subsection{3}

NUNCA

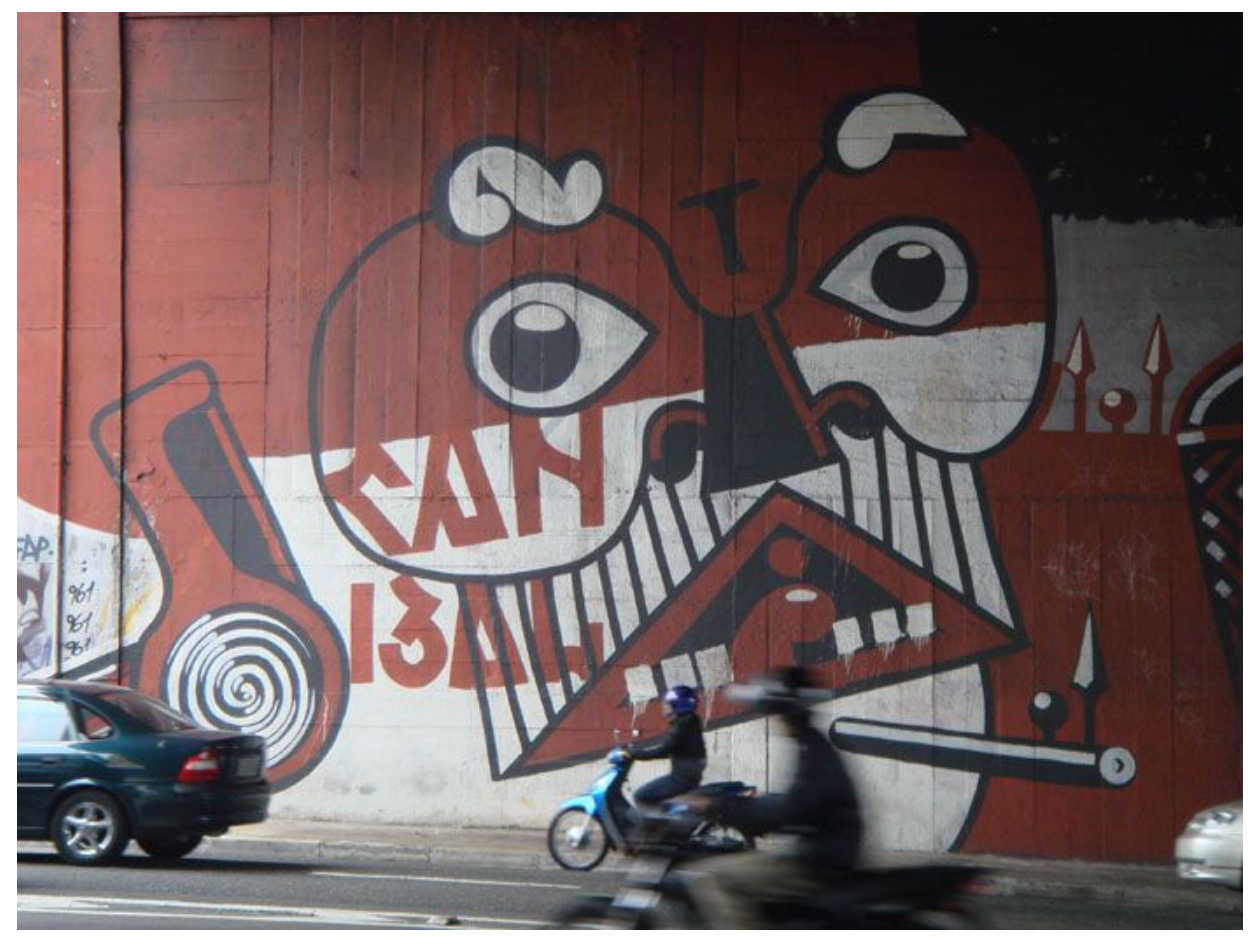

Figura 20. Graffiti de Nunca que ficava na Avenida 23 de Maio.

Tendo começado a pintar nas ruas quando o "Graffiti internacional" já estava estabelecido no Brasil e o processo de individuação de seus praticantes já estava em andamento, Nunca teve a preocupação de um trabalho autoral desde sua primeira fase de pintura mural, a não ser quando se dedicava exclusivamente à pintura de letreiros. Sua primeira fase conhecida figurava grandes cabeças feitas basicamente com tinta látex e rolo em uma paleta limitada de cores, preto, branco e vermelho terroso. As grandes cabeças muitas vezes vinham acompanhadas de letreiros feitos também em látex e rolo, ao estilo das letras do "Pixo", movimento que Nunca sempre acompanhou e estudou. 


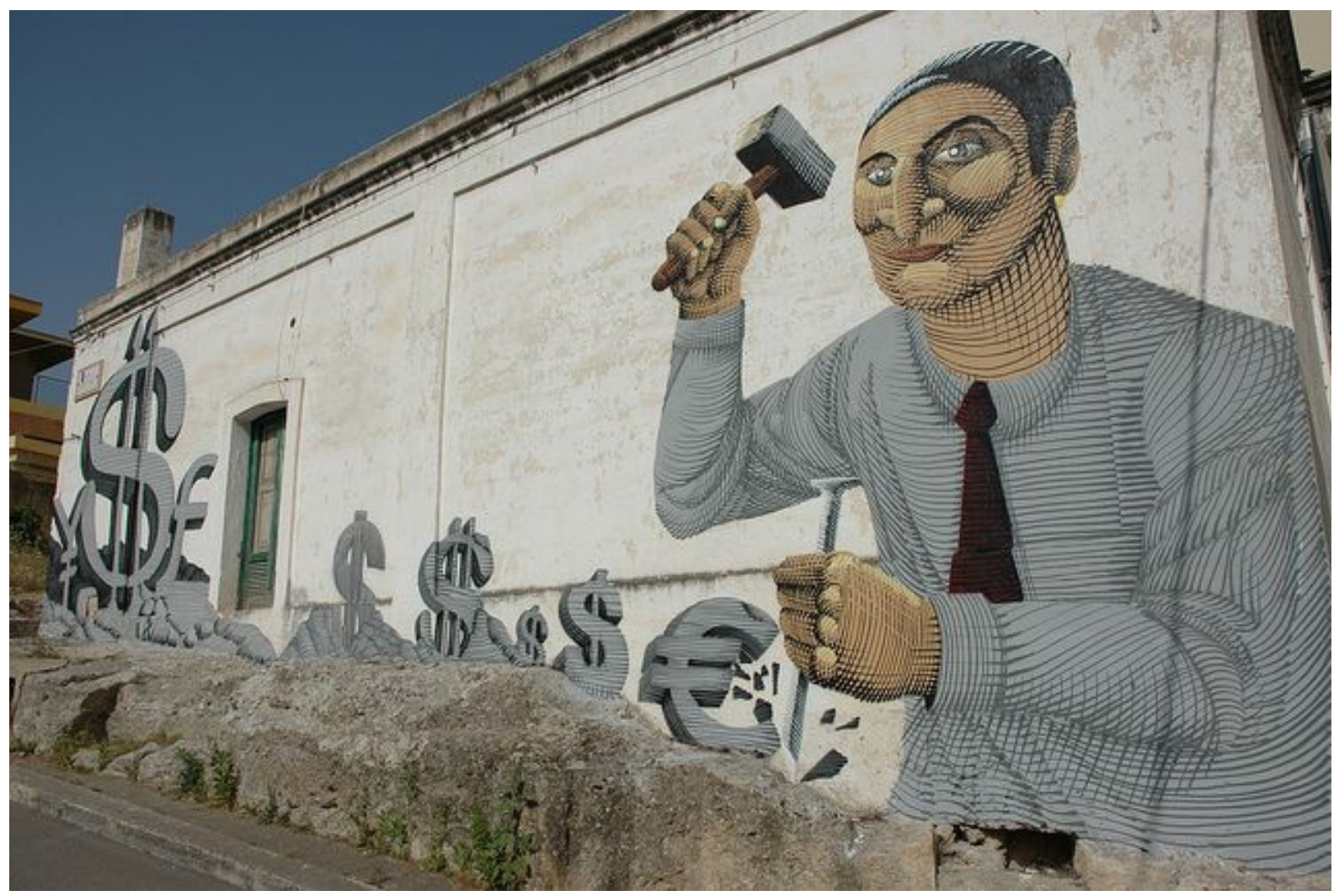

Figura 21. Mural de Nunca pintado em 2010 na Itália. Crédito: Foto do artista.

Desde esta época inicial um dos temas mais abordados por Nunca é o dos americanos nativos -mesclando símbolos do capitalismo consumista com grafismo indígena e figuras de índios canibais. Logo que se aprofundou nesta iconografia a figuração de Nunca modificou-se: indo da rigidez do traço do látex pintado com rolo para um uso deliberado do spray. As linhas que dão movimento e volume às suas figuras vieram da emulação das estrias da gravura em metal, em especial da usada na impressão das cédulas de dinheiro em papel. Assim, o tema capitalista de suas figuras incrustou-se na técnica e estilo de figuração, mostrando como a pintura mural paulistana se abriu ao uso de um número indefinido de referências em sua prática. 


\subsubsection{A xilogravura em spray}

Vindo da primeira geração de grafiteiros formados a partir do "Graffiti internacional", Speto foi um precursor dessa prática no Brasil e um dos primeiros artistas a romper com essa linhagem. A partir do interesse em fazer uma arte usando referências nacionais, Speto começou a desenvolver uma pintura mural monocromática que emula o estilo das xilogravuras nordestinas que ilustram as capas da literatura de cordel; utilizando embora a técnica do spray desenvolvida através dos anos em sua pintura de extração nova-iorquina. Em um estilo que mescla a figuração vinda da história em quadrinhos e do desenho animado, referências do "Graffiti internacional", Speto começou a desenvolver seu próprio estilo figurativo, usando essas referências em uma pintura que emula os talhos da xilogravura.

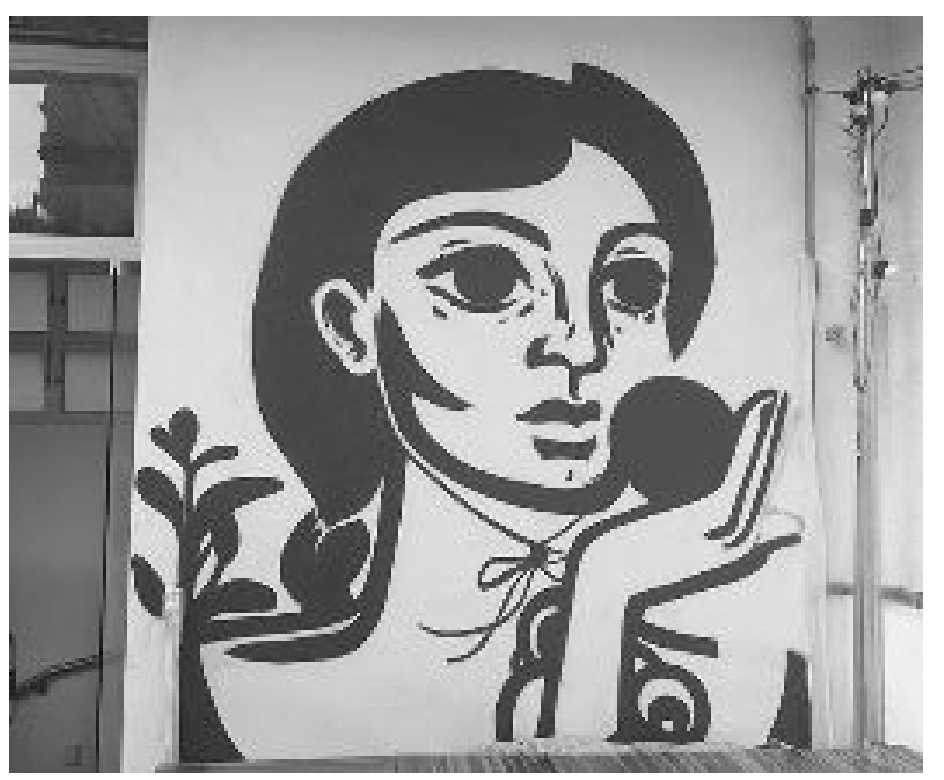

Figura 22: Mural interno pintado por Speto, sem data. Foto do artista.

A tinta em spray em duas cores permite a Speto traçar um contorno-base para a figura, repetidamente pintada em branco e recortada com uma cor escura e vice-versa, criando traços agudos no recorte da cobertura como os do talho da goiva na madeira. A técnica permite um traço inédito na pintura em Spray, que não usa as qualidades que Ihe são geralmente associadas, como a continuidade que ignora a 
irregularidade do suporte além da possibilidade das transições entre tons propiciadas pelo jato de tinta. A pintura mural de Speto desde o final da década de 1990 e começo da década de 2000 usa as cores com cada vez mais parcimônia, isso quando não as abandona como um todo para usar apenas o branco e o preto, sem degradês porém. Foi um caminho longo desde sua pintura de letreiros multicoloridos, como se vê no graffiti de 1990 que ilustra o capítulo 1.3, até as composições monocromáticas de suas pinturas mais recentes, muito mais restritas no uso de cores, de traço final e de composição. 
Possivelmente, o nome mais reconhecido do graffiti brasileiro desde o final da década de 1990, os irmãos Otávio e Gustavo Pandolfo, como Speto, são do primeiro grupo de graffiti paulistano que segue a linhagem do "Graffiti nova-iorquino". Como muitos artistas que passaram por um processo de individuação, Os Gêmeos começaram a dar atenção distinta para a figura e para o letreiro. Diferentemente de artistas como Speto, que foram abandonando a pintura de letras, Os Gêmeos continuaram a cobrir os muros com grandes letras estilizadas, sempre com uma paleta restrita pela qual ainda hoje são reconhecidos, utilizando especialmente o amarelo e o vermelho. A outra face de seu trabalho é a que os projetou internacionalmente, com a pintura de figuras humanas sempre em um tom específico de amarelo, feitas com uma técnica em spray altamente, com traços mais finos do que os que o spray com bico comum seria capaz de permitir.

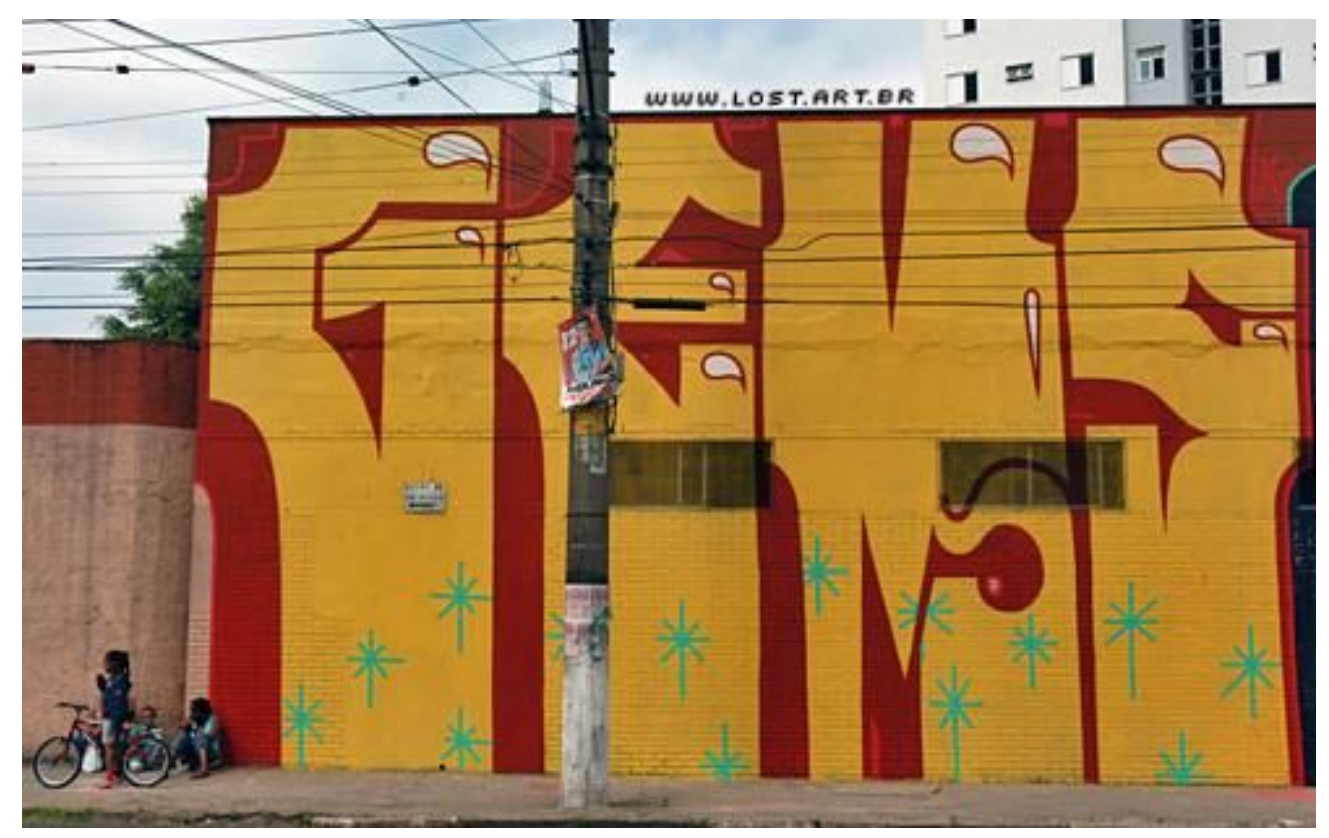

Figura 23: Graffiti de letreiro de Os Gêmeos pintado no bairro do Cambuci, São Paulo. Imagem sem data, foto de Ignácio Arovich. 
Este tratamento separado do letreiro e do personagem permitiu aos Gêmeos tornar ainda mais clara uma cisão, uma vida dupla que existe bipartindo o trabalho de rua do trabalho de atelier, notável em praticamente todos os artistas que tiveram sua formação no graffiti. Ao mesmo tempo que começaram a ser reconhecidos internacionalmente por sua pintura de figuras em murais, instalações e objetos, Os Gêmeos continuaram tendo uma carreira ativa e reconhecida de pintores de letreiros nas ruas. A separação típica entre um trabalho voltado para diferentes públicos, comum a praticamente todas as vertentes de graffiti, no trabalho de Os Gêmeos se acentua na separação do letreiro para o público do "Graffiti internacional" e o da figura para o público geral. 
O muralista Eduardo Kobra vem de uma linhagem distinta dos outros artistas tratados aqui. Hoje, um dos mais famosos pintores murais brasileiros, é reconhecido por suas imensas pinturas fotorrealistas, atravessadas por coloridos quadrantes geométricos. O que separa Kobra de outros artistas e grafiteiros aqui tratados é não vir seu trabalho do "Graffiti nova-iorquino" ou outro grupo aqui descrito, mas da pintura mural comum em São Paulo, muitas vezes chamada "Pintura comercial" e que designa a pintura feita em muros e portões de aço, geralmente em estabelecimentos comerciais, para anunciar a atividade do negócio.

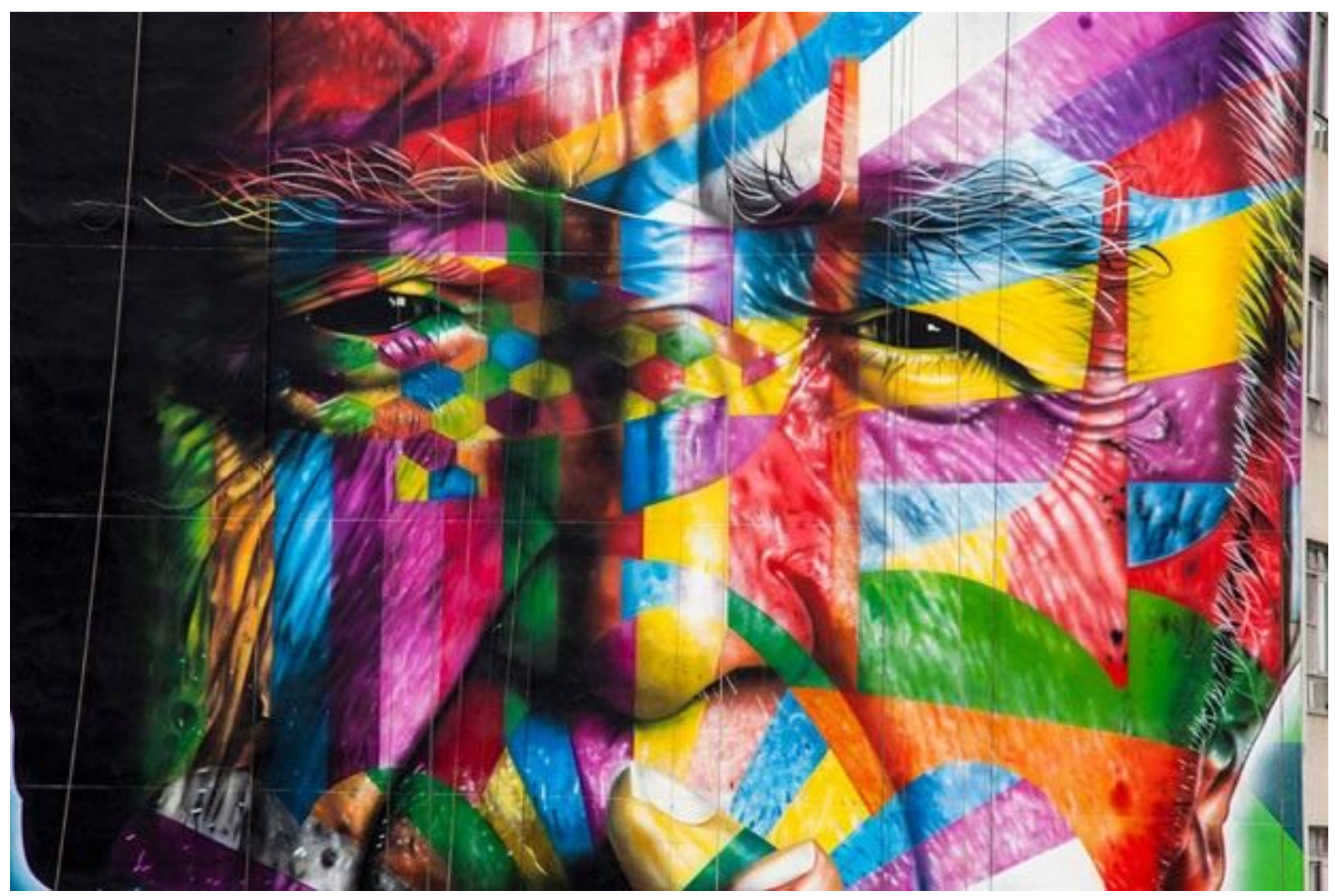

Figura 24: Detalhe do mural de Kobra na Avenida Paulista retratando Oscar Niemeyer. Crédito: Acervo do artista.

A "Pintura comercial" é feita geralmente com uma técnica que parece com o "Graffiti internacional", mas é pintada com a técnica do aerógrafo (também conhecida como pintura de compressor), que utiliza pistolas de ar comprimido mecanicamente. O aerógrafo, por ter o ar como vetor para levar a tinta ao suporte, 
tem semelhança com a pintura em spray, possibilitando a pintura de suportes irregulares e permitindo a mesma mescla de cores em gradientes, porém tem a vantagem de poder usar diferentes tipos de tinta, carregados na pistola. Outra vantagem técnica que o aerógrafo tem em relação ao spray é ter ele diferentes pistolas com calibres também diferentes, utilizadas na alternação da largura do traço final. A tinta em spray tradicionalmente trabalha com três tipos de bicos, do mais largo para o mais fino: fat cap, banana cap e skinny cap. A principal vantagem do spray sobre o aerógrafo é a mobilidade, já que o segundo depende de uma fonte de energia ligada a um pesado e barulhento compressor, impossibilitando o seu uso em uma pintura ilegal, à noite e às escondidas.

Os murais de Kobra seguem um procedimento extremamente facilitado pela pintura com aerógrafo. O primeiro passo é a pintura de um esboço usando uma referência fotográfica. A partir desse esboço é feita uma pintura em grisalha ${ }^{76}$, a partir desta pintura, já com volume, são traçados os quadrantes que vão ser preenchidos de fortes tons de cores vivas pintadas com uma tinta transparente para que os tons de cinza da grisalha por baixo transpareçam. A partir disso, a pintura é retocada e ajustada de acordo com a referência fotográfica. Este complicado procedimento não é prático para a pintura do graffiti ilegal, tanto pelo uso do compressor quanto pelas diversas camadas de procedimento necessárias para chegar ao mural final. Curiosamente, Eduardo Kobra, um dos mais reconhecidos artistas murais brasileiros, passou ao largo da linhagem de pintura mural que a princípio tornou o Brasil reconhecido no resto do mundo.

${ }^{76}$ Nome dado a uma pintura feita inteiramente em apenas um tom, geralmente nuances de cinza. 


\section{Conclusão}

Os grupos descritos na primeira seção, a Pichação poética, o Graffiti dos anos 70, o Graffiti internacional e o Pixo, não esgotam toda a produção mural da cidade de São Paulo. Como visto na descrição do trabalho de Kobra, por exemplo, existem outras tradições paralelas às práticas que começaram e se estabeleceram entre a década de 1970 e começo de 1990, como as de figuras periféricas a essas práticas: Carlos Adão, Neguinho ZO, Carioca ZL. Além da continuidade da pichação de caráter político que nunca deixou de marcar as paredes das grandes cidades (grande catalisador para esse tipo de pichação foram as manifestações políticas que ocorreram em São Paulo e outras cidades do Brasil na última década). Apesar da conceituação do processo de individuação, é importante lembrar que o "Graffiti internacional" continua sendo feito em São Paulo, e ainda existe uma vigorante cena de pintores de letreiros, que mesmo não parecendo romper com a linhagem americana, continuam inovando em seu nicho.

Embora a produção mural paulistana aqui descrita não tenha critérios de demarcação tão exatos, a produção posterior -dos anos 2000 para frente- será ainda mais difícil de ser classificada em grupos bem definidos: o processo de individuação muito fez por acentuar o afastamento de uma definição clara de como - graffiti seria visto no Brasil. A década de 2000 também viu uma imensa popularização da internet e, com ela, o aumento da possibilidade de comunicação e acesso a referências outrora de difícil acesso. Também será a partir dessa década que o termo "Arte urbana" começa a se popularizar no Brasil e, com ele, novas possibilidades de materiais, técnicas e procedimentos começam a aparecer nos muros da cidade: lambe-lambe, sticker, graffiti e pixação feitos com extintor, intervenções. Grupos especializados nessas novas técnicas, como o SHN, popularizaram o uso de lambe-lambe e sticker feitos em um estúdio em serigrafia, para depois serem usados para marcar a cidade, com ligação a um movimento internacional de "Arte urbana", como visto no trabalho do americano OBEY (Shepard Fairey) e movimentos análogos na Europa e Argentina, por exemplo. 
O processo de individuação de muitos grafiteiros formados inicialmente no "Graffiti internacional" permite uma projeção desses artistas no mercado tradicional de artes. A partir de suas referências e pesquisa nas ruas, muitos deles começam a trabalhar com suportes tradicionais, como pintura em tela, gravura e escultura. A inserção do graffiti no mundo tradicional das artes não é novidade: em 1985 Alex Vallauri, Carlos Matuck e Waldemar Zeidler participam da $18^{a}$ Bienal de Artes de São Paulo, e muitos dos praticantes da primeira onda de graffiti paulistano do final de 1970 e começo de 1980 desenvolvem desde então um corpo próprio de trabalho em artes visuais. Porém, diferentemente da linhagem vinda de Nova-lorque, eles não tinham um corpo de regras visuais e de procedimento definido com o qual romper. Hoje, é corrente um artista vindo do "Graffiti internacional" ser representado por uma galeria de arte que expõe artistas formados pela educação em artes. A eterna discussão sobre graffiti ser ou não arte foi cuidadosamente ignorada durante esta pesquisa, especialmente na tentativa de evitar uma identificação valorativa entre "arte" e "não-arte", semelhante à valoração corrente de "graffiti" e "pichação" que, embora identificados enquanto práticas distintas nos capítulos anteriores, é basicamente uma separação matricial e prática.

Tentou-se, aqui, identificar as práticas de acordo com suas definições próprias e como elas mesmas se apresentam, e não uma classificação por demais teórica que tente identificar generalidades a partir de que se encaixem em grupos. Pesquisas posteriores podem tentar testar com mais proximidade as práticas aqui descritas, além de proporcionar pontos de identificação no trabalho dos praticantes com suas matrizes, propiciando a possibilidade de uma crítica de seus trabalhos que não pressuponha as histórias da arte tradicionais, mas que busque as referências dentro das tradições com as quais muitos desses artistas romperam, enriquecendo as descrições e os conhecimentos de seus trabalhos. 


\section{BIBLIOGRAFIA:}

CHALFANT, Henry; COOPER, Martha. Subway Art. Londres, Thames \& Hudson, 1984.

CHALFANT, Henry; PRIGOFF, James. Spraycan Art. Londres, Thames \& Hudson, 1987.

CHASTANET, François. Cholo Writing: Latino Gang Graffiti in Los Angeles. Dokument Press, 2009.

CHASTANET, François. Pixação: São Paulo Signature. Paris: XGpress, 2007.

DANYSZ, Magda. From Style Writing to Art: A Street Art Anthology. Roma, Drago, 2010.

FONSECA, Cristina. A Poesia do Acaso (na transversal da cidade). T. A. Queiroz, editor, São Paulo, 1985.

GITAHY, Celso. O que é Graffiti. São Paulo: Brasiliense, 1999, $3^{\text {a }}$ reimpressão 2012.

LASSALA, Gustavo. Pixação não é Pichação. São Paulo: Altamira Editorial, 2010.

LEWISOHN, Cedar. Street Art: The Graffiti Revolution. Londres, Tate Publishing, 2008.

MANCO, Tristan. Graffiti Brasil. Londres: Thames \& Hudson, 2005.

MARCELO, João. Xarpi: Um Registro Sobre a Pixação no Rio de Janeiro. Rio de Janeiro, Edição do Autor, 2015.

MATUCK, Carlos; KOSSOVITCH, Leon; ZAIDLER, Waldemar. Nox: São Paulo Graffiti. São Paulo: Cinemateca Brasileira, 2013.

McDONALD, Nancy. The Graffiti Subculture: Youth Masculinity and Identity in London and New York. Nova lorque, Palgrave Macmillan, 2001.

MEDEIROS, Daniel (org.). Ttsss... A grande arte da pixação em São Paulo Brasil. São Paulo, Editora do Bispo.

SPINELLI, João J.Alex Vallauri Graffiti. São Paulo: Bei, 2010.

New Haven, Yale University Press, 1985.

STEWART, Jack. Graffiti Kings: New York City Mass Transit Art of the 1970s. Nova lorque, Abrams, 2009.

SZACHER, Allan (org.). Estética Marginal Volume 2. São Paulo, Zupi Editora, 2012. 


\section{Anexos:}

\section{Entrevistas}

\section{Entrevista 1:}

Entrevista por e-mail com Alex Antunes após uma conversa presencial. Perguntas respondidas em 1 de agosto de 2017:

Pedro Moreira Graça: Quem eram o "Rendam-se terráqueos"?

Alex Antunes: Celso "Minho K" Pucci, Renato Cosentino, Paulo Zocchi e eu. Éramos quatro, a lotação total de nosso único carro, uma belina do pai do zocchi. basicamente o zocchi era o motorista e nós outros três nos alternávamos na vigilância e na pichação. Nunca fomos pegos. nossa área de intervenção mais frequente era entre as imediações do aeroporto de congonhas, onde morávamos três de nós, e as imediações da usp, onde estudávamos e morava o quarto. Que eu saiba, as imediações da usp eram então o mais frequente local de pichações da cidade

$P:$ Que idade vocês tinham mais ou menos na época que começaram as ações? A:19 anos, nós os quatro, acho

P: Você me disse na nossa conversa que as primeiras pichações que vocês viram nas ruas, que levaram vocês à pichação, foram o "Cão Fila" e o "Celacanto Provoca Maremoto", você pode me falar um pouco de como foi o impacto de ver essas pichações na rua?

A: Elas gravam um burburinho, de que eram pichações contra a ditadura. Não sabíamos quem as fazia; pareciam códigos secretos, quer dizer, a gente sabia que o celacanto era citação do National Kid. então eram códigos antiditatoriais pop. Na nossa conversa, tive uma certa clareza de que estávamos começando a moldar, em primeiríssima mão, uma energia que a partir de 1983 se mostrou inteira e exuberante no underground de são paulo.

P: Estou usando na minha pesquisa o termo "Pichações Poéticas" para se referir ao grupo expandido de pichadores como vocês que faziam ações nas ruas que, apesar de poderem ter elementos visuais, como era o caso de vocês, era mais focado em uma frase enigmática ou assinatura. Você acha que o termo "Pichações Poéticas faz sentido? Ainda sobre o 
termo "Pichações Poéticas", a parte da poesia se refere a alguma ligação com algum movimento de poesia ou literatura à época? Se fizer sentido falar em "Poesia", que sentido teria esse termo?

A: Num sentido amplo de 'poético', faz. Não porque fôssemos leitores de poesia. Creio que nós quatro, apesar de dois de nós arriscarmos uns versinhos, achávamos poesia um treco em geral bastante pedante. Éramos mais chegados em letras de música. por exemplo, não faria sentido puxar uma relação com a poesia neoconcretista (cito isso porque você disse que há quem o faça). Mas o poético entra aí no sentido da poética contracultural, do slogan desconstrutivo, disparador de insights. acho que isso estava sincronizado com a nossa apropriação dos muros, que em si mesma era um tipo de ruído, de provocação não-programática, de 'ocupação psíquica'.

P: Que outras pichações você lembra da época que você acha que eram análogas às de vocês?

A: te amei hoje uso agenda

hendrix mandrake mandrix

gonha mó breu

mas, er, groam

maria clara, quero a gema

vejo um vulto na janela (essa seria inspirada em uma peça de 1979 - ou feita pelo próprio pessoal da peça)

O 'juneca pessoinha' apurei que foi um dos primeiros periféricos, né? Uma amiga minha mencionou 'oi mmoi, bilim pra cá, bilim pra lá', mas essa eu mesmo não vi. A Ana Maria Baianha lembra que no rio tinha a 'tatu do mundo louco'. Acho que o 'lerfá mú' era do rio também.

FIM DA ENTREVISTA 


\section{Entrevista 2:}

Entrevista com Carlos Matuck, gravada no dia 24 de outubro de 2014.

Pedro Moreira Graça: Então, quando você começou a mexer com carimbo?

Carlos Matuck: Porque eu comecei a mexer com carimbo eu não faço a mínima ideia, preciso lembrar.

P: Ah não, eu perguntei quando.

C: Quando? Ah, quando eu lembro. Foi em 78 ou 77, mais ou menos por essa época. Gozado, não consigo lembrar, como eu comecei a mexer com carimbo e porque que eu comecei a gostar. Eu tenho essa noção, que em $99 \%$ dos casos é verdade, de ter descobreto as coisas através do Rubens [Matuck, seu irmão], então pode ter sido. Na maior parte das vezes é verdade de coisas dessa época, eu sou bem mais novo que ele, temos seis anos e meio de diferença.

$\mathrm{P}:$ Em 78 você tinha quantos anos mais ou menos?

C: Vinte.

$P$ : Já estava na faculdade.

C: Entrei em 79.

$\mathrm{P}: \mathrm{Na} F A U$, foi lá que você conheceu meu pai?

C: Não seu pai eu já conhecia. Conheci ele quando ele começou a namorar a Mariana. Nós entramos mais ou menos na mesma época, nós somos todos da mesma idade. Me lembro de ter conhecido ele antes de entrar na FAU. Então, talvez tenha sido de uma maneira que aconteceu muito comigo aqui em São Paulo. Eu sempre gostei, e isso também de certa maneira também era o Rubens que me proporcionava, ele começou a trabalhar muito cedo, ainda morando com meus pais, trabalhava no jornal e já ganhava uma grana. E aí ele me dava um dinheiro, de bobeira, quando ele recebia ele me dava uma grana, era uma libertação pra mim porque lá em casa éramos quatro. Não tinha mesada, não ganhava nada, vivia sem grana, ele me dava essa grana e eu saia pela cidade, ou ia à Augusta, onde tinha umas lojas de aeromodelismo ou ia na aerobrás, ou, depois eu comecei a andar, talvez aí eu já trabalhasse. Eu comecei a dar aula em 78 eu já era professor de artes, já ganhava um dinheiro e ainda morava com meus pais, aí que eu comecei a alugar atelier. $\mathrm{E}$ 
eu sempre gostei de andar pelo centro, e ir descobrindo lugares. E uma das coisas que eu ficava olhando com fascinação eram essas lojas de carimbos, naquela loja ainda existiam muito mais do que hoje. Tinha alguns que eram mais diversificados que faziam placa de metal, era muito legal. E em algumas delas tinha alfabeto de carimbo, e umas caixas antigas de escola, aquela mais típica, com os galos, os patos, as vacas, essem foram os primeiros que eu usei nos trabalhos, esses infantis. Depois eu comprei uma caixa de cem, que eu usava quando eu era criança que tem as imagens das palavras usadas pelas professoras naquela época usadas para a alfabetização.
P: Como o que?
C: Pião, vulcão...

\section{P: Abelha?}

C: Bichos? Não sei se tinha bichos. Era uma caixa imensa, não consegui guardar aquela caixa, eram cem carimbos pequenos, super legais os desenhos, bem dos anos cinquenta. Tinha um monte de coisa, estou esquecido porque tenho que mexer nas coisas no atelier. $E$ isso eu comecei a usar no trabalho. Foram três coisas que aconteceram mais ou menos ao mesmo tempo na minha cabeça, esses passeios e a descoberta dos carimbos escolares, conhecer o Vallauri. Eu já conhecia mas eu não conhecia o trabalho dele, eu conhecia ele, porque ele era amigo do Arthur e do Rubens [irmãos de carlos], então eu já encontrava ele por acaso em vários lugares, já nos falávamos. Quando ele começou a fazer graffiti eu já sabia que ele fazia graffiti. Quando eu fiquei amigo dele, quando começamos a conversar mais e falar de carimbos, eu descobri que ele tinha uma coleção de carimbos, e conhecia um lugar fantástico chamado Carimbos Dulcemira.

P: Já ouvi falar.

C: O lugar era inacreditável, esse lugar eu me arrependo até hoje de não ter ido lá, o cara me ligou, nós éramos frequentadores...

P: Era uma fábrica de carimbos?

C: Era uma fábrica de carimbos de borracha, era assim que chamava, mas não eram carimbos para carimbar, era impressão em anilina. Você pode saber de um tipo dessa impressão, rudimentar, meio vagabunda, muitíssimo usada, talvez você vá reconhecer se eu te falar... 


\section{P: Saco de pão?}

C: Saco de pão, papel de embrulho. Essas duas coisas, principalmente papel de embrulho, aqueles rolos, eles imprimiam aquilo com as matrizes de borracha, chamava impressão em anilina porque a tinta é líquida, parece tinta de carimbo. Então essas coisa de ser embrulho é que era legal, eles começaram nos anos cinquenta, talvez quarenta, não tenho certeza. Tinha loja de chapéu, loja de tecido, radio e TV, loja de umbanda, peça de carro, então tinha tudo quanto era carro, o catálogo é fantástico, o catálogo é um monumento de uma época. Eu tenho dois, eu guardei o catálogo.

P: Você tem digitalizado isso?
C: Não.

P: É importante isso hein? Para guardar.

C: Eu tenho o físico, e comprei o máximo de carimbos que eu pude, eu tenho cento e poucos, mas eu devia ter comprado o catálogo inteiro. Quando eles foram fechar, por termos ido tanto lá, e eles sabendo que éramos artistas, aí o cara me ligou e disse "Olha, nós vamos fechar, você não quer vir dar uma olhada, ver se não quer alguma coisa ainda? Porque vai fechar a fábrica". Puta, eu era tão duro bicho, hoje eu teria feito um empréstimo bancário, qualquer coisa. Eu comprei uma porrada que eu gostava, mas ainda olho o catálogo hoje e falo "puta, eu não tenho esse, que merda".

$\mathrm{P}$ : Mas o que aconteceu com os carimbos, mais ninguém comprou?

C: Olha, o Vallauri tinha uma quantidade absurda de carimbos da Dulcemira, mais do que eu. E a coleção dele, a mãe dele não era a pessoa mais preparada para cuidar disso ou para dar para alguém que cuidasse. Acho que ela deu para as crianças da empregada. $\mathrm{A}$ única outra coleção de carimbos da Dulcemira que eu conhecia era a dele. Tinha duas no mundo a minha e a do Vallauri eu acho. Agora só tem uma. O Júlio tem um pouco porque a mãe de Vallauri deu pra ele.

P: Que júlio?

C: O Júlio Barreto, ele tem uma história ótima que interessa para sua pesquisa que é a seguinte. A família do Vallauri mudou para uma casa do lado da casa dele ele era vizinho de muro do Vallauri. E quanto o Vallauri começou a fazer graffiti ele tinha doze anos, e começou a ajudar o Vallauri. O atelier do Vallauri era numa garagem que dava pra calçada no Alto da Lapa, então o Júlio passava de bicicleta ou brincando na rua, e a porta tava 
aberta com o Vallauri trabalhando, ele tinha uma prensa, ele trabalhava com impressão de tecido. E ele entrava pra ver o que tava acontecendo, e o Vallauri ia explicando as coisas pra ele. Então ele é um artista que é artista por causa do Vallauri. Ele é filho de intelectuais, a mãe dele era professora da USP o pai dele era psiquiatra, mas a verdade é que quem levou ele pro mal caminho foi o Vallauri.

P: Você disse que tinham acontecido três coisas mais ou menos nessa época...

C: Então, eu passei a andar pela cidade, que sempre fui fascinado em conhecer o centro, em visitar o centro e ver o que tinha ainda. Nos anos setenta ainda tinha umas coisas que puta, hoje eu vou lá e fico tristíssimo. Filatélica, selo é uma viagem. Eu adoro, não consigo colecionar porque dá um trabalho infernal. Eu tenho milhares, porque o meu pai tinha muito, me deu tudo e ficou comigo.

P: Quem tem uma relação legal com selos é a Mariana [Martins] mas ela usa.

C: Eu usei muito também! Nessa época, setenta e oito setenta e nove, aliás eu ainda uso até hoje na verdade. Aqui ó [mostra trabalho] aquilo é baseado em um selo egípcio. A gráfica de selo é fascinante, se você gosta de artes gráficas você não pode escapar do selo. É uma peculiaridade histórica das artes gráficas, tem um mais maravilhoso que o outro. Então eu ficava louco nas filatélicas. Eu ia comprar selo, e nessa você descobre selo; tinham essas filatélicas com importação de selo ainda, muito legais; sebo, claro, tinha uns sebos fantásticos nessa época, o (???) ainda estava aberto, em plena praça da Sé, com aquele senhor de terno e colete indo lá todo dia, num calor de trinta e cinco graus era um velhinho que usava colete e paletó, todo dia. Tinha um outro que era gigantesco, tinha um nome muito estranho, chamava assim, Ornabí. Era Organização Nacional de Bibliotecas, esse se não me engano ficava na José Bonifácio, centrão. Eu vivia no centro, naquele buraco do centro antigo de São Paulo, atrás disso. Livro, bibliografia, livro de imagem, carimbo, selo, papelarias, ainda tinham papelarias antigas que você conseguia comprar aqueles livros notários, aqueles livros de anotação, alguns em branco. Caderninho antigo, tinha umas papelarias com estoque antiquíssimo ainda, dos anos cinquenta, São Paulo tinha essas coisas, está acabando. Tem uma ou outra coisa ainda mas por exemplo, papelaria não tem mais, papelaria virou tudo Kalunga. Eu não conheço mais. Mas o que eu conheci de sebo, puta. Então, era isso aí, esses passeios, o Vallauri e está faltando um, acho que falei três por causa dos estênceis. Aí foi a coisa do graffiti, aconteceu ao mesmo tempo, e pra mim muito relacionados os caminhos. 
P: Eu vejo uma relação direta do estêncil com o carimbo.

C: Pra mim tem uma relação direta, pra mim eles faziam a mesma coisa mas em diferentes suportes, que é a reprodução. E na minha história de vida foi muito junto, então nos trabalhos que eu fiz de carimbo nessa época eu usava estênceis de maneira rudimentar mas usava. Na verdade eu usava mascaramento, separava a área carimbava só dessa área para cá, construía, também trabalhei com colagem, a coisa do corte sempre esteve presente. Cortar coisas com estilete eu sempre gostei, é uma característica estranha que eu não sei da onde veio, cortar e colar, cortar e colar, colagem é uma constante do meu trabalho desde jovem, então o estêncil caiu como uma luva, juntou essas duas coisas, cortar coisas, carimbar e uma terceira que era importante para mim nessa época que era fazer alguma coisa que o Rubens não fazia. Certa maneira foi impossível não virar um Rubinho, noventa porcento das coisas que eu aprendi, o que eu sei de gravura o que eu sei de pintura, o que eu sei de papel, quase tudo comecei vendo com o Rubens, óbvio, ele tinha já um atelier.

$\mathrm{P}$ : E tem aquela coisa do jovem de querer fazer a coisa dele.

C: Eu queria fazer uma coisa né, diferente talvez, não foi consciente, você não faz essas coisas conscientemente. Conheci o Vallauri, era uma outra pessoa, não era o Rubens, já é uma atração, uma coisa diferente. A gente começou a conviver e a gente começou a fazer graffiti.

P: E como foi esse começo do graffiti? O Vallauri já fazia?

C: O Vallauri já fazia a botinha, a luvinha, tudo separado. Ele carimbava né? Era umas coisas como os carimbos Dulcemira, como história em quadrinhos, a panterinha da selva, o acrobatinha que ele tirou do Seurat. Então a gente começou a fazer sessão de carimbo, ficávamos lá o dia inteiro vendo os carimbos, carimbando, compondo, vendo qual era legal com o outro.

$\mathrm{P}$ : E foi um processo natural ir para o muro? Carimbar o muro?

C: Total, pra mim foi total. Os primeiros graffitis que eu fiz ou eram de quadrinhos que eu gosto muito de quadrinhos ou eram de carimbo. Aí começamos a juntar e isso que foi legal, a gente começou a montar coisas, e era sempre uma relação de ressonância, ele fazia uma coisa e eu fazia uma parecida e no final a gente acabava montando. Ele fez aquela guitarra, que era da Dulcemira.. 


\section{P: Era da Dulcemira?}

C: Era, muita coisa era da Dulcemira, o frango assado era da Dulcemira, as pinups eram da Dulcemira, as estampas eram da Dulcemira. No carimbos Dulcemira, como os mercados não eram essa coisa maluca de redes enormes, existia um aqui e alí. Existia um aqui um ali, a Dulcemira tinha papel para esses supermercados também. Tem umas imagens do carimbo dulcemira que são mulheres no supermercado, com carrinho e tudo, e elas são com a saia estampada de folhas, entende? E tem tudo a ver com as mulheres que ele fazia, os carimbos Dulcemira são um universo no trabalho do Vallauri. As pessoas não sabem isso. E quando sabem não dão a importância que tem, porque não conviveram com ele.

P: Eu li aquele livro recente, do Spinelli. E tive muita coisa de informação lá que eu não sabia sobre o Vallauri, mas o jeito que ele fala sobre como o Vallauri começou a fazer Graffiti parece que é uma coisa muito mais intelectualizada, sobre o processo da gravura que depois ele foi desenvolvendo pra isso. Tudo bem tem a ver gravura com carimbo, mas para mim visualmente e com você contando isso tudo, eu vejo de cara que esse negócio é um carimbo que você usa para fazer as composições. Não passa por um processo intelectual.

C: Ah não, ele não era uma pessoa intelectualizada.

$P:$ É que tem essa visão muitas vezes que o artista tem que ser esse cara, cerebral.

C: É que hoje em dia, diferente daquela época, dos anos setenta, não existe mais artista que não é formado na universidade. Isso é uma tragédia, na minha opinião é uma tragédia. Tirou toda a liberdade da coisa, podemos falar isso já que estamos falando da academia, vivemos um novo academicismo, todo mundo pensa do mesmo jeito. Eu acho que isso tudo foi prática, obviamente que a prática da xilogravura e da impressão xilográfica teve a ver com os graffitis, lógico, no caso do Vallauri, claro, a mesma coisa os carimbos, mas eu estou falando de imaginário.

\section{P: Onde estávamos?}

C: Estávamos nesse começo, aí virou aquela adrenalina, ele fez aquela guitarra e eu tinha acabado de trazer dos estados unidos um carimbinho de sanfona e aí eu fiz uma sanfonona na escala da guitarra. 


\section{P: Aí que veio a banda.}

C: Daí a gente foi pro atelier e pensou, só dois? A gente fez só dois um cara tocando uma sanfona e um cara tocando uma guitarra, tem até um maravilhoso que a gente fez aqui na Mourato Coelho que são dois caras tocando. Esse começo eu fazia uns estênceis mas o Vallauri já tinha muito mais prática de fazer o traço [com spray] à mão livre do que eu. Era basicamente ele que fazia, eu não ensaiava isso, eu ia ajudando, fazendo o meu stencil. Eu já tinha feito uns chapéus, um do Santos Dummont outro do Dick Tracy então a gente fazia ele tocando com esses chapéus, era uma coisa deliciosa de fazer, prazer puro em fazer, não tinha nada intelectual. Zero, o que tinha de intelectual estava tudo antes. No ato do fazer aquilo era prazer puro, prazer total, não tinha nada, não tinha picas, era só o prazer de fazer, o tesão. Aí a gente fez um trompete juntos, também do Dulcemira, ou de um carimbo americano agora eu não lembro, mas fizemos juntos lá no meu atelier, mas eu lembro a gente fazia isso, desenhava juntos. la desenhando, tal, cortava, então a gente fez um trio. E o Vallauri deu aquele nome maravilhoso O Trio Los Panteras, que tudo ele botava aquelas panteras dele. E ele colocava as pinupinhas cantando junto e virou o Trio Los Panteras y Las três Panteretas.

$\mathrm{P}$ : Como você intelectualiza isso?

C: Nada, aquilo vinha também de tesão pela música cubana, ele só ouvia Célia Cruz e salsa. Ele tinha uma história engraçada com música, eu não cansava, eu adorava as músicas que ele ouvia, mas as vezes as outras pessoas ficavam incomodadas, mas ele não era radical se falasse para colocar outra música ele topava ouvia João Gilberto.

P: E o Zaidler, o gordo, vocês começaram a pintar juntos nessa mesma época?

C: O Gordo é meu amigo desde os onze anos. Conheci ele no Santa Cruz com onze anos de idade, na primeira série, no que era o ginásio na época o que é hoje a quinta série. Alguma série. A gente tinha onze anos, ele frequentava também o atelier do Rubens comigo quando a gente era adolescente, a gente ia lá direto. E ele entrou na FAU, um ano antes do que eu. Muitas vezes ele saía da FAU e passava no meu atelier, que era caminho pra ele, e ele começou a trabalhar também, começou a fazer estêncil, começou a acompanhar a gente, começamos a pintar junto.

$P: E$ o que tinha na rua essa época? Tinha alguma coisa? 
C: Tinha bastante coisa na rua, tinha um povo que fazia bastante coisa, graffiti né? Um que era legal que misturava palavra e imagem era o Edficil, que era ótimo, se não me engano era do Tadeu Jungle, ou do Fernando Meirelles, essa gente pichava. E você vê que a gente usa o termo correto usado naquela época.

\section{P: Qual?}

C: Pichar, ninguém falava vou fazer graffiti. Vamos pichar, a frase famosa do Vallauri era essa "Vamos pichar?" tanto que eu me recuso a essa divisão, eu não concordo.

$\mathrm{P}$ : Eu concordo, mas posterior.

C: Só se for.

P: Porque pra mim tem uma coisa muito séria, como eu comecei a minha pesquisa? Eu comecei a enxergar pelo menos duas gerações iniciais do que eu chamo de graffiti paulistano, que é a galera como vocês e o Rui Amaral, o Tupinãodá, tinha toda uma turma.

C: É, que vieram um pouco depois.

$\mathrm{P}$ : Sim, eles vieram um pouco depois de vocês. Aí veio da américa o graffiti nova-iorquino.

C: Sim, o Hip Hop né?

P: Através do Hip Hop vem o graffiti nova-iorquino.

C: Forte, a gente acompanhava um bocado do graffiti nova-iorquino também, bom, o Vallauri foi pra lá.

P: Sim, no livro do Spinelli tem correspondência dele falando sobre.

C: Ah, sim eu tenho também correspondência dele falando.

P: Isso me interessa.

C: Eu tenho uma coisa que na época era um fascínio pra gente, que ele fazia graffiti com as nossas máscaras, com as deles e com as nossas, então tá cheio da minha sanfona pintada em Nova lorque porque eu me lembro bem, ele falava "Vou pra Nova lorque, vamos copiar as máscaras." porque era como os carimbos, a cabeça era como os carimbos, como carimbo a gente fazia muito pouco, só depois que eu fiz alguns, com imagens minhas eu digo. Não tinha muita diferença, a autoria não era algo tão importante, a gente fazia a coisa junto, baseada em uma outra imagem. A gente fazia um estêncil, claro que tinha alguma 
coisa de autoria pois você não vai fazer um trompete assim ou assim, então o estêncil em si está sendo criado, então não tinha essa coisa muito "isso aqui é meu e isso é seu" a gente usava tudo junto. Então era como carimbo, eu lembro claramente um pouco antes dele viajar ele vir ao meu atelier e pegar as principais máscaras pichar em papel para ficar com uma cópia, e ele cortou as minhas máscaras, uma cópia das minhas máscaras foram levadas para Nova lorque, quando não, cortou lá. E a gente fez a mesma coisa, tanto que o trio sem as pinups, que a gente [Carlos Matuck e Waldemar Zaidler] não fazia aquelas pinups porque ele tinha a luvinha, a botinha, e a estampa que era um coração de pantera...

$P$ : E o corpo ele fazia à mão livre.

C: Sim. Só que ele tinha uma manha de colocar a luva e a bota na posição. A gente olhava "Porra, Vallauri, legal hein?" e aí ele fazia a figura. E às vezes tinha um óculos que era um stencil, mas ele compunha aquelas figuras... a gente não se metia a fazer aquilo. Primeiro que não era do nosso imaginário, a gente fazia com ele, a gente gostava dos músicos que a gente tinha criado juntos, então a gente continuou a fazer os músicos durante um tempo, eu e o Zaidler, até experimentamos fazer eles sem nada à mão livre, porque a gente era louco por estêncil.

$P:$ Acho que vi foto disso, deles só à mão livre.

C: Não, eles só com stencil. Então as linhas a gente pegava um monte de linha curva e reta e ia fazendo. Ele ficava todo certinho, no estêncil, que era um fascinio da gente. Aí a gente começou a fazer estênceis muito maiores.

$P$ : E na técnica, o estêncil, vocês faziam como, em papel?

C: Cartão sempre. Duplex. Porque o Vallauri começou usando capa de disco, como é famoso, como ele tinha um monte de LP 45 antigos na casa dele, provavelmente por causa do pai e da mãe, eram feitos num cartão bem durinho, bem bom, inclusive determinava o tamanho do que ele fazia, porque ele pegava uma capa de LP 45, que é um negócio quadradinho assim, e abria, e esse retângulo deu o tamanho daquele acrobata, deu o tamanho da pantera, deu o tamanho de vários trabalhos, da luva, da bota, todos são enquadráveis numa capa de disco dupla. Todos, perfeitamente, do tamanho certinho da capa. Então ele foi pra Nova lorque e a gente estava aqui, mas ele voltava de vez em quando, aí que a gente deu início à inserção do graffiti no mercado, vamos dizer assim.

$\mathrm{P}: \mathrm{E}$ como começou? 
C: Começou com gente chamando a gente pra fazer coisas. Primeiro, de graça, amigos e conhecidos falavam assim "tem um muro lá, você não quer fazer?" e a gente ia lá, porque era um muro que a gente podia fazer durante mais tempo sem ficar correndo, apesar de que a adrenalina da cidade é um tesão, é o que move. É o que era legal, mas era gostoso fazer alguma coisa com calma, então a gente fazia. Até que começaram pessoas a falar "olha eu tenho uma loja, eu quero fazer um graffiti assim", e iam muito pro Vallauri, e o Vallauri sempre foi muito comercial, não bobeava né? Porque ele ganhava com isso. $\mathrm{E}$ também tinha o fato de que ele trabalhava com muita estamparia de tecido, e tinha muitos conhecidos no mundo da publicidade, das agências, gente que fazia produção de televisão. Então ele pegava muito trabalho, por exemplo, fazer uma camiseta estampada de promoção de final de ano da produtora Nãoseioquê. E ele tinha muito mais contato no mercado de trabalho do que a gente por ser mais velho, a geração dele já estava inserida, a nossa tava começando. Então as vezes aparecia uma pessoa que tinha uma loja, chamava a gente, e a gente começou a cobrar, começou a ganhar fazendo isso.

P: E era graffiti?

C: Era um outro graffiti, aí a gente fazia uma outra coisa, mas eram muito parecidos. Fizemos muito trabalho parecido nós três, eu, ele e o Zaidler. A gente pegava de três logo.

P: E a questão do suporte, quando você aplica um estêncil em outro suporte, como as madeiras recortadas que você faz.

C: Isso demorou pra acontecer.

$P$ : Mas não é graffiti?

C: Pois é, hoje já fico confuso. Pra mim nunca foi, pra mim é outra coisa. Eu era mais radical ainda, pra mim graffiti era na cidade, não vem me falar que graffiti dentro do museu é graffiti.

P: Sim, sim, sim. Pra mim também não é.

C: Mas você percebe que hoje em dia isso daí ficou muito confuso? A gente discutiu muito isso no Nox [livro que Carlos Matuck fez junto com Leon Kossovitch, Waldermar Zaidler e o fotógrafo Kenji Ota], mas muito, tivemos discussões homéricas, tivemos noites só discutindo esse ponto. Porque realmente chega uma hora que aquilo que você diz que é, é, o que você vai fazer? O cara diz que o que ele tá fazendo é graffiti, vai falar que não é? Quem sou eu pra falar pro cara que não é? Quem é que determina o que é o que não é? Eu posso falar 
"eu não acho que é" mas eu não posso dizer que não é. Não dá pra discutir... o que é que Os Gêmeos fazem? Com a minha cabeça daquela época eles simplesmente não fazem graffiti há muito tempo, a não ser esses que eles vão pichar na rua. Agora aqueles puta negócios gigantes no meio da cidade, contratado, pago, com subvenção daqui e dalí, contrato, museu, um puta esquema de galeria. Porra, se isso é graffiti eu quero ser mico de circo, claro que não é, mas eles acham que é. Eles chama disso. É como você querer dizer que "ah, não sei quem não faz rock. O que os Beatles fazem é outra coisa, não é rock". Mas quando o mercado mete um carimbo naquilo e fala ssim, isso é PÁ, e vai funcionar assim porque isso é bom pra todo mundo, fodeu. Foi cooptado, não tem jeito, eu acho que caminhou muito parecido com a questão do rock. Que surgiu uma coisa bem pesada muito proletária, o tempo inteiro contestatório, como tem o rap hoje em dia, Racionais MCs tão aí, metendo o pau em todo mundo, depois ta dando show em estádio pra 15 mil pessoas, né? É difícil.

P: Todos os movimentos são cooptados, eu gosto de pensar nos exemplos do punk e do hip hop, são movimentos de minorias que foram cooptados por tudo.

C: Tatuagem, tatuagem era coisa de bandido, de marinheiro, agora todo mundo tem uma tatuagenzinha, todo mundo é contestatório, é meio bobo. É triste, eu acho muito triste, mas a humanidade é assim, ela assume. Acopla, assimila, espalha. Essa coisa do que é hoje em dia graffiti o que não é graffiti, eu não sei responder. Eu tinha um discurso pronto, mas eu fui fazer o livro, e se você fica sempre discutindo com iguais você não sai do lugar, quando a gente começou a discutir com alguém como o Leon, mudou completamente a discussão, um cara com um puta arcabouço para discutir coisas, seja lá o que for. Você vai discutir gonzo de porta ele muda a sua maneira de pensar, é outra coisa. Então percebemos essas coisas, mudou e seilá que porra que é, eu não tenho mais um discurso pronto para dizer pra você o que é graffiti o que não é. Pirou completamente.

P: Eu também não vou ter essa resposta.

C: Ninguém vai ter!

P: Uma coisa que eu gosto de separar, é o trabalho que a pessoa faz na rua e o trabalho que a pessoa faz no atelier, em outros suportes para outras funções. Isso eu consigo enxergar, isso tem diferença clara.

C: Sim, mas hoje, o trabalho que a pessoa faz na rua ela assina, tem apoio de alguma maneira, é outra construção mental. Eu acho que a gente fazia não só como uma coisa 
contestatória, não era só isso, porque a gente não era engajado politicamente a ponto de fazer uma coisa toda engajada, contra a ditadura. A gente não tinha essa coragem toda, além do mais a gente não tinha essa cabeça, a gente tava se divertindo, fazendo um trabalho divertido de artes plásticas que a gente se divertia fazendo. Não tinha peso ideológico, eu tinha essa cabeça ideológica de esquerda por causa da minha formação, mas ela não se manifestava nesse trabalho.

P: Então vou te contar porque eu separo pichação de graffiti, eu estou separando, a princípio, pode mudar. Tem essa primeira geração que são vocês, e também esse pessoal um pouco posterior como Rui Amaral, o pessoal do tupinãodá, entre outros, e aí tem a galera que faz seguindo a tradição nova-iorquina, que veio através do Hip Hop, e eles já sabiam que eles queriam fazer aquilo, daquele jeito que eles estavam fazendo lá fora já com um estilo definido, o graffiti wildstyle, as letras, as bolhas, contorno, etc.

C: Que é a época áurea, o graffiti do metrô de Nova lorque. Emblemático. Acho que é uma das coisas mais interessantes.

P: Você já viu Style Wars? É um documentário da época muito interessante, do começo dos anos oitenta, é do Henry Chalfant.

C: É aquele cara que fotografava na época?

P: Sim, e o documentário é muito bom, que ele fala exatamente, todo o processo foi através dos trens. Porque chama guerra de estilo, porque o cara aqui no Bronx, faz um puta letreiro foda e manda lá pra longe, os caras lá de longe olham aquilo e falam "vou quebrar esse cara, vou fazer um melhor que o dele".

C: O metrô é o correio, o correio do desafio.

P: Isso, e o cara vai lá e quer fazer melhor, e essa coisa que foi se desenvolvendo a partir do agonismo dos caras, de "eu vou fazer melhor do que ele".

C: Aqueles graffitis lá eu gosto de tudo, da letra, da imagem, da junção da imagem com a letra. Da maneira como eles incorporam o trem no trabalho, é do cacete.

P: E porque eu falo escrita mural, pintura e escrita mural. Porque para esses caras, por exemplo, o principal é a letra. Eles se chamam de escritores de graffiti.

C: É eu sei, writers né? 
P: Graffiti writers.

C: Então, mas eles fazem muita coisa com imagem.

P: Fazem mas...

C: Aí que o negócio fica complicado, porque aquela letra é uma imagem. Os caras trabalham a letra plasticamente, eu acho que eles estão errados infelizmente. Eu não consigo separar.

P: Mas aí é que tá, a figura veio depois, a figura é auxiliar. O cara faz o Manda-Chuva ao lado da letra, mas é só pra chamar um pouco de atenção, só pra dar uma zoada.

C: Mas uma hora fica muito interessante.

P: Mas uma hora, eu acho que foi no decorrer dos anos noventa, a figura foi ficando mais importante que a letra, aí começa isso que começaram a chamar de arte urbana, etc.

C: É que mistura um pouco com aquela coisa mural né, que não era graffiti.

P: A pintura dos chicanos.

C: Dos Chicanos em Los Angeles, e não era só em Los Angeles não, tinha outras pessoas também, e tinha o movimento muralista. Era forte, mais forte nas comunidades, mas era forte de qualquer forma. Eu tenho livros aí.

P: Esse pessoal do meio pro final dos oitenta, mais pro final, começou a fazer aqui o estilo nova iorquino, e é isso que eu chamo, por enquanto, da segunda geração. De outra geração, porque a matriz é outra, é outro referencial.

C: Pode ser, pode ser mesmo.

P: E outra diferença que eu enxergo clara entre vocês, é que vocês, da sua geração, já tinham um arcabouço artístico.

C: Ah, claro.

P: E esse pessoal, eles não estavam interessados em arte, eles estavam interessados em graffiti.

C: Eu sei, o que de certo ponto de vista é uma vantagem. 
P: Sim, mas depois de um tempo eles começaram a ficar limitados pelas regras internas do graffiti e começaram a buscar outras coisas.

C: Mas aí o mercado abriu os caras, aí virou uma coisa... é outra coisa eu acho.

$P$ : Mas inicialmente, ao menos com as pessoas que eu conheço, que eu conversei, essa primeira pulsão, de "vou fazer a coisa do meu jeito" veio da força dessa disputa interna. Dentro do graffiti "eu estou cansado de fazer isso igual a todo mundo, eu vou fazer do meu jeito", aí cada um foi fazer sua pesquisa, tem o Speto por exemplo, ele começou a fazer as coisas do estilo dele porque ele pegou um referencial de xilogravura.

C: Muito bonito o trabalho dele.

P: Aí ele faz só com preto e branco e vai recortando.

C: Muito bonito, e tinha uma cara de xilogravura tão legal, parecia a sobra da madeira que você não conseguiu cortar.

$P$ : E vem da técnica do spray, mas isso eu acho que ele começou a desenvolver pro final dos noventa, que antes era wild style, hip hop como a maioria deles, mas enfim eu separo através dessas matrizes, e pichação paulista é outra coisa.

C: Então, aí tem outra história aí, que está cada vez mais complicada de entender. O que chamam de agenda, essa maluquice total, que pra gente é completamente estratosférica, o respeito, não atropelar. Para nós atropela era o que era legal, eu falo isso pra eles e ficam me olhando com uma cara estranha, mas eu falo "escuta, a coisa mais legal é o atropelo".

P: Por que?

C: Porque cria uma terceira dimensão no trabalho, que não é mais de ninguém, e justamente ele não é de ninguém, ele é da cidade, ele faz parte daquela parede ele não é mais seu ou meu ou de não-sei-quem, é da cidade inteira. Era legal, era vivo, a parede vai mudando, a parede tem uma vida própria, esse negócio de ir lá e comprar a parede, eu falei disso com o Speto, que foi naquele seminário no MASP.

P: Eu estava lá.

C: Eu falei "porra, mas, caralho, você vai lá dizer 'essa parede é minha' sobre uma parede que é de outra pessoa, de um terceiro, você fala lá 'ah aqui só eu vou pintar"' você lembra dele falando? "Não, mas tem um investimento, a pessoa gasta uma grana" porra, e daí que gastou uma grana pra fazer isso, lógico, se não, não faz, ta dentro do esquema. Agora você 
falar "isso daqui eu que fiz, tem que respeitar" numa parede que não é dele... Eu só entendo isso se for a parede da sua casa, agora a parede de terceiro pra mim é totalmente pinel, pra eles não é!

P: Pois é, mas é aí que tá, na pichação paulistana, se você fizer um picho e colocar lá a data 89 , quanto mais velha ela ficar mais valor ela tem. Tem o valor da idade.

C: Mas qual valor?

P: Pra eles tem, o valor de quanto tempo a coisa está lá.

C: Valor de antiguidade.

P: O valor da antiguidade, o valor de ser o precursor "olha lá, aquele pixo eu fiz em oitenta e nove, e está lá até agora". Pra eles tem um valor importantíssimo isso, assim como o valor da altura, o cara escalar um prédio para fazer um pixo.

C: Eu entendo essas pirações, é totalmente estratosférico pra mim mas eu entendo. Eu acho que essa que foi empobrecedora, embora eu saiba que o cara faz um trabalho digamos, do ponto de vista intelectual das artes plásticas, um trabalho fechado, não aberto, o nosso era aberto, fazia uma coisa ali outra aqui mesmo que houvesse um monte de figura ficava um monte de buraco pra você entrar, tanto é que as pessoas entravam.

$\mathrm{P}:$ E era legal?

C: Era porra, tem graffiti que os pixadores vinham fazer uns negócios e ficava muito interessante, uns caras que a gente nunca vai saber quem foi, e ficava interessante, a gente curtia pra caramba. Tem um que eu acho clássico, um dos que eu mais gosto, típica daquela época, do final do nosso graffiti, isso é 83 e 84, que era a pinup com um frango e eu fazendo uns cachorros todos tortos e os caras vão lá e fazem um balão enorme dizendo "HUMANOS! HUMANOS!" todo mundo tá dizendo "HUMANOS!". A gente comemorava essa participação, a gente ia lá fotografar de novo, porra, os caras fizeram um negócio genial.

$P:$ É que o de vocês era aberto, depois virou fechado.

C: Então, aí virou mural.

P: Sim.

C: Aí chega o cara e diz "isso aqui é o meu trabalho, eu tive um investimento" tinha gente que não achava que era certo e entravam, aí os caras ficavam putos. O Rui [Amaral] por 
exemplo toda vez que pichavam o negócio dele na Avenida Paulista ficava louco da vida. E aquele fica num limite, eu acho que tem uma abertura para pichar, ele não é tão fechado.

$\mathrm{P}:$ Visualmente, não.

C: Então, isso que eu estou falando, e o cara fica puto do mesmo jeito acha um absurdo. Depois ele fez aquele puta negócio enorme lá na Paulista, aí tudo bem, aquilo é um mural.

$\mathrm{P}:$ Aquele na parede cega do prédio?

C: Isso, aquele robozão, mas isso é recente, é de agora, isso é pós ascenção mercadológica. Mas aquele outro não, aquele chama, e eu ficava "Porra Rui, mas ta cheio de pichinho seu lá, você não acha que o cara vai querer entrar?" eu não sei.

P: Aquele bando de espaço vazio, azul, dá vontade de dar uma pichadinha.

C: Não é? Então. Mas eu sempre olho as coisas, eu vejo o beco do batmam e pra mim ta tudo aberto, eu não consigo ver nada fechado alí.

$P:$ Não consegue ver fechado?

C: Não, não consigo, aquilo é um beco, cheio de coisa pintada por todo mundo, como é que pode ser fechado, como pode achar que ele reservou aquele espaço. Tira toda a graça, fica uma coisa sem graça.

$\mathrm{P}$ : Acho que virou uma coisa mais sisuda mesmo.

C: Então, mas virar uma coisa sisuda esse tipo de manifestação para mim é muita perda. É mais ou menos como fazer um disco do Paul McCartney com a orquestra sinfônica de Londres, fica aquela coisa que não é nada, o cara faz rock, o cara é roqueiro, não é um músico da universidade, não é um Berio [Luciano Berio], tá longe, então vai lá e faz aquela coisa que é horrível. É híbrida, é feia, fica bobo, fica uma coisa sacralizada que não é sacralizável, então pra mim perde a graça. Na cidade perde toda a graça, se fosse uma coisa específica, por exemplo, uma parede inteira de um lugar como os gêmeos fizeram depois, é um negócio inteiro, aí eu acho que fecha. Fecha em todos os sentidos, fecha como mural, pode chamar de graffiti se quiser, tanto faz, mas fecha no sentido urbano, no sentido artístico. 
P: Faziam muito isso uma época, acho que no começo dos 2000, tinha uma galera o Vitché, o Cobal, os Gêmeos, o Tinho, eles até fazem isso ainda, de pintar quatro pessoas um mural juntos, e o desenho de cada um conversando. Perdeu um pouco isso.

C: É do caralho, é uma pena, é uma perda.

$\mathrm{P}$ : Vou te contar um causo muito interessante, você conhece o Onesto?

C: Claro.

P: Então, eu fiz uma entrevista muito boa com ele para a minha pesquisa. Eu estava falando com ele sobre a questão do atropelo e tudo mais e ele me disse uma coisa "teve uma época que era muito ruim de pintar na rua, na gestão Erundina" justamente porque não apagavam nada.

C: Que ótimo isso, muito bom.

P: Não dá espaço para respirar, tá tudo tomado então você não faz nada. Precisa limpar pra renovar, para ter força.

C: Então, chegamos ao ponto, vai lá Os Gêmeos numa esquininha que não é nada na cidade, e faz uma coisa lá, e passa a prefeitura e apaga, e os caras ficam putos. Falam "vocês estão apagando a cultura Brasileira!".

P: Então, é que essa artificação artificial do graffiti eu acho muito curiosa, deixou de ser essa coisa gostosa e divertida para virar algo sisudo. E tem outro fato recente, teve um mural que teve apoio da prefeitura num desses túneis a Dr. Arnaldo à Rebouças eu acho.

C: Aí os caras da medicina foram lá.

P: Aí foram os caras da medicina lá apagaram tudo de preto fizeram sua caveirinha com sua cartola e sua piteira.

C: Só por causa da festa!

P: Só por causa da festa, mas aí você pensa "porra que desrespeito com os grafiteiros".

C: Não é desrespeito coisa nenhuma.

P: Pois é só porque tem apoio da cidade, da prefeitura, é do público, é de todo mundo. E aí vem uma coisa que eu questiono, há quantos anos os caras não fazem isso? Os caras da 
medicina, não é de hoje, já é uma tradição, eles tem a festa todo ano eles vão lá e apagam tudo com preto e fazem uma caveira, bom, ótimo.

C: Então, mas agora é tudo profissionalizado.

$P$ : Eu não quero andar num museu curado pela prefeitura.

C: Aí fica aquela coisa tonta, aquela divisão escolar. O Joãozinho pintou esse, o Pedrinho pintou esse.

FIM DA GRAVAÇÃO 


\section{Entrevista 3:}

Entrevista com Onesto concedida em 9 julho de 2014.

Pedro Moreira Graça: Que ano você começou a pintar?

Onesto: Comecei logo por ali, 91, 90, já fazia uns rabisquinhos. Mas quando comecei a ter contato mesmo com a coisa foi mais final de 91 pra 92.

P: Já em 92 você já participou dessa exposição no MIS?

O: Sim.

P: Você acha que foi muito forçada essa mudança de suporte?

O: Pra mim não tinha nada a ver, eu comecei a fazer graffiti porque tinha a possibilidade de utilizar a rua pra disseminar uma ideia. Enquanto que os caras que você falou, do estêncil, já gostavam disso, de ver o trampo deles dentro de um quadro, de um espaço.

$P$ : De uma instituição, de uma galeria.

O: Achei zoado, ainda mais que a disposição das obras era uma em cima do outra. Mas rolou, aí depois eu neguei mais e demorei para aceitar outra exposição por que eu queria entender o que eu podia fazer para estar lá no espaço deles. Não queria colocar uma coisa que eu faço na rua dentro.

$P$ : Isso é um problema que eu vejo muito claro de um cara que tem um trabalho de rua, dele mudar para um espaço de dentro. Não é simplesmente você pegar o trabalho que faz na rua e mudar o suporte que vai fazer um trabalho bom. É uma coisa muito complicada para mim.

O: Não funciona, você faz um trabalho que é pra rua, você coloca ele num suporte que fica lá preso, as pessoas vão ter que ir pra ele. Quando eu faço o meu personagem passando de carro você vai ver que é ele.

$P$ : E também outra coisa, tem muito grafiteiro que faz um personagem mas não é tão comum no graffiti pintar um fundo para acompanhá-lo.

O: Total. 
$P$ : $E$ isso num suporte de dentro é muito complicado, você não vai pegar um personagem e colocar em uma tela branca porque vai ficar feio, não tem uma profundidade, aquilo na cidade é uma coisa, dialogando com tudo o que tem na parede, com toda a arquitetura, com toda a rua, agora você colocar aquilo no papel, em uma tela, fica muito estranho.

O: É, eu comecei a entender melhor isso quando comecei a ler sobre um artista que eu gosto pra caramba, que é o Barry McGee. Ele falava que graffiti é performance, é como você faz não o que você faz, o como você faz as coisas é que tem essa força que pode chamar graffiti. Tanto é que tem esse video que eu fiz que chama Objetos Nulos.

P: Você acha que parte do graffiti e da pichação é pegar esses espaços e chamar atenção para a cidade?

O: Total. Porque muda o lugar, se você coloca um personagem uma letra o que quer que seja, se o espaço tá abandonado você chama a atenção para aquele espaço. Então eu acho que quem entende essas coisas consegue ter um trabalho mais forte, chamar mais atenção. Tanto pro bem quanto pro mal.

P: Você acha que tem lugar errado pra fazer graffiti?

O: Não existe, qualquer lugar é certo. Depende do que o cara quer fazer, como o cara quer se mostrar pra cidade, pras pessoas.

$P$ : Eu te falei que eu estou gostando muito do extintor, e eu acho que ele não liga em ser bonito. Eu acho muito interessante que muitas vezes não dá pra identificar o que está escrito, até pra quem tem o olho treinado pra graffiti e pichação não entende o que está escrito.

O: A primeria vez que eu vi foi em São Francisco, faz tempo pra caramba, acho que 2007, a minha primeira exposição. É muito foda ver o bagulho todo escorrido gritante, todo tremido que você não tem um controle. É uma ferramenta a mais que veio pra fazer a coisa. Você conhece o artista KR? Ele usa o extintor pra fazer o trampo dele mas a estética dele é deixar escorrer, com várias ou uma cor.

$P$ : Mas ele veio também de uma tradição de arte urbana, de graffiti?

$\mathrm{O}$ : Ele começou colocando o nome dele $\mathrm{KR}$, fazendo grande, pequeno, tag pra caramba. Mas quando ele viu a escorrida do extintor, só escorrer já era uma identidade. 
P: E quando você começou a fazer graffiti, lá por noventa, noventa e um, você pegava que referências? O pessoal de nova iorque mesmo? Eu lembro que já conversamos que você conhecia já o pessoal que fazia graffiti antes desse estilo de nova iorque vir, do estilo de graffiti americano vir pra São Paulo, você ja conhecia o trabalho do pessoal do estêncil mas não se interessava tanto por ele, você começou a se interessar pelo graffiti de estilo nova-iorquino, como foi esse começo esse interesse?

O: Como na época eu era office boy e andava bastante pelo centro eu já via um estêncil aqui outro ali, mas não me chamava tanto a atenção como quanto eu via trabalho do Speto dos Gêmeos, que era uma coisa mais de desenho, que a estética era muito atrativa tinha letra, setas, estrelas, tinha todo um envolvimento que me chamava a atenção. Enquanto o estêncil era uma coisa mais fria eu achava, reproduzia uma imagem e a composição não era tão interessante.

$\mathrm{P}$ : Também pelo fazer à mão do graffiti?

O: Isso, eu ficava interessado em como o cara controlava a pressão do spray, faziam aqueles traços. Eu achava louco que quando tinha um evento, os caras do estêncil, os caras do spray can que faziam as coisas à mão livre, o pessoal do stencil meio que sumia no meio do muro. Tinha um muro, os caras pegavam cada um o seu espaço mas os caras não se destacavam, e eu comecei a analisar isso, o porque né? Aí eu comecei a achar as letras mais interessantes.

P: Aí você começou mais pela letra?

O: Quando eu comecei a fazer graffiti, eu coloquei na minha cabeça que eu tinha que primeiro a aprender a fazer algumas letras decentes primeiro para depois ir para 0 personagem, por mais que eu já desenhasse personagens desde pequeno, acho que letra é o fundamental. Isso que é fazer graffiti.

$P:$ Você pode me explicar um pouco o que é a letra e o que é o personagem no graffiti?

O: Cada um tem o seu entendimento sobre a coisa, na minha concepção a letra é para você fixar o seu nome no espaço. O personagem é apenas um complemento para chamar a atenção, para deixar aquele trabalho mais interessante, para criar uma composição.

P: Então na sua visão no graffiti o mais importante é a letra e o personagem seria auxiliar, para chamar a atenção do público em geral para aquela letra? 
O: Sim, porque os caras começaram a ter mais habilidade e a fazer personagens mais interessantes mas a ideia no começo era você criar o seu estilo de letra, totalmente único, e o personagem você pegava qualquer coisa, pegava um de historia em quadrinho pegava de uma revista que você via.

$P:$ v você começou a fazer assim também os seus personagens?

O: Não, como eu já desenhava desde pequeno eu sempre tive não necessariamente meus personagens, mas tinha uma ideia, uma direção, eu tinha um diferencial já.

P: Você não pegava então um personagem de história em quadrinho por exemplo?

O: Não, eu nunca precisei copiar nada, mas eu estudava bastante, comprava bastante gibi, era viciado em comics na época, e assim eu fui criando meu próprio estilo, puta, eu achei legal a perna desse cara, fazia um frankenstein e fazia o meu, mas depois de um tempo mudou. Os caras começaram a aprimorar muito em personagem, desenho realista, mesmo no abstrato, e as letras foram ficando, não diria para trás, mas marcaram bem o que era graffiti e o que é Street Art. É daí que veio essa divisão.

P: Você acha que é daí a divisão?

O: Aham, Street Art ficou com coisas mais figurativas.

P: A única definição que eu achei mais ou menos razoável é do Cedar Lewisohn, que escreveu o Street Art: The Graffiti Revolution, ele fez uma exposição no TATE, chamou o Nunca. Ele dá a seguinte definição entre graffiti e street art: Graffiti é uma linguagem interna aos praticantes do graffiti, mais voltada para eles, do que o Street Art que é feito, é voltado para um público em geral.

O: Funciona.

P: Pra mim é um termo que funciona.

O: Pra mim ele entendeu bem a coisa, porque não é todo mundo que entende um Wild Style, um Piece que às vezes é simples pra quem faz graffiti, mas pra quem é leigo diz, não tá escrito nada nisso aí, não é nada.

P: Sim, ver um throw up de bolha é normal o cara não entende nada. Esse throw up aqui ó [aponta para um graffiti à vista] não é todo mundo que consegue ler, eu não estou conseguindo aliás. [Risos] 
O: E aqui em São Paulo tem essa nova geração que tem uma estética totalmente louca, isso aqui eu também não entendo tenho que analisar lá pra ver o que tá escrito.

P: O que eu acho curioso é que tem uma galera grande que continua fazendo graffiti tradicional, ao estilo de nova iorque, letra e personagem.

O: Acho que todo mundo. Até eu faço letra de vez em quando, é a base, sabe?

P: Estava falando de uma galera que continua fazendo wild style por exemplo.

O: Aham.

$\mathrm{P}:$ Você faz wild style às vezes?

$\mathrm{O}$ : Às vezes eu faço, bem raro mais ainda faço.

P: É legal voltar pra base?

O: Não é nem uma volta, é uma coisa de você não querer se preocupar. É como cantar uma música que você já tem ela decorada na cabeça, você não quer ficar pensando, estudando, não, você está com seus amigos, está se divertindo, você vai lá e faz uma parada, testa outras coisas também, e se diverte. Não é voltar, não é regredir, também não é querer afirmar "Não, eu sou grafiteiro! Eu sei fazer isso!". É gostoso, é como andar de skate e ficar só dando ollie ${ }^{77}$, não precisa ficar dando manobra complicada, só pular algumas coisas é legal.

P: Você chegou a pichar alguma hora?

O: Nunca pichei, mas adoro a estética. Hoje até treino umas letras, faço umas doideras às vezes, agora eu estava com uns amigos fiquei fazendo um dos meus nomes que é letra de pichação, só porque estava com eles e eles picham. Mas sair mesmo "Hoje eu vou sair pra pichar" sempre acaba saindo alguma coisa mais complexa, ou throw up, seila, sempre tive na minha cabeça que conforme eu for sair pra rua eu quero ser diferente, não quero fazer algo semelhante, algo parecido.

P: Isso é uma coisa que eu acho muito importante que eu vejo no graffiti desde o começo, até vendo coisas como o Style Wars, você vê que é muito importante para o grafiteiro fazer

${ }^{77}$ Ollie é uma das manobras mais básicas no skate de rua, quando o skatista bate com a parte de trás do board no chão para se projetar em um salto. 
um trabalho melhor do que o oponente dele, do que o outro grafiteiro. E esse jogo, essa briga é o que faz a coisa se desenvolver, ficar mais complexa, mais rica.

O: E hoje perdeu um pouco disso, isso que dá raiva.

P: Por que você acha que perdeu?

O: Tá todo mundo muito amiguinho "Ai, não vou atropelar ele. Ah, não vou fazer melhor que ele, vou fazer aqui do lado". Aí o negócio vai decaindo né?

P: Sei. Porque pra mim uma das forças principais para o desenvolvimento do graffiti é esse agonismo "eu vou fazer melhor que você sim", querer superar o próximo.

O: Sempre acreditei nisso, isso que fazia a coisa ficar divertida, você saía pra rua pra quebrar o cara que tá saindo junto com você, pra quebrar o cara que você viu. Hoje não todo mundo, "ai não vou fazer nada ali".

P: Tá todo mundo muito educado?

O: Muito bonzinho.

$P: E$ você acha que afeta a técnica deles, por que não cresce?

O: Muito. De 2000 pra cá são poucos artistas que surgiram, coisa nova coisa diferente, coisa instigante, você olha e: "Caralho, olha o que o cara tá fazendo, preciso dar um gás aqui, porque estou ficando pra trás". Tá tudo muito nivelado.

P: Ou o cara começa a fazer de um jeito tão diferente, que não tem um espaço comum para ter essa briga, você vê isso?

O: Eu não vejo isso.

P: Você não vê nada tão diferente?

O: Não. Uma que os caras já começam com uma ideia de "Ai, eu vou ser artista" não tá fazendo graffiti.

P: Então você acha que hoje em dia já começam mais preocupados com arte do que com graffiti.

O: Total, ninguém mais tem a ousadia ou a predisposição pra sair na rua e sair fazendo graffiti, o cara quer conforto, "vou fazer ali porque está autorizado, o cara já deixou, vou 
ganhar uma grana com isso". Agora são poucos que saem pra bombardear, deixar algo diferente na rua, que fazem porque amam ou por prazer.

$\mathrm{P}$ : E você acha que antes isso era muito mais comum, nos anos noventa era outra história? O: Total, não tinha esse glamour, esse tapinha nas costas "Oh, parabéns pelo que você está fazendo aí". Você tinha que se virar, fazer um negócio legal, fugir da polícia.

P: E fazer seu corre e fazer muito, fazer um trabalho melhor do que o outro pra ter reconhecimento.

O: Isso ajudava a ter melhores artistas, hoje não, o cara sai colando um papelzinho na rua e fala que tá fazendo graffiti. Um bonequinho de bolinha e tal. Perde muito. Aí o Street Art, o graffiti, seja lá o que for, só perde com isso. Mas tem muito cara bom surgindo aí, eu vejo muita gente boa nas periferias, quando eu vou pintar longe eu vejo. Os caras não tão interessados em vir pro centro, ficar disputando espaço, porque todo mundo quer estar aqui, esses caras não, eles ficam lá no cantinho deles fazendo um trampo legal. E hoje com internet também. Os caras colocam onde eles quiserem, não tem mais essa coisa de esperar um retorno "Puta, eu queria conhecer um cara que mora lá na zona tal" com a internet você vai lá e já era, marca um rolê com o cara.

$P:$ A internet ajudou muito nesse sentido você acha?

O: Ajudou a disseminar a ideia, a propagar, a divulgar, mas atrapalhou pra caralho também.

$P:$ No que?

O: Porque hoje qualquer um faz um negocinho na parede, tira uma foto, põe na internet e fala que é o cara. Isso é péssimo e já tem.

P: O famoso grafiteiro de fotolog.

O: Ou de facebook, instagram. Não dá pra ficar julgando muito porque também é outra geração, eu por exemplo tenho quarenta anos. Os caras que tão fazendo isso hoje tem seilá, 20, 15, 18, 25. É outra forma de assimilar as coisas, informação, eu me matava pra achar graffiti quando eu comecei, hoje os caras trombam com graffiti. Mesmo sem querer ver você vê. 
$P$ : Isso é curioso eu queria entender um pouco como é essa coisa de você querer fazer graffiti no estilo nova-iorquino, já tinha um pessoal fazendo isso, como era essa escassez de material de referência para vocês?

O: Acho que era até legal, porque você conseguia criar algo original, você não tinha a referência, você não tinha a base, aí você ia por outros caminhos.

P: Mas a base você tinha? Sabia o que era um bomb, um throw up?

O: Não, a gente achava que tudo era graffiti. Não tinha essas nomenclaturas.

$P:$ Nem de técnica, de fazer o outline depois preencher?

O: Não, a gente via, achava legal e tentava fazer, mas não sabia o que era. Aí quando vinha alguém que viajou, conheceu alguém lá fora ou veio um gringo pra cá e explicou você falava "Aaaahhh".

P: Mas quando vocês sacaram esses termos essas técnicas vocês já pegaram elas pra vocês?

O: Não de imediato, porque a gente já estava meio condicionado. Não tinha spray bom, tinha que se virar com o que tinha. Látex rendia muito mais porque você não tinha grana pra ficar comprando spray, você já tá condicionado, já tinha o seu arsenal alí. Aí pra começar a pegar essas coisas de fora demorou um tempo.

$\mathrm{P}: \mathrm{E}$ você acha que latex é uma coisa mais brasileria mesmo?

O: Total. A gente não tinha como pintar só com spray. Os gringos não, eles zeram uma parede de uma cor e vem tudo com spray. Aqui não, você preenchia a letra, o personagem, com as cores que você queria e o spray só era contornar e olha lá, que ainda tinha que sobrar pro rolê seguinte. Era bem suada a coisa.

$\mathrm{P}:$ E tudo colorgin? ${ }^{78}$

O: Infelizmente né? [risos] Colorgin e umas piores ainda que eu nem lembro a marca. Hoje um cara já começa com uma Montana, outra coisa, começa com vários tipos de bico diferente, tem desde o fino até o extra gigante.

$P$ : E vocês só tinham o padrão do colorgin?

\footnotetext{
${ }^{78}$ Marca de spray nacional.
} 
O: Só tinha aquele alí e se vira, e pra descobrir que tirando a pressão da lata saía mais fino, puxando o bico pra trás.

$P:$ vocês descobriam isso sozinhos?

O: Na raça. Não tinha cor também, a gente tinha que inventar as cores, deixar a lata na geladeira pra abaixar a pressão, depois você pegava o bico de um lubrificante.

P: WD-40?

O: Acho que é esse daí, colocava uma lata de ponta cabeça e a outra de pé e misturava as cores e ficava testando. Era outra vida.

$P$ : Certa forma isso enriquece bastante o repertório que vocês tem?

O: Claro, é pesquisa. E é isso que os caras de hoje não tem, os caras vão lá na graffiti shop com o papai e fala "pô, quero esse, esse, aquele", papai assina o cheque, "vai filho, faz aí". Aí sai bosta, não tem pesquisa. Só quando o cara é muito talentoso né, e não tá acontecendo muito disso aí não.

$P$ : Isso sempre, às vezes tem gerações que são melhores mas...

O: É louco tudo isso, acompanhar tudo isso. Eu fico pensando se eu tivesse começado ano passado a pintar, se eu ia refletir tanto sobre essas questões ou se "foda-se, eu quero só fazer e pronto". Hoje você chega em um muro, começa a pintar, ninguém vem tirar satisfação, no máximo pergunta o que você tá fazendo, você inventa uma história ou pede mesmo pro dono, de boa. Antigamente? Ave maria.

P: E esse lance da cidade limpa de apagar pichação e deixar graffiti.

O: Apagar pichação e deixar graffiti eu acho zoado, não tem a ver, ou apaga tudo ou não apaga nada. Como teve uma época, acho que na gestão Erundina [prefeita de São Paulo de 1989 a 1993], que não apagava nada, não tinha mais espaço pra pintar.

P: Aí era ruim também?

O: Aí era péssimo, era muito foda, um pico maior legal...

$P$ : Isso é muito bom, ninguém me contou isso ainda.

O: Um lugar que você sonhava em pintar mas já tinha um monte de coisa alí. Quando zeraram aí foi a festa, todo mundo pintando. 
P: Isso que é curioso do graffiti. Ele vai acontecendo, ele precisa ser renovado de hora em hora.

O: Total, tem que. Eu acho que essa coisa de que graffiti tem que ser pra sempre, aquele muro é meu, não existe. Apagou? Quem chegar primeiro toma.

P: Mas e coisas como aquele museu ao ar livre em Santana?

O: Aquilo é um projeto, é outra coisa, não é mais público, já tem uma ideia formada alí. Tem curadoria, os caras ganham para pintar naquele espaço.

P: Você acha interessante?

O: Ahh...

P: Você acha bom?

O: Bom? Eu não gosto, eu participei da primeira edição pra ver qual que era, eu sou assim, eu faço uma vez se eu não gosto, nunca mais. Aí me perguntaram se podia apagar o meu daqui a um ano, dois, eu falei "Demorou, pode apagar daqui a um mês". Não penso que o graffiti é uma coisa pra sempre, se fosse pra sempre eu pinto uma tela, aí eu sei que tem normas museológicas, vai ser conservado, os caras tem que preservar, beleza. Agora tá na rua, pode vir um tufão, acabar com a casa, chuva, sol, não tem essa. Então não sei, deve ser bom pra algumas pessoas aquilo, pra mim não serve, se me convidarem de novo pra ir lá eu nego. Só se for um formato diferente, uma proposta, "não agora você pode usar dinamite pra fazer o que você quiser" aí é legal, fazer uma outra coisa. Agora ir lá e pintar de novo, "toma essa graninha aí", não, prefiro pintar em qualquer lugar na rua. E tem gente que vai atrás hoje da divulgação, da superexposição, entrar nas mídias. Eu nunca achei que graffiti fosse isso, por isso que eu tentei me omitir ao máximo, mas chegou uma hora eu pensei: "Meu, se tá todo mundo tirando alguma vantagem disso eu também posso tirar. Não preciso ir no mesmo caminho que eles, mas eu posso fazer a minha também". Tanto que eu tento fazer as minhas coisas sem ficar tão exposto, eu tento preservar algumas coisas que eu acredito, tanto é que quando eu uso [o nome] Alex Hornest, quando eu estou na rua eu uso Onesto, pra galeria museu eu tenho tempo de fazer trabalhos mais elaborado, não é em quinze, trinta minutos como eu faço na rua. Eu pesquiso mais. Eu tento preservar as coisas que eu acredito, que servem pra rua, que fazem a rua ser o que ela é. Não sei se eu estou certo, mas pelo menos eu me sinto bem quanto a isso, eu não fico frustrado eu não fico sofrendo. Teve uma época que eu sofri muito, "Que merda que eu tô fazendo, por que eu 
continuo fazendo essa bosta? Por que eu to indo pra galeria? Por que eu to pintando na rua?" Vários conflitos. Agora não, agora zerou, me divirto na rua pra caramba, me divirto quando eu faço exposição em galeria, hoje eu entendo que são coisas diferentes.

P: Mas demora né?

O: Demora, você precisa se entender né? Se posicionar, ir só no oba-oba é fácil, agora você tomar partido de umas coisas, acreditar, defender.

P: Bom, só pra deixar claro. Graffiti é na rua, dentro de galeria, exposição, é outra coisa?

O: Quando eu vou numa exposição e os caras falam que é graffiti, street art, eu já entendo que não é isso, alí o cara está usando a estética do graffiti, graffiti só funciona na rua, tem que ter todo esse agito, a poluição, as complicações. Alí dentro é muito confortável não dá pra falar que é graffiti. O cara tá usando uma técnica, fazendo graffiti não.

FIM DA GRAVAÇÃO 